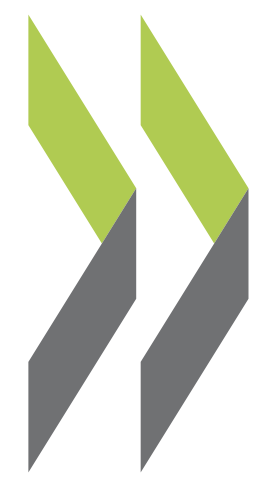

OECD Economics Department Working Papers No. 1201

Effects of Economic Policies on Microeconomic Stability

\author{
Boris Cournède, \\ Paula Garda, \\ Volker Ziemann
}

https://dx.doi.org/10.1787/5js3f5cwj3jb-en 
Organisation de Coopération et de Développement Économiques

Organisation for Economic Co-operation and Development

01-Apr-2015

ECONOMICS DEPARTMENT

English - Or. English

\section{EFFECTS OF ECONOMIC POLICIES ON MICROECONOMIC STABILITY}

ECONOMICS DEPARTMENT WORKING PAPERS No. 1201

By Boris Cournède, Paula Garda and Volker Ziemann

OECD Working Papers should not be reported as representing the official views of the OECD or of its member countries. The opinions expressed and arguments employed are those of the author(s).

Authorised for publication by Jean-Luc Schneider, Deputy Director, Policy Studies Branch, Economics Department.

All Economics Department Working Papers are available at www.oecd.org/eco/workingpapers

JT03373500

Complete document available on OLIS in its original format

This document and any map included herein are without prejudice to the status of or sovereignty over any territory, to the delimitation of international frontiers and boundaries and to the name of any territory, city or area. 
OECD Working Papers should not be reported as representing the official views of the OECD or of its member countries. The opinions expressed and arguments employed are those of the author(s).

Working Papers describe preliminary results or research in progress by the author(s) and are published to stimulate discussion on a broad range of issues on which the OECD works. Comments on Working Papers are welcomed, and may be sent to the Economics Department, OECD, 2 rue André-Pascal, 75775 Paris Cedex 16, France.

Comment on the Papers is invited, and may be sent to OECD Economics Department, 2 rue André Pascal, 75775 Paris Cedex 16, France, or by e-mail to eco.contact@oecd.org.

This document and any map included herein are without prejudice to the status of or sovereignty over any territory, to the delimitation of international frontiers and boundaries and to the name of any territory, city or area.

\section{(C) OECD (2015)}

You can copy, download or print OECD content for your own use, and you can include excerpts from OECD publications, databases and multimedia products in your own documents, presentations, blogs, websites and teaching materials, provided that suitable acknowledgment of OECD as source and copyright owner is given. All requests for commercial use and translation rights should be submitted to rights@oecd.org 


\section{ABSTRACT/RÉSUMÉ \\ Effects of Economic Policies on Microeconomic Stability}

Economic policies shape how much people earn as well as how stable their income and jobs are. The level and stability of earnings both matter for well-being. Standard economic aggregates do not measure accurately the economic uncertainty which households are facing. This paper shows that household-level economic instability is only very loosely related to macroeconomic volatility. It uses several householdlevel databases to document how pro-growth reforms influence household-level economic stability. Movement from less to more productive processes and firms is at the heart of economic growth, which suggests a trade-off between growth and micro-level stability. Certain policy changes boost growth but increase micro-level instability: they include reductions in tax progressivity or social transfers (including unemployment benefits) as well as moves from very to moderately tight restrictions on the flow of goods and services and on the dismissal of regular workers. However, the analysis also uncovers that moving to highly competitive policies generally reduces micro-level instability.

JEL classification: D12; D22; J08; O40.

Keywords: stability, households, economic growth, reforms, microdata.

\section{Effets des politiques économiques sur la stabilité microéconomique}

Les politiques économiques façonnent les revenus mais aussi leur stabilité ainsi que celle des emplois. De fait, le niveau comme la stabilité des revenus tous deux influencent sur le bien-être. Cependant, les agrégats économiques traditionnels ne mesurent pas l'incertitude économique à laquelle les ménages sont effectivement confrontés. Cette étude montre que l'instabilité économique vécue par les ménages n'entretient que des liens très distendus avec la volatilité macroéconomique. Elle utilise plusieurs bases de micro-données collectées au niveau des ménages pour documenter la manière dont les réformes encourageant la croissance influencent la stabilité économique des ménages. Le mouvement vers des processus et des entreprises de plus en plus productifs se situe au cœur de la dynamique de croissance économique : cette observation suggère qu'une tension peut s'établir entre croissance et stabilité microéconomique. Certains ajustements des politiques publiques augmentent la croissance, mais au prix d'une plus grande instabilité micro-économique : il s'agit des réformes qui rendent la fiscalité ou les transferts sociaux (y compris les indemnités de chômage) moins progressifs ainsi que des mesures qui remplacent de fortes restrictions sur la concurrence ou sur les licenciements de travailleurs permanents par des restrictions de niveau intermédiaire. Néanmoins, l'analyse fait aussi apparaître que, lorsque les réformes dans ces domaines sont plus appuyées et conduisent à un niveau élevé de concurrence, elles réduisent le plus souvent l'instabilité micro-économique.

Classification JEL : D12 ; D22 ; J08 ; O40.

Mots-clefs : stabilité, ménages, croissance économique, micro-données. 


\section{TABLE OF CONTENTS}

EFFECTS OF ECONOMIC POLICIES ON MICROECONOMIC STABILITY …....................................6

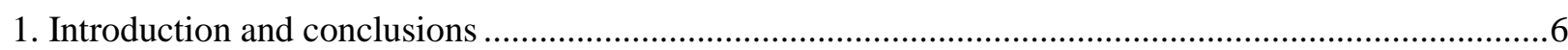

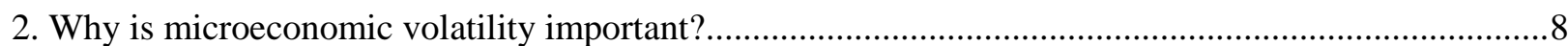

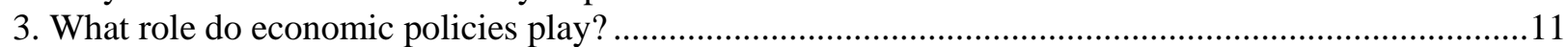

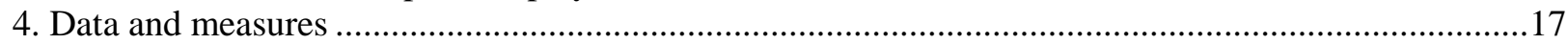

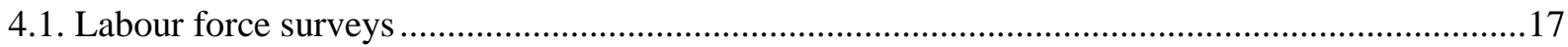

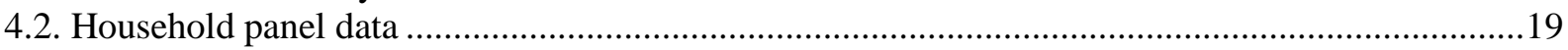

5. The links between economic policies and microeconomic volatility .................................................22

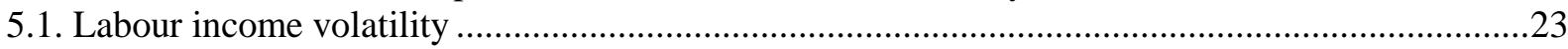

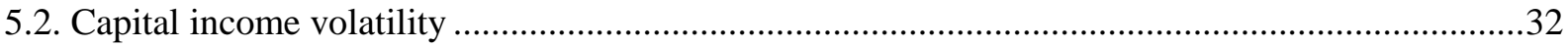

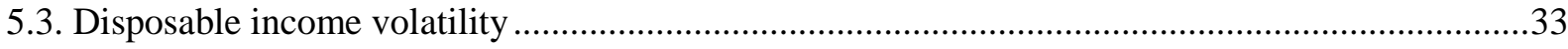

6. Reconciling microeconomic stability, economic growth and inequality ............................................37

6.1. Trade-offs and complementarities between growth and micro-level stability ................................37

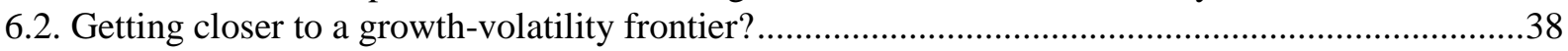

6.3. Trade-offs and complementarities between equity and micro-level stability................................41

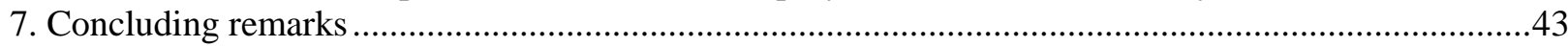

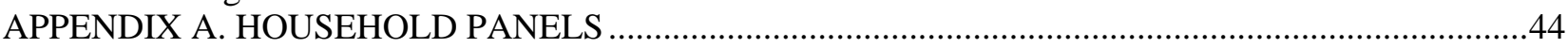

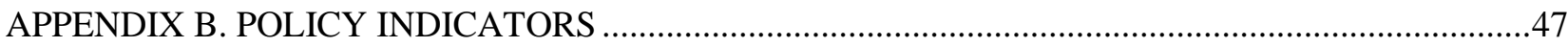

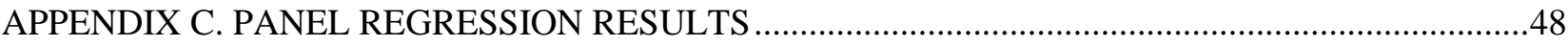

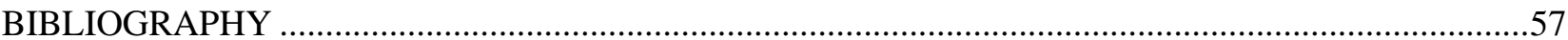

\section{Tables}

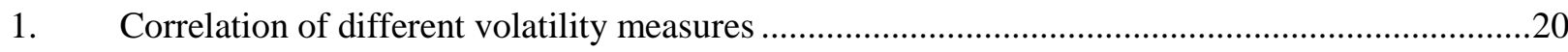

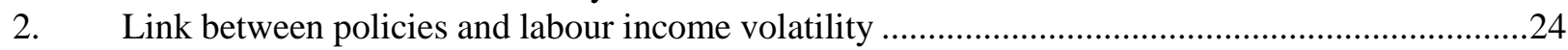

3. Distance to growth-volatility frontier and structural policies .................................................41

4. Equality and stability trade-offs of pro-growth reforms ..........................................................42

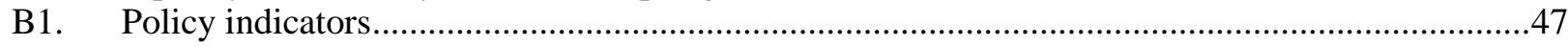

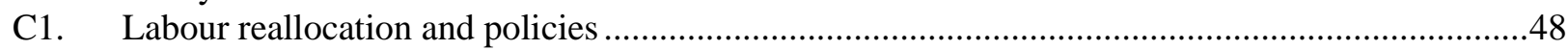

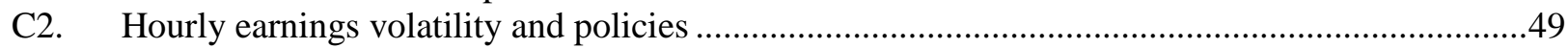

C3. Annual hours worked, policies and individual characteristics ..................................................50

C4. Volatility of hourly earnings, policies and individual characteristics ........................................52

C5. Country coverage in the macro and micro level regressions ..................................................54

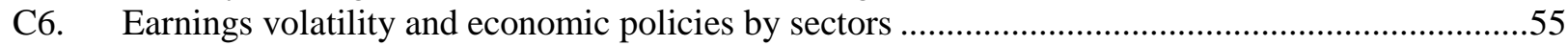

C7. Distance to growth-volatility frontier and structural policies .......................................................56

\section{Figures}

1. Macroeconomic volatility is much lower than microeconomic volatility....................................... 8

2. Household-level disposable income volatility before and during the Great Recession ...................9

3. Changes in volatility and unemployment showed no systematic link during the Great Recession 
$4 \quad$ Microeconomic volatility and income inequality are positively related ....................................11

5. Life satisfaction and micro-level volatility are negatively correlated.........................................11

6. Regulatory settings differ between countries with high and low firm turnover.............................14

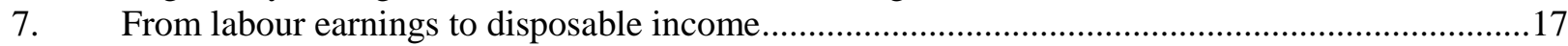

8. Annual worker reallocation rates vary considerably across countries .........................................18

9. Many separation and hiring decisions involve job-to-jobless or jobless-to-job transitions ............19

10. The link between earnings and income variables .................................................................19

11. Cross country differences in annual hours worked and hourly earnings volatility .......................21

12. Relationship between worker reallocation and earnings volatility ..........................................22

13. Hourly earnings volatility decreased after Estonia implemented a major reform of EPL .............25

14. Impact of structural policies on labour income volatility by age group.....................................27

15. Impact of structural policies on labour income volatility by level of education ...........................28

16. Impact of structural policies on labour income volatility by level of income...............................29

17. Earnings volatility and the EPL in binding and non-binding industries ...................................31

18. Earnings volatility and PMR in binding and non-binding industries............................................

19. Capital income volatility is higher than labour and disposable income volatility ........................32

20. Capital income is less volatile in countries with more progressive taxation..................................33

21. Contributions to changes in household disposable income ........................................................35

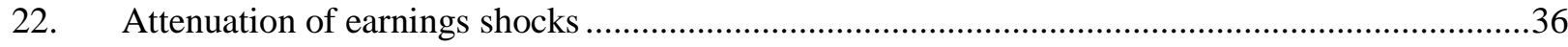

23. Tax-and-benefit systems differ between high and low attenuation countries ...............................37

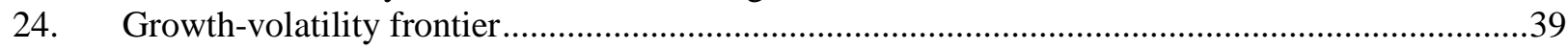

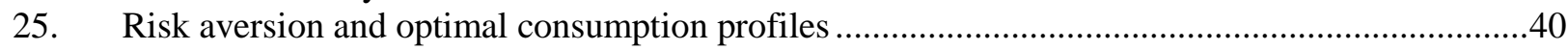

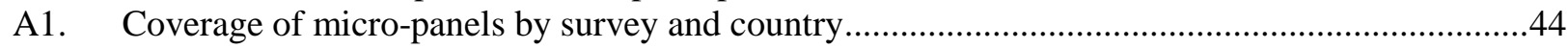

A2. Number of observations by suvrey length per household .....................................................45

A3. Distribution of household disposable income growth...............................................................

A4. Household disposable income volatility excluding very large changes is highly correlated with

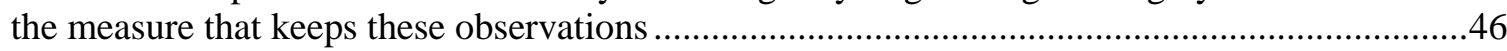

\section{Boxes}

Box 1. Microeconomic volatility during the Great Recession ...............................................................

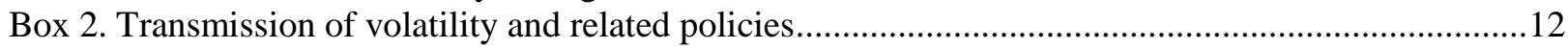

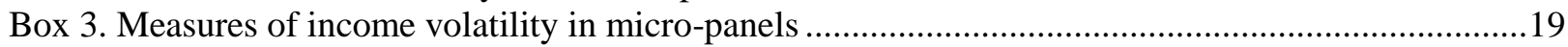

Box 4. Using industry data to investigate the effect of policies across countries .....................................30

Box 5. Household welfare and the efficient consumption frontier .......................................................39 


\title{
EFFECTS OF ECONOMIC POLICIES ON MICROECONOMIC STABILITY
}

\author{
By Boris Cournède, Paula Garda and Volker Ziemann ${ }^{1}$
}

\section{Introduction and conclusions}

1. In the wake of the recent crisis, side-effects of growth-enhancing policies on other dimensions of well-being have been at the forefront of OECD analysis. An important dimension is the effect of growthenhancing policies on economic stability, which recent studies for the Working Party have assessed at the macroeconomic level (Sutherland et al., 2012; Ziemann, 2013; Sutherland and Hoeller, 2013). From a welfare perspective, instability at the level of individual workers or households is even more relevant. The present paper investigates how it relates to macro-level volatility and growth and how it is influenced by economic policies and labour-market institutions.

2. The main findings are:

- Household-level disposable income shows much higher economic instability than at the aggregate level. Surprisingly, micro-level instability is not correlated with macroeconomic instability across countries. Household-level economic instability did not increase more in countries that were more severely hit by the Great Recession, at least in the first years of the crisis.

- Household-level economic instability tends to be greater in more unequal countries, partly because policies such as the tax and benefit system help reduce both inequality and volatility.

- Firm-level instability can reflect reallocation processes, which underpin economic growth. Firmlevel instability is in general greater in countries with lower levels of employment protection, better contract enforcement and lower public ownership.

- Worker-level economic volatility can take the form of changes in jobs (including into or out of employment), working-time or hourly earnings. All three forms of economic instability are high and vary considerably across countries. Worker-level volatility is not always bad; it can also reflect a more dynamic labour market with more job opportunities and social mobility. However, not all workers benefit from more dynamic labour markets, and especially displaced workers during recessions tend to suffer from long term earnings losses.

- Empirical investigations yield the following results:

1. The authors are members of the OECD Economics Department. The Working Party No. 1 of the OECD Economic Policy Committee discussed the material presented in this paper. The authors are grateful to Peter Hoeller, Christian Kastrop, Jean-Luc Schneider and Working Party No. 1 participants for their guidance. They would like to thank Alexandre Cazeneuve-Lacroutz, Lorenzo Codogno, Oliver Denk, Mathilde Mesnard, Paul O'Brien, Karin Rysavy and Stefano Scarpetta for their comments. Special thanks go to Jenifer Ruiz Valenzuela for her important econometric contributions to the industry-level analysis, Pascal Marianna for his help on micro-level databases and Celia Rutkoski for excellent editorial assistance. 
- Relaxing employment protection legislation for regular workers (EPL) increases worker-level economic instability, when it results in a moderate level of protection. However, reforms leading to very competitive settings can be expected to reduce instability.

- Easing product-market regulation (PMR) shows similar effects: economic instability typically increases when reform results in moderately tight settings. By contrast, moving to very competitive settings generally reduces instability.

- Countries with moderately tight EPL and PMR can expect that deregulation will boost both growth and stability.

- Centralised and decentralised wage-bargaining systems bring greater worker-level stability in hours worked and hourly earnings than intermediate, sector-level arrangements.

- Higher levels of unemployment benefits are associated with greater labour income volatility in hours worked and hourly earnings. This link may reflect that stronger unemployment insurance facilitates risk taking in the labour market.

- More spending on active labour market policies reduces gross worker flows, presumably by improving the matching process in hiring.

- Large changes in individual labour earnings are strongly attenuated at the household level.

- Taxes are key levers in dampening the transmission of large changes in labour earnings to household disposable income.

- Social transfers also reduce the transmission of shocks from labour earnings to disposable household income, but to a lesser extent.

- The "protection mechanisms" against large declines in labour earnings vary considerably across countries.

- Taxes and transfers are as important shock absorbers as income of other family members in the Nordic countries.

- Earnings from other family members are the most important smoothing source in southern European countries.

- Growth-enhancing reforms appear to bring countries closer to the maximum level of growth that has been observed across countries for a given level of instability. In other words, growthenhancing reforms can ensure that microeconomic instability is not "wasted" and instead used to generate growth. This effect has been tentatively identified for expanding active labour market programmes, reducing employment protection for regular workers and lowering unemployment insurance replacement rates. A novel, still exploratory methodological approach underpins this result, which should therefore be regarded as tentative. 
3. The remainder of this paper is organised as follows. Section 2 discusses the links between microeconomic volatility, growth and welfare, while Section 3 proposes a framework to identify different channels through which economic policies can influence volatility. Section 4 presents the data and measures of microeconomic volatility used throughout the study. Section 5 investigates the links between different indicators of microeconomic volatility and economic policies. Finally, Section 6 sheds some light on the trade-off between growth and volatility and how it is affected by economic policies.

\section{Why is microeconomic volatility important?}

4. Microeconomic volatility, that is fluctuations in the economic situation of households, matters directly for economic welfare. Partly unpredictable changes in economic conditions around a given level create uncertainty, which reduces welfare because the vast majority of people are averse to risk. From a conceptual point of view, the reason why volatile consumption reduces individual welfare is the same as the reason why an uneven distribution of resources across individuals reduces aggregate welfare. For instance, simply assuming that an individual gets less and less satisfaction from each additional unit of consumption means that aggregate welfare is greater when resources are more evenly shared across people and when they are more stable over time. In other words, logic compels a society that cares about inequality to care about microeconomic volatility as well. Microeconomic volatility influences individual welfare through its effect on households because economic resources are shared within households.

5. Instability of their income after taxes and transfers (thereafter disposable income) is a key indicator of households' economic instability, which is used throughout this study. From a welfare perspective, instability in household consumption would be even more directly informative; however, sufficient micro-level data over time and across countries are not available. This is one area where advances in the collection of statistics would be clearly welcome.

6. The correlation patterns across individual earnings and consumption profiles drives a wedge between macroeconomic and microeconomic volatility, which further undermines the validity of macroeconomic volatility as an indicator for welfare-related economic stability. In fact, real disposable income volatility at the macroeconomic level is always much lower than average real disposable income volatility at the household level (Figure 1).

Figure 1. Macroeconomic volatility is much lower than microeconomic volatility

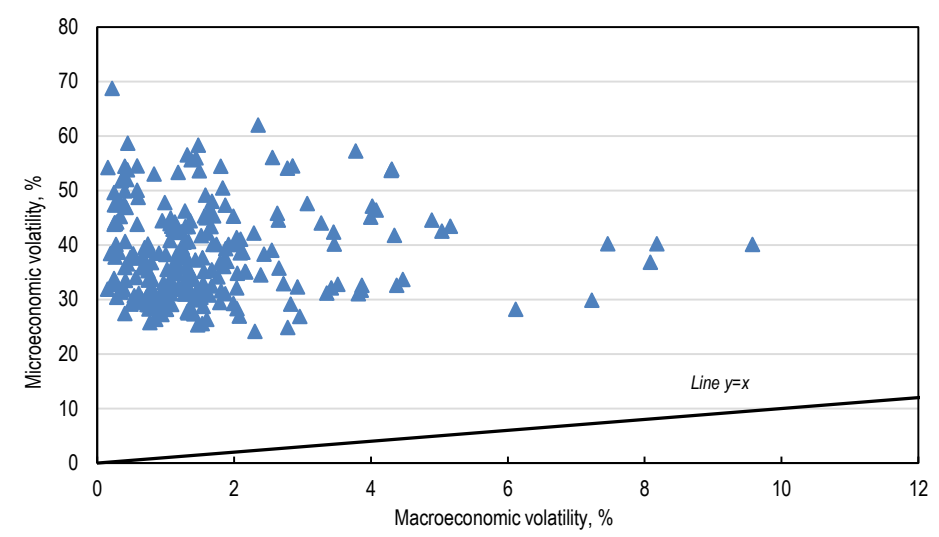

Note: Each observation represents a country at a specific year for the period 1994-2010. Microeconomic volatility is measured by the cross-sectional standard deviation of disposable income growth across households in a given country. See Box 2 in Section 4.1 for a presentation of micro-level volatility measures. Macroeconomic volatility is calculated as the 3-year rolling window standard deviation of real disposable income growth measured in the national accounts.

Source: CNEF, SILC and ECHP for household income at the individual level and OECD National Accounts for aggregate disposable income. 
7. The volatility of household-level disposable income growth takes large values because many households experience large changes. In a typical year over the 1994-2010 period, one third of households living in OECD countries saw their disposable change by more than one third. This strong income variability at the micro level reflects the multiplicity of events that can generate large changes in earnings such as when one household member becomes unemployed, takes up a job, goes on unpaid parental leave, restarts work afterwards, goes part-time, retrains or stops working temporarily when the household moves to a different location.

8. Furthermore, microeconomic volatility is not correlated with macroeconomic volatility (Figure 1). Macroeconomic volatility is only one of many factors that can drive microeconomic volatility (Section 3). Indeed, changes in microeconomic volatility during the Great Recession show no systematic link with the depth of the downturn (Box 1).

9. This finding suggests the presence of complicated sub-channels in the transmission from macro to micro-level volatility. For instance, it could be that low macro-level volatility makes households and firms more confident to take micro-level risks, while high macro-level volatility could generate uncertainty and anxieties so that firms and households stick to the status quo as much as possible. These opposite effects might be offsetting one another.

\section{Box 1. Microeconomic volatility during the Great Recession}

Changes in microeconomic volatility during the Great Recession have been relatively small, despite the severity of the downturn. Even more so, micro-level volatility decreased in 15 out of the 22 countries for which data are available (Figure 2). ${ }^{0}$ However, countries that experienced sharp increases in unemployment, such as Spain and the United Kingdom, also witnessed large rises in microeconomic volatility. Despite these examples, there is no systematic link between labour-market performance during the crisis and changes in microeconomic volatility (Figure 3).

Figure 2. Household-level disposable income volatility did not rise everywhere during the Great Recession

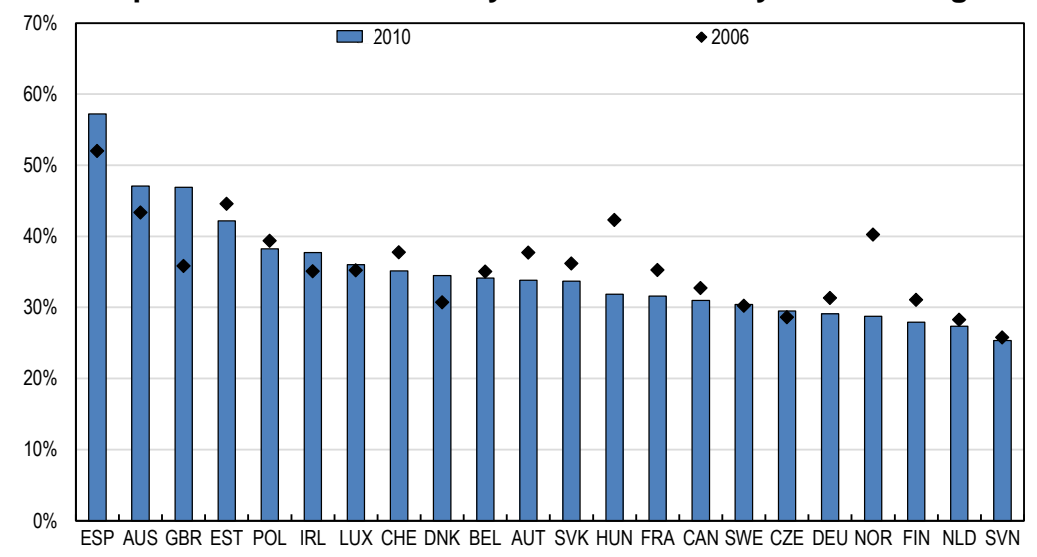

Note: Microeconomic volatility is the cross-sectional standard deviation of disposable income growth across households at the country level. Figures for the years 2006 and 2010 if available. The end date is 2009 for SWE and SVK, and 2008 for AUS, CHE, DEU and IRL.

Source: CNEF; SILC; ECHP; OECD calculations. 
Box 1. Microeconomic volatility during the Great Recession (cont.)

An important caveat is that the data for the Great Recession refer to 2010. However, the crisis deepened in the following years in some OECD countries, especially in southern Europe. There is a possibility that changes in microeconomic volatility may have become more tightly linked with labour market performance in the years that followed 2010, an issue which cannot be investigated until data covering the whole crisis period become available.

Figure 3. Changes in volatility and unemployment showed no systematic link during the Great Recession 2006-10 change, percentage points

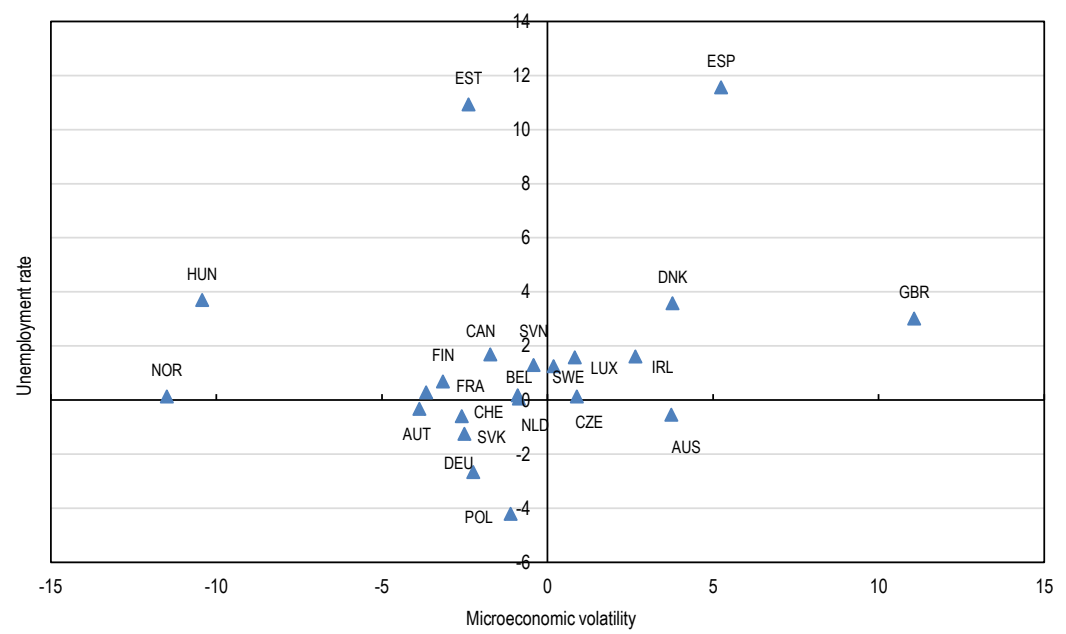

Note: Each point represents changes in the unemployment rate and micro-level volatility between 2010 and 2006. Microeconomic volatility is measured as the cross-sectional standard deviation of disposable income growth across households at the country level.

Source: CNEF; SILC; ECHP; OECD database.

1. Negative volatility (defined as the proportion of households having large disposable income declines) was more frequent in 2010 than 2006 in only half of the countries covered.

10. Income inequality across people and volatility for each person both reduce household welfare. The reason is that the additional utility from one extra unit of income decreases with the level of income. Countries that tend to have high income inequality also experience strong microeconomic income volatility (Figure 4). This link may partly be due to policies such as taxes and transfers, which reduce both inequality and volatility. Furthermore, more compressed earnings distributions reduce the extent to which income can rise or fall in the face of individual shocks or opportunities. 
ECO/WKP(2015)19

Figure 4. Microeconomic volatility and income inequality are positively related

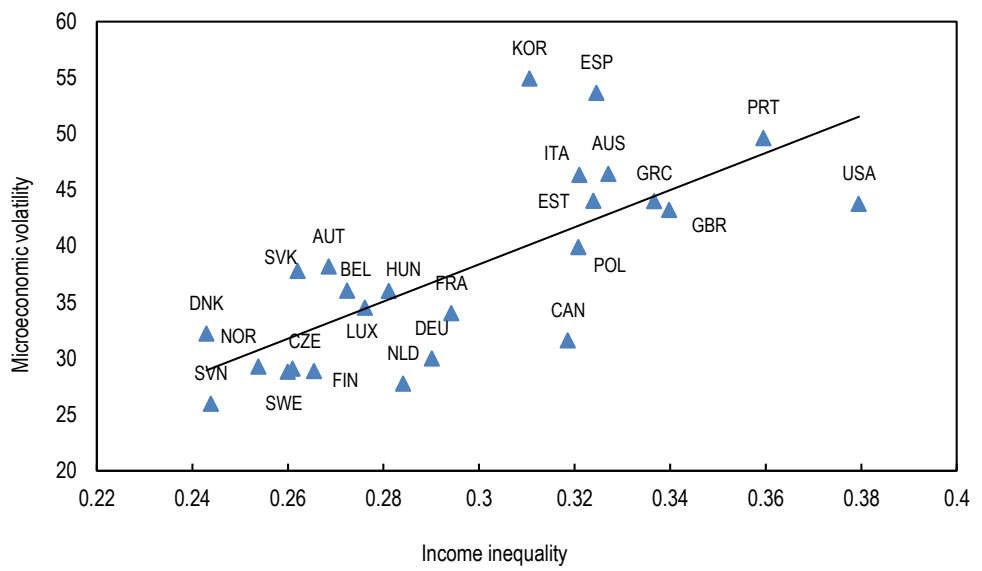

Notes: Microeconomic volatility (in \%) is the cross-sectional standard deviation of disposable income growth across households in each country. Figures represent averages for the period 2005 10. See Box 2 in Section 4.1 for a presentation of volatility measures and Section A.2 in Appendix A, for further details and a discussion of the distribution of income changes. Income inequality is measured by the Gini index of household disposable income. The Gini coefficient ranges from 0 (perfect equality) to 1 (one individual receives all of the income and the others none).

Source: CNEF, SILC and OECD Income distribution dataset.

11. Data about well-being indicate that household-level volatility matters in practice. The OECD gathers survey-based indicators of well-being (OECD, 2013a). Figure 5 suggests that disposable income volatility at the household level is indeed negatively correlated with self-reported life satisfaction (right panel) while macroeconomic volatility of disposable income growth is not (left panel).

Figure 5. Life satisfaction and micro-level volatility are negatively correlated
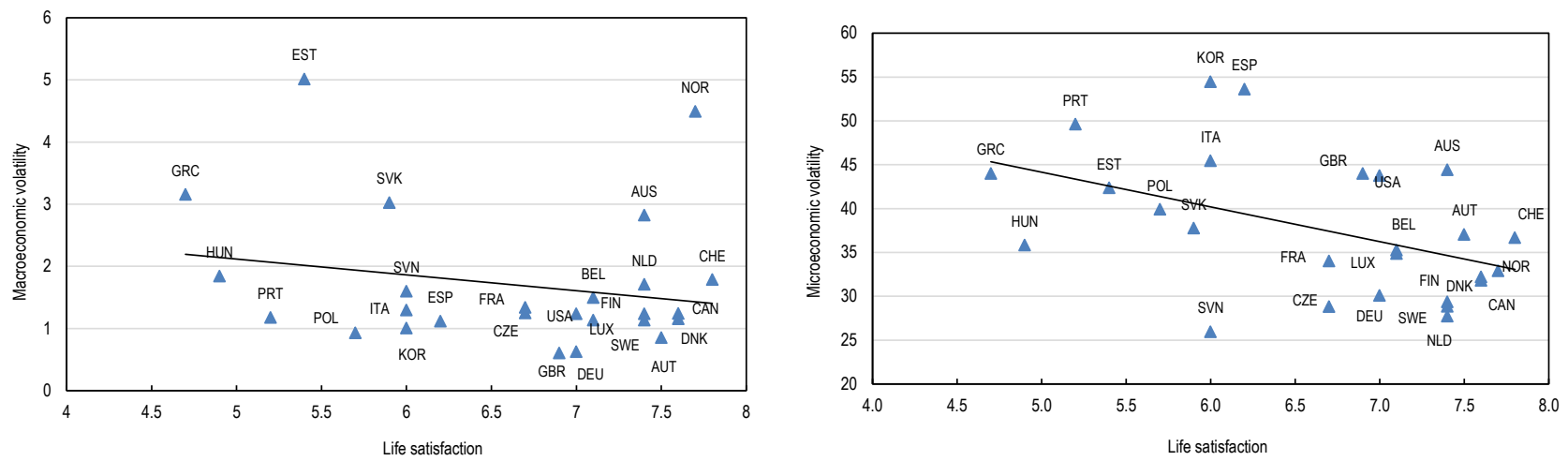

Note: Microeconomic volatility is measured by the average of the cross-sectional standard deviation of disposable income growth across households at the country level between 2005 and 2010. See Box 2 in Section 4.1 for a detailed description of volatility measures. Macroeconomic volatility refers to the 3-year rolling window of the standard deviation of real disposable income growth as measured by the national accounts at the aggregate level.

Source: OECD Better Life Index. OECD National Accounts. Household income data from CNEF and SILC.

\section{What role do economic policies play?}

12. This section proposes a simple framework to assess how economic policies and labour market institutions shape the relationship between growth and volatility at the micro level. This framework does so by following the channels through which changes in economic conditions affect consumption growth and volatility (Box 2). 


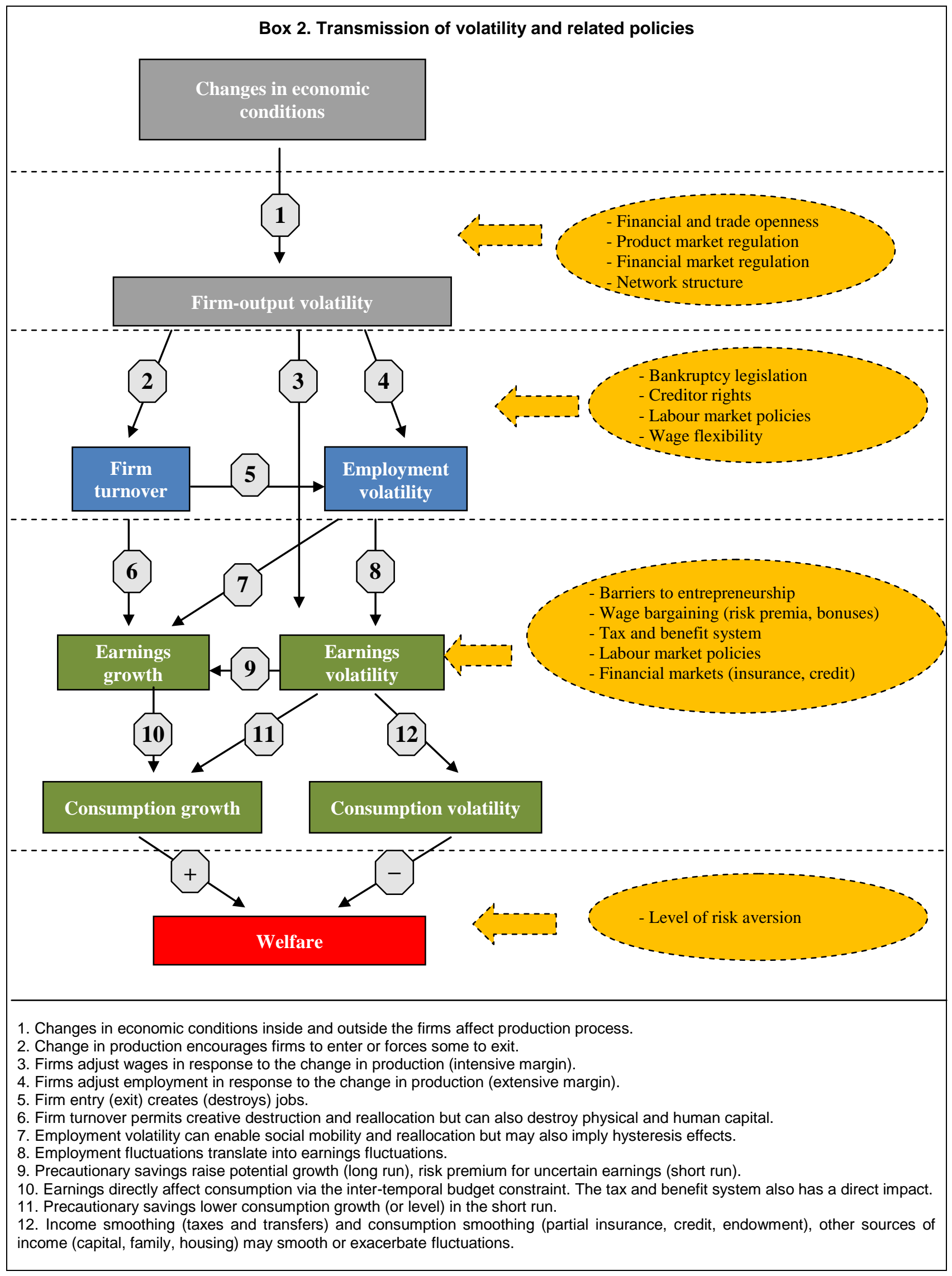


13. The framework only lays out the marginal impacts of output volatility on earnings, consumption and welfare and takes all other determinants as exogenous. This simplicity comes at the cost of potential biases. Individual welfare, for instance, is also driven by leisure, health and environmental factors that may themselves be affected by the investigated economic policies and institutions. These effects lie outside the scope of the present analysis.

\section{The likelihood and extent of changes in economic conditions}

14. Changes in economic conditions are not necessarily related to macroeconomic shocks; they can occur at the level of households, firms, sectors, countries or the global economy. Institutional features and policies can shape the likelihood of experiencing exogenous or endogenous changes.

15. At the country level, financial development and the size of the financial sector may come at the cost of greater vulnerability. Indeed, financial deregulation induces greater risk-taking in the financial sector which often creates negative externalities on other sectors trough more volatile credit growth and a higher probability of financial turmoil and credit crunches (Korinek and Kreamer, 2013; Sutherland et al., 2012). Similarly, Brunnermeier and Sannikov (2014) show that a large and innovative financial sector can lead to the paradoxical situation where instruments meant to better manage risks and diversify idiosyncratic risk may actually increase systemic risks and instability.

16. At the firm level, product market deregulation and other innovation-enhancing policies such as R\&D subsidies are likely to prompt productivity changes (Comin and Mulani, 2009; Aghion and Griffith, 2008). Trade openness exposes firms to external sources of risk (Vannoorenberghe, 2012).

17. The extent to which a change in economic conditions raises firm-level output volatility depends, inter alia, on its nature (demand vs. supply, transitory vs. permanent, positive vs. negative, macro vs. micro), its size and characteristics of the firm. For instance, demand shocks are likely to modify output, while cost-push shocks, depending on the wage and price elasticity of demand, may partly be absorbed by adjustments in wages and prices. The size and duration of the change in economic conditions also matter. Small transitory demand changes may be smoothed by inventory changes. Better inventory management has indeed been identified as one of the main microeconomic drivers of the decline in aggregate output volatility prior to the Great Recession (Davis and Kahn, 2008). Moreover, greater financial development in principle helps individual firms to smooth transitory shocks, although aggregate financial over-extension can generate macro-level instability (Sutherland et al., 2012).

18. The transmission of volatility throughout the economy also depends on the structure of firm and customer networks (Acemoglu et al., 2012). Carvalho and Gabaix (2013) show how output changes at large interconnected firms can propagate through the network and affect other firms and thus volatility. On the other hand, Kelly et al. (2013) illustrate that big firms with a well-diversified network of customers are less affected by idiosyncratic demand changes. Trade openness, by increasing export exposure, permits greater international diversification (Buch et al., 2009).

\section{Firm turnover}

19. Once a change in economic conditions affects firm production processes, several adjustments can occur. The change can prompt some firms to exit the market while encouraging others to enter it. GarcíaVega et al. (2012) show that more volatile firms are more likely to go bankrupt. While high firm turnover can be interpreted as a sign of instability, it may also reflect adaptability in reallocating resources from non-viable to high-growth firms, known as creative destruction. Endogenous growth models pioneered by Aghion and Howitt (1992) illustrate how creative destruction can raise an economy's growth potential. 
20. Policies and institutions can accompany firms and help them to cope with volatility and uncertainty. Figure 6 indicates that regulatory constraints seem to influence firm entry and exit rates (hereafter referred to as firm turnover rates). Greater public ownership is associated with lower firm turnover rates. Finally, barriers to competition and barriers to trade and investment are also associated with lower firm turnover as they protect incumbent firms and also lead to lower risk taking.

21. Stringent employment protection lowers firm turnover and is negatively associated with the size of high-risk innovative sectors, as high firing costs reduce the expected value of risky innovations and induce firms to stick with less productive but better known technologies (Bartelsman et al., 2013). In addition, the related high exit costs lower the productivity threshold below which firms exit the market, which not only increase the dispersion of productivity across firms but also lowers average productivity. Similarly, Poschke (2009) shows that too stringent employment protection impedes labour reallocation, discourages entry of firms but also delays exit of unproductive firms and thereby lowers growth.

22. Finally, high barriers to firm entry and stringent bankruptcy legislation reduce the market share of more productive firms in an industry, ${ }^{2}$ especially in high turnover sectors (Andrews and Cingano, 2012). In addition, anti-competitive regulation and low financial development are negatively associated with average productivity.

\section{Figure 6. Regulatory settings differ between countries with high and low firm turnover}

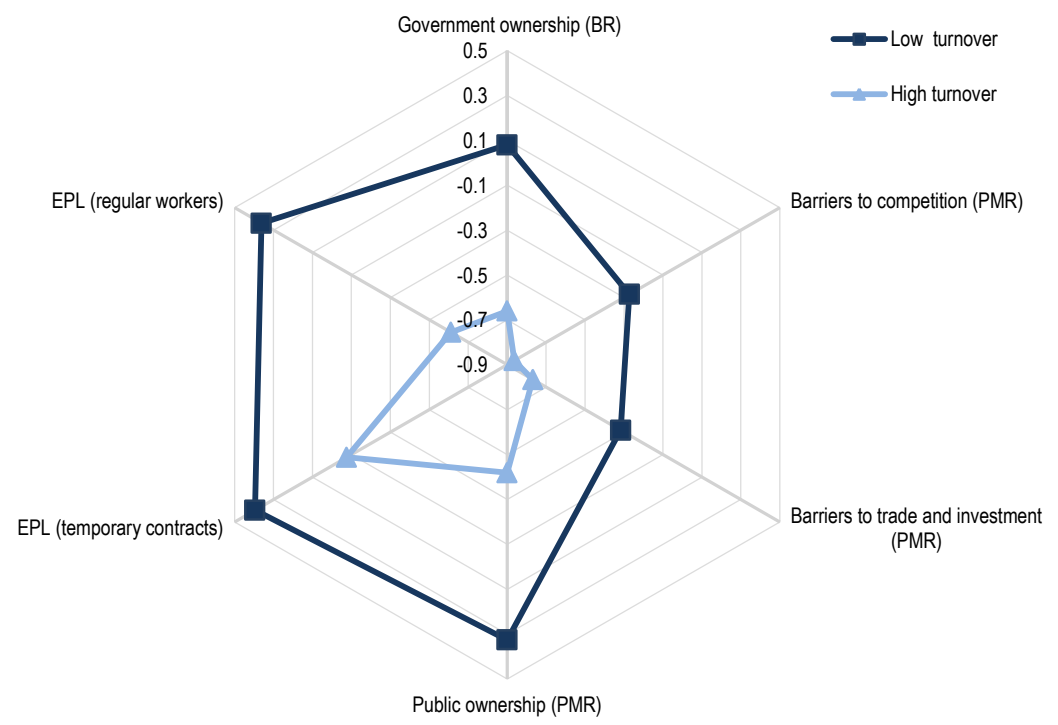

Note: Countries have been separated in two groups depending on their turnover rate. Low turnover rate countries are DEU, DNK, FRA, LUX, NOR and SVN and high turnover rate countries are FIN, GBR, IRL, ITA and NLD. The indicators are standardised to have OECD-wide zero mean and a standard deviation of one. Zero indicates the average across the OECD area, which can differ from the average across the 11 covered countries for which data about firm turnover is available. BR stands for Banking Regulation index (de Serres et al., 2006). EPL is employment protection legislation and PMR means product market regulation (OECD database).

Source: Gross firm turnover rates for 11 European countries between 2003 and 2007 from Bartelsman et al. (2013), "Employment Protection, Technology Choice, and Worker Allocation", The Quarterly Journal of Economics, Vol. 128, No. 1, pp. 249-85.; De Serres et al. (2006), "Regulation of Financial Systems and Economic Growth in OECD Countries: An Empirical Analysis", OECD Economic Studies, Vol. 43, pp. 77-113, OECD Publishing.

2. This is called allocative efficiency, measured by "the extent to which the more productive firms in an industry have higher market share". It is defined as the difference between market share-weighted productivity and average productivity within a sector. 
ECO/WKP(2015)19

\section{Employment volatility}

23. Output volatility can also affect labour compensation or employment. Employment volatility can involve changes in hours worked or hiring or firing. Economic policies ranging from bankruptcy law to employment protection and wage setting do not only shape the volatility of firm output and turnover, but also worker reallocation or changes in hours or wages.

24. Higher labour reallocation tends to be associated with higher employment volatility. While reallocation can reflect separations that lead to unemployment, a more dynamic labour market may also provide better access to jobs (Petrongolo and Pissarides, 2008). However, not all workers benefit from the dynamism of the labour market in the same way. Displaced workers are likely to experience difficulties to find a job and experience long-lasting wage losses, in particular those dismissed during recessions (von Wachter and Davis, 2011).

25. There is a lot of heterogeneity in job and worker flows across OECD countries. This suggests that country-specific policies and institutions may play an important role in determining the level of job and worker reallocation (OECD, 2010).

26. High firm turnover goes hand in hand with high job turnover (Bartelsman et al., 2013). In addition, surviving young firms typically exhibit high rates of employment growth. This link suggests that barriers to entrepreneurship and, more generally, barriers to product market competition influence labour reallocation.

27. More stringent employment protection legislation (EPL) could decrease labour reallocation by decreasing firm's incentives of job creation and job destruction. However, if temporary contracts are less costly than open-ended contracts, employers will substitute temporary for regular workers, with the effect of increasing worker turnover. However, empirical studies provide mixed results on how EPL affects worker reallocation and employment volatility. Bassanini and Garnero (2013), using industry level data, suggest that more restrictive dismissal regulations reduce the rate of job-to-job transitions within industries, while they have no effect on transitions towards unemployment or transitions across industries.

28. Public spending on active and passive labour market policies also affects persistence after adverse shocks to employment. Unemployment benefits increase the reservation wage, which can weaken job-search intensity. The disincentive effect of job-search could be partially offset by active labour market policies (ALMPs), which are expected to increase the probability of re-employment of workers by training workers during unemployment and improving the matching process.

29. The wage bargaining process also affects labour reallocation. Previous research suggests that structural unemployment is generally lower in countries with either highly coordinated/centralised wage bargaining or uncoordinated/decentralised wage-setting institutions compared with intermediate bargaining arrangements. Generally, in countries with highly centralised or coordinated wage setting, it is possible to internalise the detrimental employment effects of excessive wage pressures which may allow the economy to adjust more quickly to shocks (Bassanini and Duval, 2006). However, if shocks are heterogeneous across the economy and persistent, adjustment may become more difficult relative to a fully decentralised system. 


\section{Labour earnings fluctuations}

30. Besides firm entry or exit, firms may also adjust the wage bill, by hiring or firing workers, adjusting hours worked or hourly wages to cope with a change in the economic conditions. For the United States, Comin et al. (2009) find that the volatility of firm sales growth and the volatility of incumbent workers' wage growth are significantly and positively correlated and that the strength of this association has been growing since the 1980s.

31. Firms can adjust the hourly wage paid to their employees or their working time. While there is wide agreement on the existence of downward nominal wage rigidity (Nickell and Quintini, 2003; Holden, 2004), empirical evidence shows that a fair number of job stayers experience wage reductions during recessions. Elsby et al. (2013) find that the share of workers that undergo nominal wages declines generally lies between $10 \%$ and $20 \%$ in the United States and the United Kingdom and culminated at around 25\% during the Great Recession. Nevertheless, nominal wage declines remain limited in many other countries thus impeding real wage adjustment in times of low inflation and leading to higher structural unemployment and lower growth (Fehr and Goette, 2005).

32. On the other hand, part-time jobs and flexible working hour schemes have gained traction in recent years, potentially amplifying fluctuations in hours worked while stabilising employment. At the macroeconomic level, Ohanian and Raffo (2011) show that volatility in hours per worker contribute considerably to labour input fluctuations in the main euro area countries and Japan, while volatility of labour input is largely determined by employment fluctuations in English-speaking countries. This is consistent with the view that different labour market institutions, notably differences in hiring and firing costs and work-sharing arrangements, may significantly affect how firms adjust labour input along the extensive and intensive margin.

\section{Implications for consumption}

33. Earnings growth is positively linked with consumption growth via the budget constraint, although other income sources such as capital income, social transfers or family member earnings may weaken the link. Therefore, changes that both raise volatility and underpin potential growth (for instance, via social mobility, career opportunities and Schumpeterian creative destruction) contribute positively to consumption growth. On the other hand, volatility induces precautionary savings which leads to lower consumption.

34. The transmission of earnings volatility to consumption volatility is not straightforward. Its strength depends on the ability of households to smooth consumption and on the tax and benefit system, which partly shields disposable income from labour income volatility.

35. Consumption growth and volatility are most relevant to welfare. However, in the absence of harmonised cross-county data for individual household consumption, the present study focuses on personal earnings or household disposable income.

36. Another assumption implicit in the study is that, for a given level of consumption, greater volatility is undesirable. This assumption is highly plausible when households suffer volatility involuntarily. However, volatility in household consumption may not hurt their welfare when it results from voluntary choices, such as changes in lifestyle. Lack of data did not permit quantifying the role of voluntary choices in observed microeconomic volatility.

37. Figure 7 illustrates how different institutional settings and economic policies are likely to affect the transmission of labour earnings volatility to household disposable income. Fluctuations in labour income, which involve changes in hours, employment status or hourly earnings affect household 
disposable income after a number of steps involving household structure, capital income, taxes and transfers. This paper looks at the impact of policies on employment and labour earnings volatility and studies how labour earnings volatility fuels disposable income volatility while investigating the role of taxes and transfers. This sequential approach allows identifying the main policy drivers of volatility at each income level as well as their build-up along the chain.

Figure 7. From labour earnings to disposable income

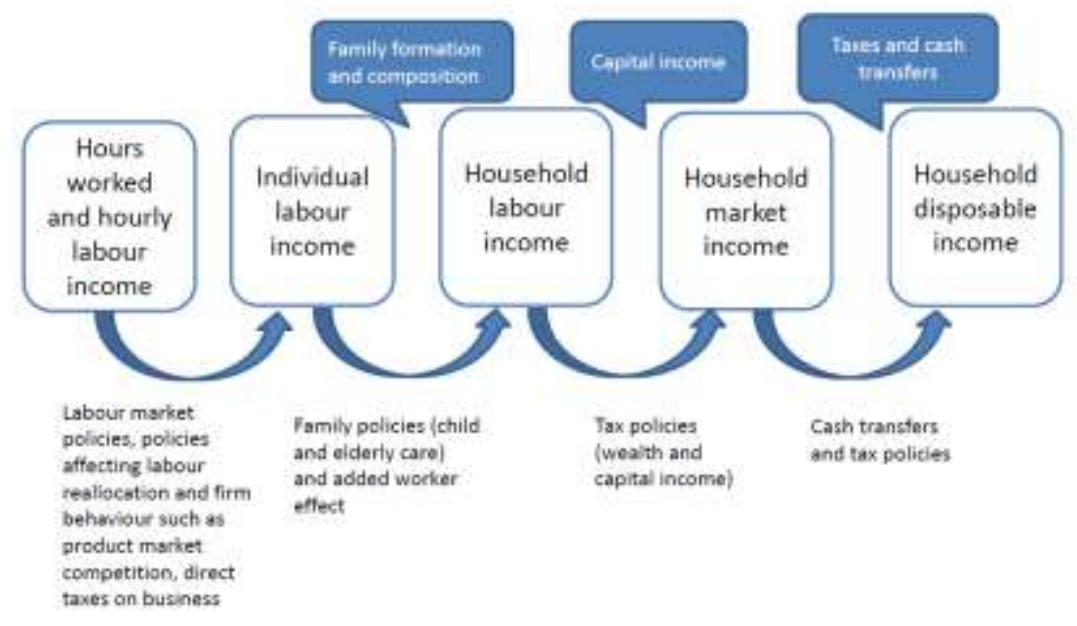

\section{Data and measures}

38. This section presents the data, reviews various volatility measures and introduces the econometric specifications. The framework presented in Section 2 suggests focussing the analysis on i) job reallocation, ii) individual earnings volatility and iii) disposable income volatility. Two main types of data sources are used: labour force surveys and household panels.

\subsection{Labour force surveys}

39. Worker reallocation comprises two distinct types of labour reallocation: churning, that is, worker flows without creation or destruction of jobs; and job reallocation defined as creation and destruction of jobs. Both types are likely to influence productivity by stimulating the accumulation of human capital or reflecting flexibility at the firm level to accommodate innovation and creative destruction. On the other hand, job flexibility and employment volatility entail uncertainty and increased instability for individual workers. A dynamic labour market provides workers with better job opportunities. However, not all workers benefit. Dismissed workers can have problems to find a job and if they find one, they may not have the same level of income and working conditions as in the previous job. The trade-off between these two dimensions of welfare will be addressed in Section 6.

40. The present paper uses Labour Force Survey (LFS) data to measure the intensity of worker flows as a measure for worker reallocation. Hiring rates are defined as the proportion of workers with tenure of less than one year, while separations are simply the difference between hirings and employment changes for a given year. These rates are available for 26 countries and cover horizons between 1993 and 2010 . Akin to Bassanini et al. (2010), worker reallocation is defined as worker hiring (H) and separation (S) rates in excess of net employment growth (E):

$$
x=0.5 *(H+S-|\Delta E|)
$$


41. Figure 8 shows that worker reallocation rates are very different across OECD countries. The English-speaking and Nordic countries have reallocation rates well above those observed in other European countries with the exception of Spain. With the exception of Spain, reallocation rates have generally increased between 1995 and 2007 for countries where data is available in both years.

Figure 8. Annual worker reallocation rates vary considerably across countries

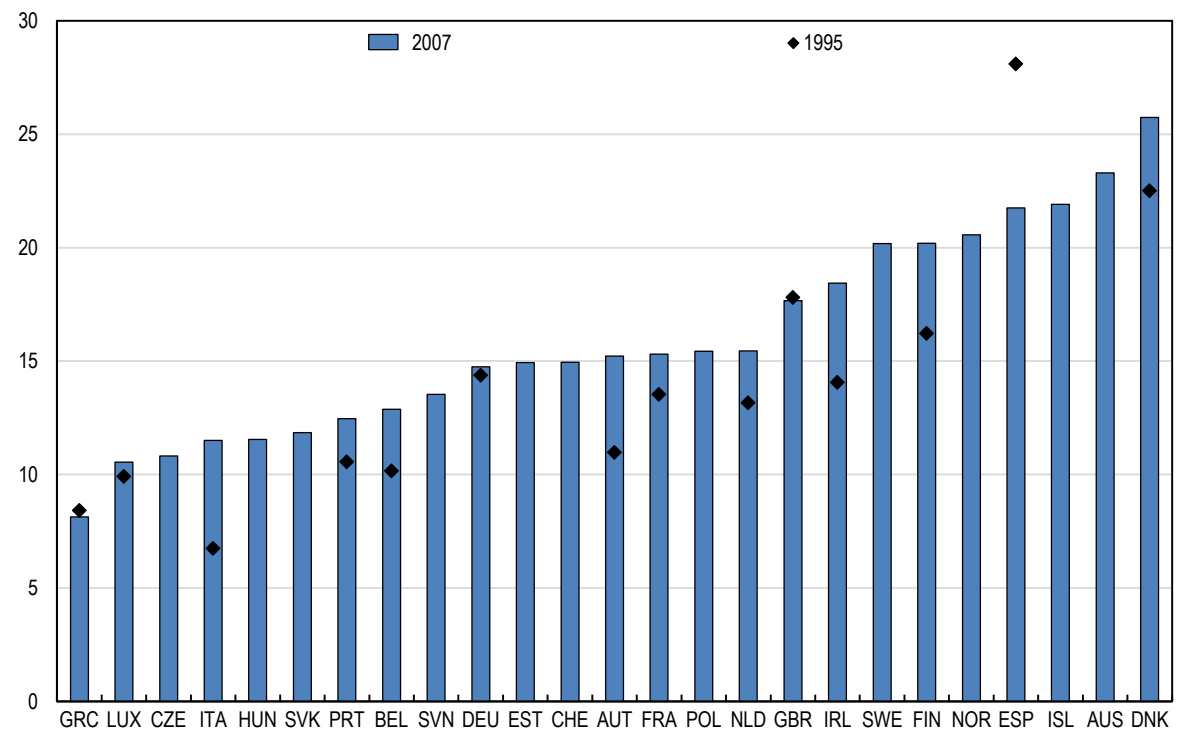

Note: Worker reallocation is defined as hirings plus separations minus the absolute value of employment growth divided by two.

Source: OECD Labour Force Surveys and OECD calculations.

42. Figure 9 shows the decomposition of worker reallocation into separation and hiring rates. ${ }^{3}$ Separation and hiring rates are due to job-to-job transitions or transitions from or into unemployment. About $45 \%$ of all hires in one year concerns workers that were not in employment at the beginning of the year, that is to say jobless-to-job hires. Moreover, the cross-country variation in hiring rates is strongly associated with that of the jobless-to-job transition rate, which measures the pace at which non-employed individuals get into employment. As a result, more worker reallocation is associated with a lower percentage of the labour force in unemployment for more than one year.

43. Finally, job-to-jobless separations tend to be more frequent in countries with larger average separation rates. Some of these separations are voluntary quits, but almost $40 \%$ of all separations are involuntary (dismissals, plant closures or ends of contract). The evidence suggests that higher rates of reallocation go together with larger shares of employees who separate involuntarily from their employer in a given year, often with negative consequences for their careers, such as large wage losses and worse working conditions upon re-employment (OECD, 2010).

3. These data will not be used in regression analysis since they are not available on a yearly frequency and only for a short period of time. 
Figure 9. Many separation and hiring decisions involve job-to-jobless or jobless-to-job transitions
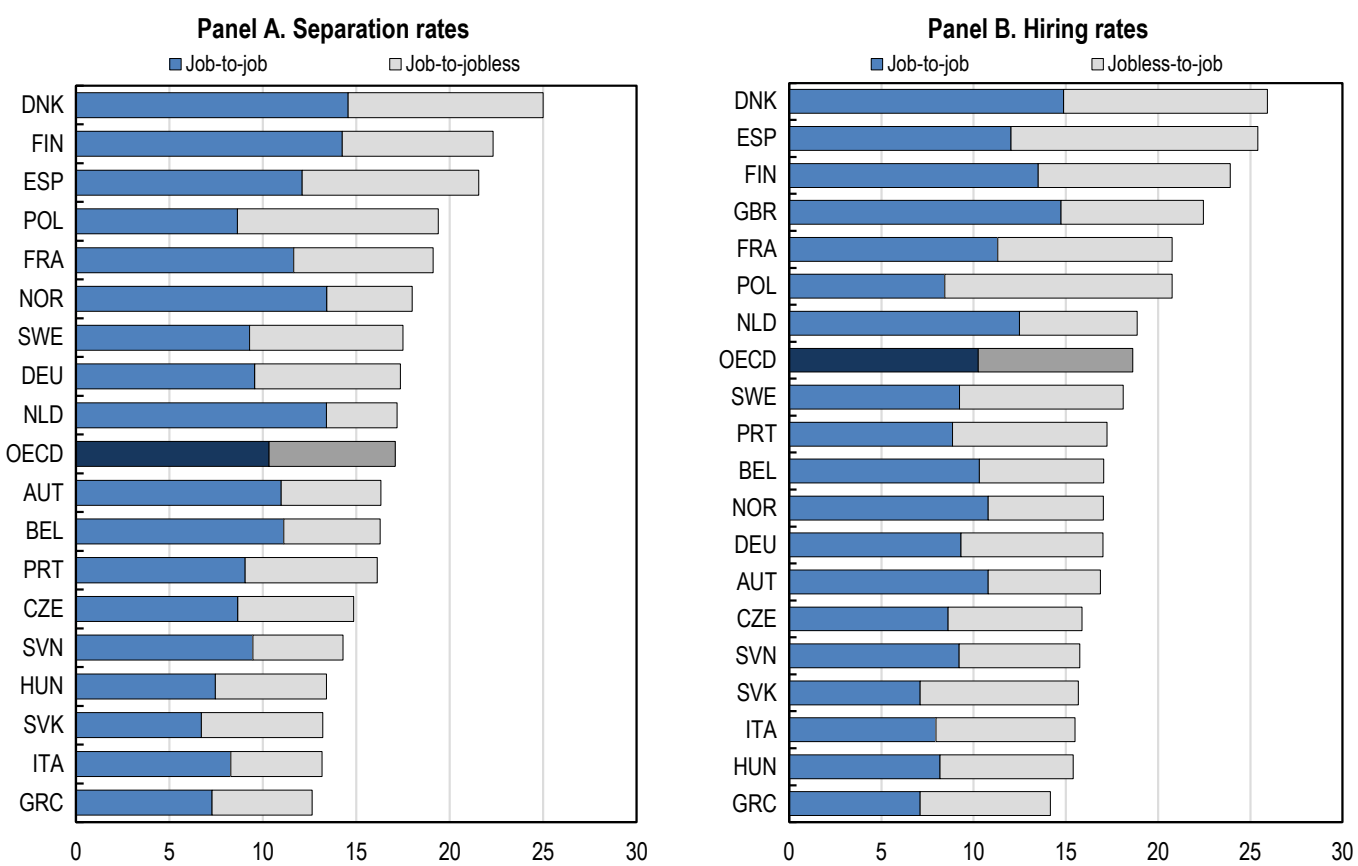

Note: Country average rates for 2000 to 2007 are expressed in percentages and adjusted for industry composition. OECD is the simple average of the countries depicted.

Source: OECD (2010), "Institutional and Policy Determinants of Labour Market Flows", in OECD Employment Outlook 2010: Moving beyond the Jobs Crisis.

\subsection{Household panel data}

44. Earnings and disposable income data are based on household surveys. This study combines several surveys to increase coverage both across countries and over time. Appendix A summarises the data availability of the harmonised household surveys across OECD countries (Figure A1 in Appendix A). The data set represents a fairly large panel of individual earning and household disposable income growth data across 26 OECD countries from 1994 through 2010. Box 3 reviews the three main volatility estimators that are usually used to measure volatility in micro-panels (Garda and Ziemann, 2014).

\section{Box 3. Measures of income volatility in micro-panels}

Microeconomic stability of households and individuals can be assessed by different measures. Household consumption growth volatility is the measure most closely related to welfare (Section 2). Due to the lack of harmonised cross-county data for individual household consumption, personal earnings or household disposable income are used. Figure 10 illustrates how different components of income sum up to household disposable income.

Figure 10. The link between earnings and income variables

Hours worked *

Hourly earnings

$=$ Individual

labour income

\begin{tabular}{|c|}
\hline $\begin{array}{c}\text { Labour earnings and } \\
\text { self-employment income } \\
\text { (Head of household) }\end{array}$ \\
\hline $\begin{array}{c}\text { Labour earnings and } \\
\text { self-employment income } \\
\text { (other members) }\end{array}$ \\
\hline
\end{tabular}
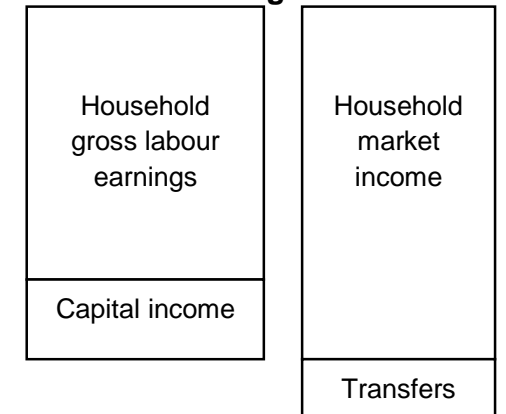

Taxes

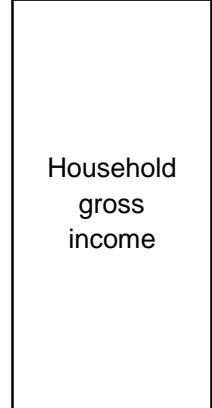

Household disposable income 
ECO/WKP(2015)19

\section{Box 3. Measures of income volatility in micro-panels (cont.)}

Several micro-panels covering household income for a wide range of OECD countries are available:

- $\quad$ The European Community Household Panel (ECHP) covering 15 European countries from 1992 to 2000.

- $\quad$ The European Union Statistics on Income and Living Conditions (EU-SILC) covering 23 European countries from 2002 to 2010.

- The Cross-National Equivalent File (CNEF) covering Canada, Germany, Korea, the United Kingdom, the United States and Switzerland from 1968 to 2008.

Joining the three databases yields a large panel of individual earnings and household disposable income data across 27 OECD countries. One major difficulty when using these panels in the context of analysing volatility is the rotation structure of these panels and attrition. Indeed, the coverage of the panel decreases substantially if one requires several consecutive observations per individual or household in order to obtain a stream of growth rates for which the standard deviation as a measure of volatility can be calculated (see Figure A2 in Appendix A). Against this backdrop, several estimators have been proposed in the literature. At the individual or household level, three estimators are commonly used, all of which require longitudinal data on earnings for individuals and based on year-toyear changes. At the country-level these measures are (see also Garda and Ziemann, 2014):

- Rolling window measure: earnings volatility is calculated for each individual as the standard deviation of year-to-year earnings growth over several consecutive periods (here, three years). An overall measure of earnings volatility for a country or sub-group (for example, a sector) is then calculated as the average of the individuals' standard deviations.

- Incidence of large changes: an individual is defined as having volatile earnings if she experiences a large increase or decrease (here, of at least $20 \%$ ) in earnings from one year to the next. The country measure of earnings volatility can then be calculated as the proportion of individuals in a particular country with volatile earnings.

- Cross-sectional measure: earnings volatility is measured as the cross-sectional standard deviation of yearto-year earnings changes. The idea is that higher earnings volatility should appear as a higher dispersion of year-to-year changes.

By imposing more or less structure on the volatility measure, the three estimators reflect different trade-offs between model and estimation risk. The large incidence measure assumes homogenous average growth rates within and across countries and time which minimizes the estimation risk at the cost of high model risk. On the contrary, the rolling-window measure imposes no structure on the classical standard deviation estimator at the cost of high estimation risk as only very few estimators per window and individual are available. The cross-sectional measure sits somewhere in-between as it takes into account that countries grow at different growth rates and that growth varies over time (average growth rates per year and country need to be estimated).

The various volatility measures exhibit very tight correlation (Table 1).

Table 1. Correlation of different volatility measures

\begin{tabular}{lcc}
\hline & Rolling window & Incidence 20\% changes \\
\hline & \multicolumn{2}{c}{ Disposable income } \\
\hline $\begin{array}{l}\text { Incidence 20\% } \\
\text { changes }\end{array}$ & $0.84^{* \star *}$ & -- \\
Cross-sectional & $0.90^{* * *}$ & $0.79^{* * *}$ \\
\hline \multicolumn{2}{c}{ Labour income } \\
\hline $\begin{array}{l}\text { Incidence 20\% } \\
\text { changes }\end{array}$ & $0.74^{\star * *}$ & -- \\
Cross-sectional & $0.76^{* * *}$ & $0.90^{* * *}$ \\
\hline
\end{tabular}

Source: Income and earnings growth data from 1994 through 2010 based on harmonised national household surveys (CNEF, EUSILC, ECHP). Three stars $\left({ }^{* \star *}\right)$ denote statistical significance at the $1 \%$ level. 


\section{Box 3. Measures of income volatility in micro-panels (cont.)}

Percentage changes in income from one year to the next are calculated as arc-percentages, in line with the literature on micro-level volatility. The arc-percentage change in earnings is equal to the change in earnings from one year to the next divided by average earnings over the two-year period. This choice avoids infinite increases and ensures a symmetric treatment of increases from nothing to something (+200\%) and the reverse $(-200 \%)$.

Nominal income changes are adjusted for inflation using annual consumer price inflation data from the OECD Main Economic Indicators database.

All the measures take into account workers, male or female, aged between 25 and 59 years old, and exclude students, the disabled and retired people. Household measures (mainly disposable income) relate only to households with a head aged between 25 and 59 years old, excluding students, the disabled and retired people. Only households with constant household size are considered.

45. Changes in individual labour income ${ }^{4}$ can either reflect changes in hours worked or hourly earnings (Figure 11). To disentangle these two sources of volatility, individual earnings are decomposed into annual hours worked and hourly earnings.

46. Employment volatility is defined throughout this study as the volatility of annual hours worked. Regrettably, household surveys only provide information at annual frequency for this measure. Accordingly, it is not possible to disentangle changes in working time from changes due to transitions from employment to unemployment and vice versa. Employment volatility is expressed in percentage points with respect to a full-time job (assumed at 2000 hours per annum). For instance, a number of $10 \%$ corresponds to a change of 200 hours irrespective of the initial level of hours worked.

Figure 11. Cross-country differences in annual hours worked and hourly earnings volatility

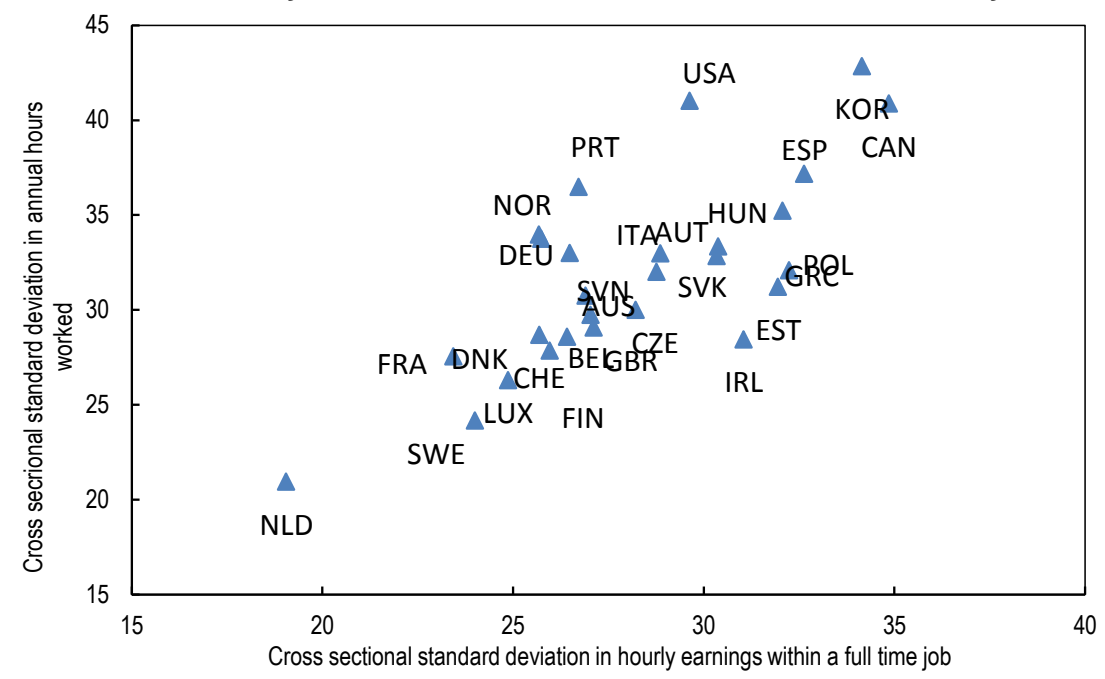

Note: All values refer to country averages. To reflect different coverage across time (see Appendix A), observed volatilities are corrected for year-fixed effects.

Source: Calculations based on EU-SILC, ECHP and CNEF household surveys.

4. Note that labour income includes self-employment income (Figure 7). The CNEF database does not allow disentangling dependent employees from self-employed, so that the contribution of the latter to the standard deviation cannot be isolated. 
47. The volatility measure for hourly earnings includes only full-time workers to quantify changes in hourly earnings in a way that is robust to errors in the measurement of hours worked. The full-time sample is obtained by restricting the sample to individuals working at least 1800 hours in both years. Percentage changes in earnings from one year to the next are calculated as an arc-percentage. That is, the percentage change in earnings is equal to the earnings differential between two years divided by the average earnings for the two-year period. The measure of volatility in hourly earnings excludes arc percentage changes of more than $100 \%$ in absolute terms (multiplication or division by three from one year to the next). In contrast, the measure of volatility in hours worked keeps large changes, as they can have a strong influence on welfare, particularly as they often reflect unemployment spells. Nominal earnings changes are adjusted for inflation using annual consumer price inflation data from the OECD Main Economic Indicators database.

48. Worker reallocation is positively linked with the volatility of annual hours worked (Figure 12). The volatility of hourly earnings growth on the other hand shows no clear relationship with labour reallocation.

Figure 12. Relationship between worker reallocation and earnings volatility
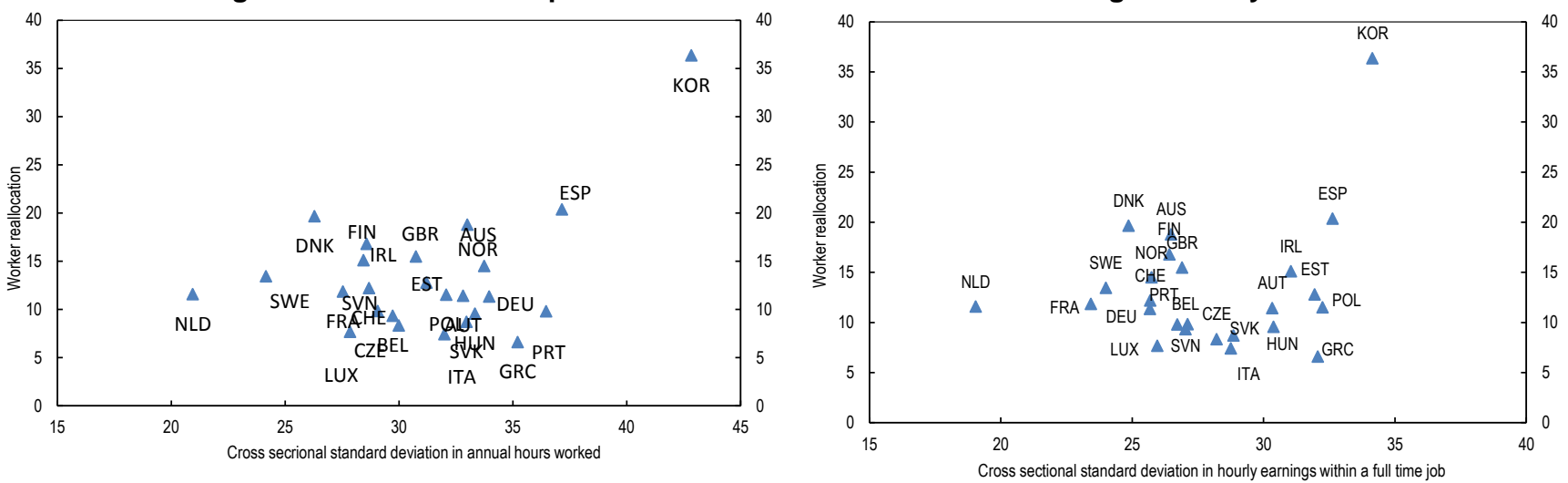

Note: All values refer to country averages. To reflect different coverage over time (Appendix A), observed volatilities are corrected for year-fixed effects.

Source: Calculations based on OECD Labour Force surveys and household panels (CNEF, EU-SILC, ECHP).

\section{The links between economic policies and microeconomic volatility}

49. This section discusses the links between microeconomic volatility and economic policies and institutions according to the framework presented in Section 3. The volatility measures presented in Section 4 serve as dependent variables, while a set of policy indicators is used as explanatory variables (Appendix B). Each of the volatility measures addresses a specific module of the framework (Box 2), which helps to disentangle the different transmission channels of microeconomic volatility.

50. The baseline specification is a standard reduced-form model of institutional determinants of microeconomic volatility at the country level:

$$
\sigma_{c t}=\alpha+\sum_{i=1}^{I} \varphi_{i} \mathrm{P}_{c t}^{i}+\delta_{c}+\delta_{t}+\varepsilon_{c t}
$$

where $\sigma_{c t}$ is one of the three volatility measures for changes in annual hours worked or hourly earnings (Box 3) or worker reallocation (Section 3.1) in country $c$ at time $t, \mathrm{P}_{c t}^{i}$ the policy indicator $i$ in country $c$ at time $t .{ }^{5}$ Finally, $\delta_{c}$ and $\delta_{t}$ denote country and time-fixed effects, respectively.

5. Appendix B gives a flavour of how the policy indicators vary across countries and over time. 
51. A second specification is estimated on the micro data at the level of households and individuals to take into account the effect of their characteristics. Garda and Ziemann (2014) have shown that employment and earnings growth volatility are significantly correlated with age, education and the level of income. In addition, this micro-level specification allows for interactions of these characteristics with policies to investigate the marginal impacts of policies on certain groups of workers:

$$
\sigma_{n c t}=\alpha+\sum_{j=1}^{J} \gamma_{j} C_{n t}^{j}+\sum_{j=1}^{J} \sum_{i=1}^{I}\left(\varphi_{i}+\phi_{i j} C_{n t}^{j}\right) P_{c t}^{i}+\delta_{c}+\delta_{t}+\varepsilon_{n c t}
$$

where $\mathrm{C}_{n t}^{j}$ represents characteristic $j$ such as age, education or level of income of individual $n$ at time $t$. Volatility $\sigma_{n c t}$ refers to the incidence of $20 \%$ changes of annual hours worked or to rolling-window volatility observed at the household level. Cross-sectional standard deviations cannot be used for this specification as it defines volatility at the country level (see Box 3 for definitions of volatility measures).

52. Some of the policy indicators are likely to interact non-linearly with the volatility indicators. Accordingly, the equations include quadratic terms of the policy indicators. This allows for linear, increasing, declining, hump-shaped and U-shaped relationships between volatility and policies.

\subsection{Labour income volatility}

53. The regression analysis will distinguish between two different sources of labour income volatility: employment volatility and hourly earnings volatility. Three dependent variables are defined: i) employment volatility assessed through worker reallocation (see Section 4.1 for the definition); ii) volatility of changes in annual hours worked; iii) and the volatility of hourly earnings growth on a fulltime job (see Box 3 for the definition of volatility measures using these variables).

54. The first part of the results refers to the country-level specification (1) and uses country-year estimates of micro-level volatility (Box 3). The second part refers to the micro-level specification (2) and uses individual characteristics included in the household surveys.

\section{Country-level specification}

55. Table 2 depicts the estimated relationships derived from panel regressions between policies and different components of earnings volatility. The table shows the main results using the measure of crosssectional standard deviation for annual hours worked and hourly earnings. However, results are robust to the measure chosen. Appendix $\mathrm{C}$ presents the results in greater detail using the three measures.

56. Hump-shaped relationships mean that competitive policy settings (low values of the policy indicator) and restrictive ones (high values of the policy indicator) are both associated with low volatility while intermediate settings are associated with high volatility. Humps typically reflect a positive value for the linear coefficient and a negative value for the squared term coefficient. One example for such a relationship is employment protection legislation (see Table $\mathrm{C} 1$ in Appendix C). Humps mean that the relationship goes up and down within the observed range of parameters. When the estimated relationship is non-linear but monotonic within the range of observed parameter values, it is depicted as in the last row of Table 2 (and the first and second rows of Table 4). 
Table 2. Links between policies and labour income volatility

Employment protection (regular workers)
Centralisation of wage bargaining
Generosity of unemployment benefits
Active labour market policies
Product market regulation
Credit intermediation

Note: The shapes indicate the estimated relationship between policy estimators (rows) and volatility estimates for different aggregates of labour income volatility (columns). Volatility of annual hours worked and hourly earnings are measured with cross-sectional standard deviation. Humps indicate that the estimated link is non-monotonic within observed parameter values. Curvy lines such as in the bottom row indicate that the estimated link is non-linear but monotonic within observed parameter values. Empty cells signify that the estimated coefficients are not significant at the $10 \%$ level (see Tables C1 and C2 in Appendix C for detailed regression coefficients, significance levels and results using the three measures of volatility). Stars show confidence levels for the linear and squared term: ${ }^{* *}$ stands for $99 \%,{ }^{* *}$ for $95 \%$ and ${ }^{*}$ for $90 \%$. If significance differs between the linear and squared terms, the lower level is shown.

Source: OECD calculations using CNEF, ECHP and EU-SILC and OECD statistics.

57. The analysis shows a hump-shaped link between employment protection legislation for regular workers (EPL) and all indicators of labour market related microeconomic volatility (Table 2). This finding suggests that the improvement in labour allocation, greater economic dynamism and stronger potential growth associated with easing tight EPL, documented in OECD (2006), initially comes at the cost of greater economic volatility for individuals. It corroborates earlier OECD work showing that relaxing EPL increases worker reallocation (OECD, 2010; Bassanini et al., 2010) and extends the result to the volatility of hours worked and hourly earnings. The present finding complements earlier results by documenting that, when EPL is further relaxed, worker reallocation and the volatilities of hours worked and hourly earnings all tend to decline. This second effect underscores the benefits of fluid labour markets: compared with tight or moderately restrictive policy settings, more deregulated labour markets bring larger growth benefits and greater stability.

58. The estimates suggest that in economies with stringent levels of employment protection ${ }^{6}$ such as the Czech Republic, Germany, Greece, Italy, Portugal, Slovenia and Sweden a gradual deregulation could raise labour income volatility by increasing both employment and labour earnings volatility. One particular example of a reform which overcame the reform trap is the case of Estonia in 2009 (Figure 13). ${ }^{7}$ Estonia relaxed its EPL in 2009, which reduced the EPL indicator from highly regulated (above the critical value) to medium regulated (below the critical value). The associated decrease in hourly earnings volatility was a bit higher than suggested by the estimates, but the estimation suggests that a weaker reform could have led to higher volatility. However, one caveat is that only one year of data is available after the reform.

6. These are countries with EPL above the estimated critical value, which is slightly above the OECD average.

7. Estonia introduced comprehensive changes to EPL, reducing the notice period and the amount of severance payments pertaining to regular contracts, which took effect in July 2009. 
Figure 13. Hourly earnings volatility decreased after Estonia greatly reduced employment protection

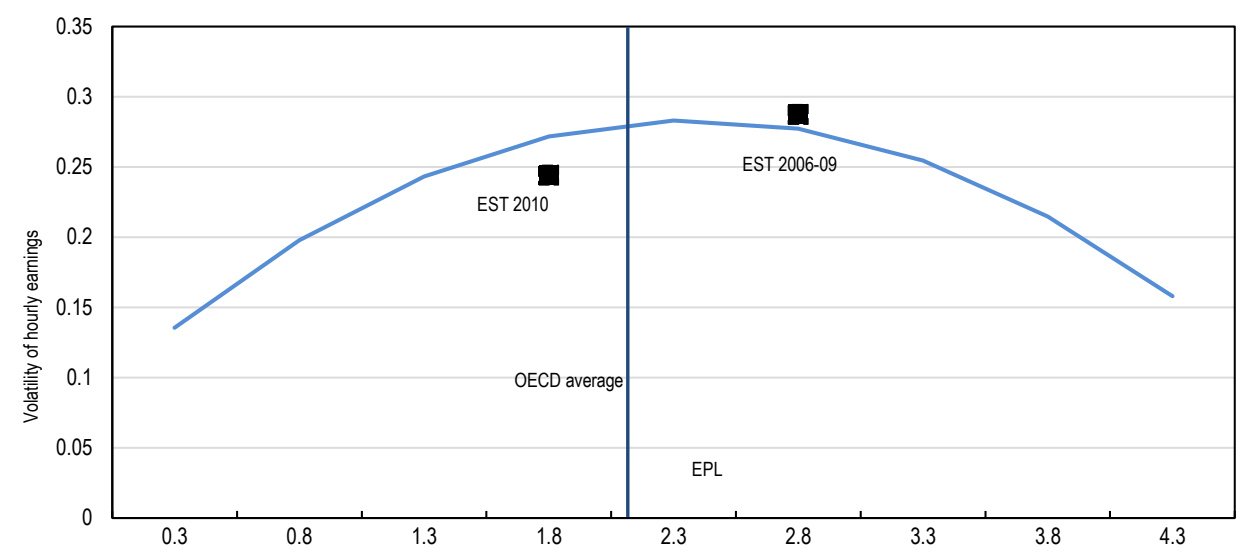

Note: The curve shows the estimated relationship between the volatility of hourly earnings and EPL, based on the estimates in Table C2 in Appendix C). Volatility of hourly earnings is measured using the cross-sectional standard deviation. Rectangles are data for Estonia pre-reform (average 2006-09) and post-reform (2010). The vertical line shows the OECD average for the EPL indicator for 2010.

Source: OECD calculations using CNEF, ECHP and EU-SILC and OECD statistics.

59. More generous unemployment insurance, here measured by gross replacement rates, is associated with higher volatility of both hours worked and hourly earnings. Unemployment benefits can increase the reservation wages preventing the unemployed from reintegrating the labour market causing higher changes in annual hours worked. This result is in line with previous empirical evidence (OECD, 2010) indicating that higher levels of unemployment benefits amplify the adverse labour market impacts of economic downturns by increasing the persistence of unemployment. The positive link between unemployment benefit levels and microeconomic volatility may reflect that strong unemployment insurance enables risk taking in the labour market (OECD, 2010).

60. Centralisation of wage bargaining is found to have a hump-shaped relationship with the two components of labour earnings volatility: annual hours worked and hourly earnings. Intermediate values for centralisation of wage bargaining favour high volatility of annual hours worked and hourly earnings. By contrast, completely decentralised or fully centralised wage bargaining systems exhibit low volatility of working time or hourly earnings. This association may reflect benefits from internalising negative externalities in centralised systems (Bassanini and Duval, 2006) and benefits from flexible and tailored negotiations at the plant level in decentralised systems (OECD, 2012). In contrast to labour and product market regulations, there is little evidence that a particular wage bargaining system is more conducive to economic growth than another (OECD, 2004).

61. Spending on active labour market programmes seems to reduce worker reallocation. However, this result is not robust across specifications. ALMPs are expected to increase the probability of reemployment of workers by increasing hirings. At the same time, by training workers during unemployment and improving the matching process ALMPs are expected to decrease separations. The total impact on worker reallocation seems to favour the decrease in separations and hence worker reallocation. This net effect suggests that ALMPs seem effective at improving the quality of labour-market matches, thereby reducing unnecessary worker reallocation.

62. Policies not directly relating to the labour market also appear to influence labour earnings volatility (Table 2). Easing product market regulations (PMR) to instil greater competition is associated with an initial increase in the volatility of hours worked when starting from a very stringent stance. However, the relationship then changes with hours worked becoming more stable when product-market regulations are further relaxed to make settings very pro-competitive. 
63. Credit deepening is initially associated with lower volatility (Table 2), presumably because it enables firm-level smoothing, which in turn drives down labour-market volatility. Testing directly for such firm-level smoothing could be a valuable extension of the current finding. At high levels of credit intermediation (more than $90 \%$ of GDP), however, the link flattens, suggesting that the smoothing effects of greater credit availability saturate.

\section{Micro-level specification}

64. The use of household panels permits controlling for age, education and the income level of individuals, all of which have been found to influence earnings volatility (Garda and Ziemann, 2014). Accordingly, specification (2) is used to capture direct and indirect impacts of individual characteristics. The results indicate that young, male, low-income workers suffer from the highest volatility of annual hours worked and hourly earnings.

65. The results from the micro-panel regressions confirm the results obtained at the country level. Employment protection and the centralisation of wage bargaining yield a hump-shaped relationship with the volatility of hours worked and hourly earnings. The credit intermediation ratio affects the volatility negatively and with a decreasing slope. Product market regulation has a hump-shaped impact on the volatility of annual hours worked and no impact on that of hourly earnings.

66. Young workers generally experience a higher volatility of working time and hourly earnings than others (Figure 14). More generally, economic policies affect different age groups quite differently. Younger workers are also more affected by labour market institutions as the slope and shape of the relationship with EPL and ALMPs are more pronounced for the volatility of annual hours worked (lower panel in Figure 14). This is in line with the fact that young workers have a higher propensity to change jobs and are therefore more affected by labour-market frictions. Product market regulation and the credit intermediation ratio have also a differential impact by age, being stronger for younger workers.

67. More educated workers have lower hourly earnings volatility. By contrast, the volatility of annual hours worked is the same across educational groups. Moreover, the impact of economic policies does not differ for the various educational groups (Figure 15).

68. Income levels also matter for volatility and how policies influence it. ${ }^{8}$ Low-income workers experience the greatest volatility in hourly earnings. Economic policies have different effects on employment volatility depending on workers' income levels (Figure 16). ALMPs have their greatest effects on working time and hourly earnings for low-income workers. The results suggest that ALMPs help under- and unemployed people to integrate the labour market. Deregulating product markets increases the volatility of hourly earnings for low-income workers but not for others. Conversely, more generous unemployment benefit systems generally seem to result in higher volatility of hourly earnings except for the lowest incomes. This hints at the presence of dual or segmented labour markets as low-income workers are more likely to occupy temporary or atypical jobs characterised by lower bargaining power than permanent contract workers. ${ }^{9}$

8. For each year, income quartiles are constructed based on the average income over the years that enter the volatility measure (i.e. $\mathrm{t}$ and $\mathrm{t}-1$ for large changes and $\mathrm{t}, \mathrm{t}-1, \mathrm{t}-2$ and $\mathrm{t}-3$ for 3 -year rolling window volatility). The dataset used to calculate the volatility of annual hours worked also includes workers who are under- or unemployed while the panel for hourly earnings is restricted to full-time workers. As a result, the first income quartile in part reflects unemployment or under-employed workers while the second quartile mainly comprises low-income workers.

9. This is reminiscent of the insider-outsider model (Lindbeck and Snower, 1986). 
Figure 14. Impact of structural policies on labour income volatility by age group

$$
\diamond-\text { age }=25 \quad \square-\text { age }=45 \quad \cdots \Delta \cdots \text { age }=59
$$

Panel A: Probability of large changes in hourly earnings
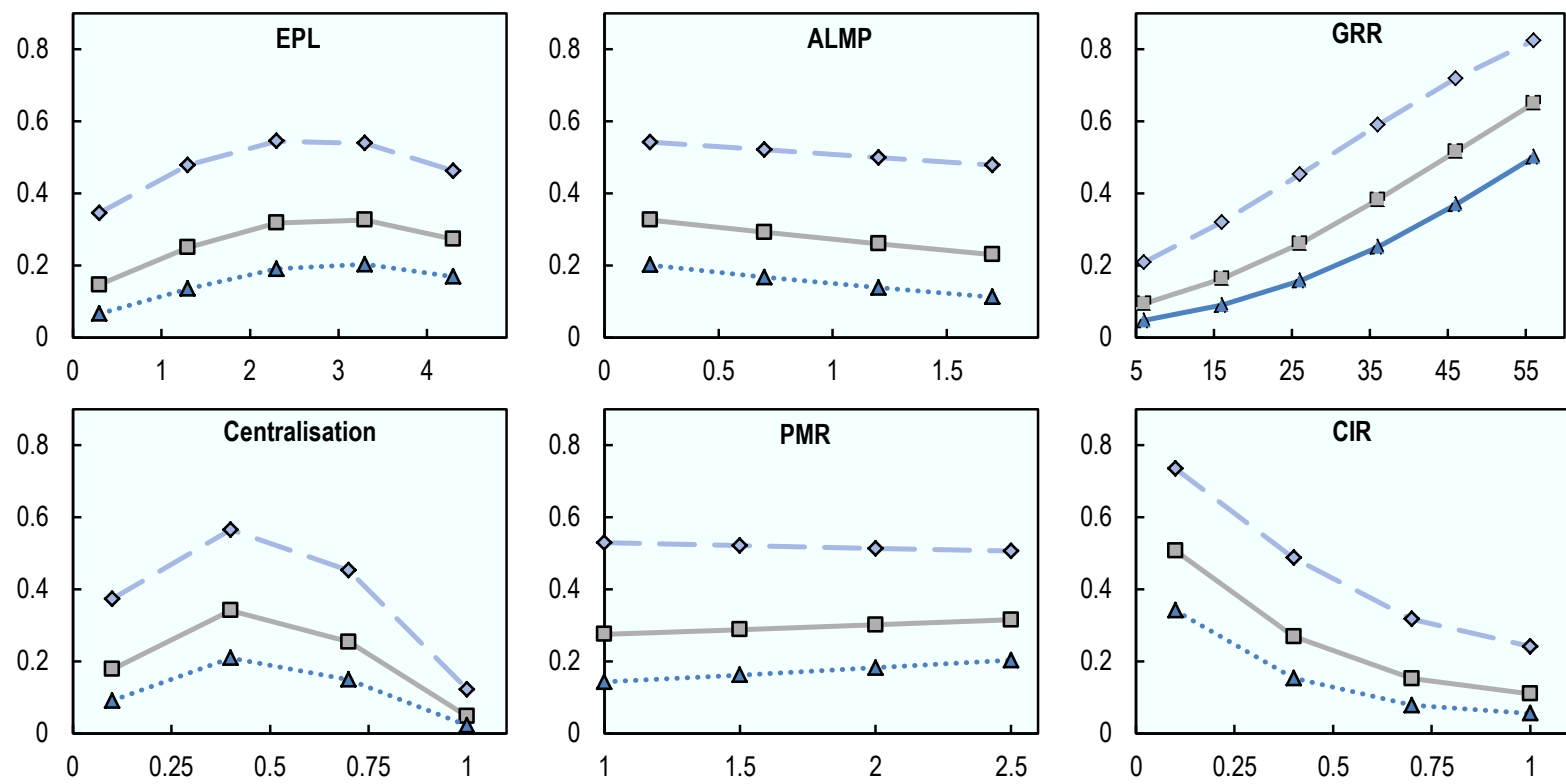

Panel B: Probability of large changes in annual hours worked
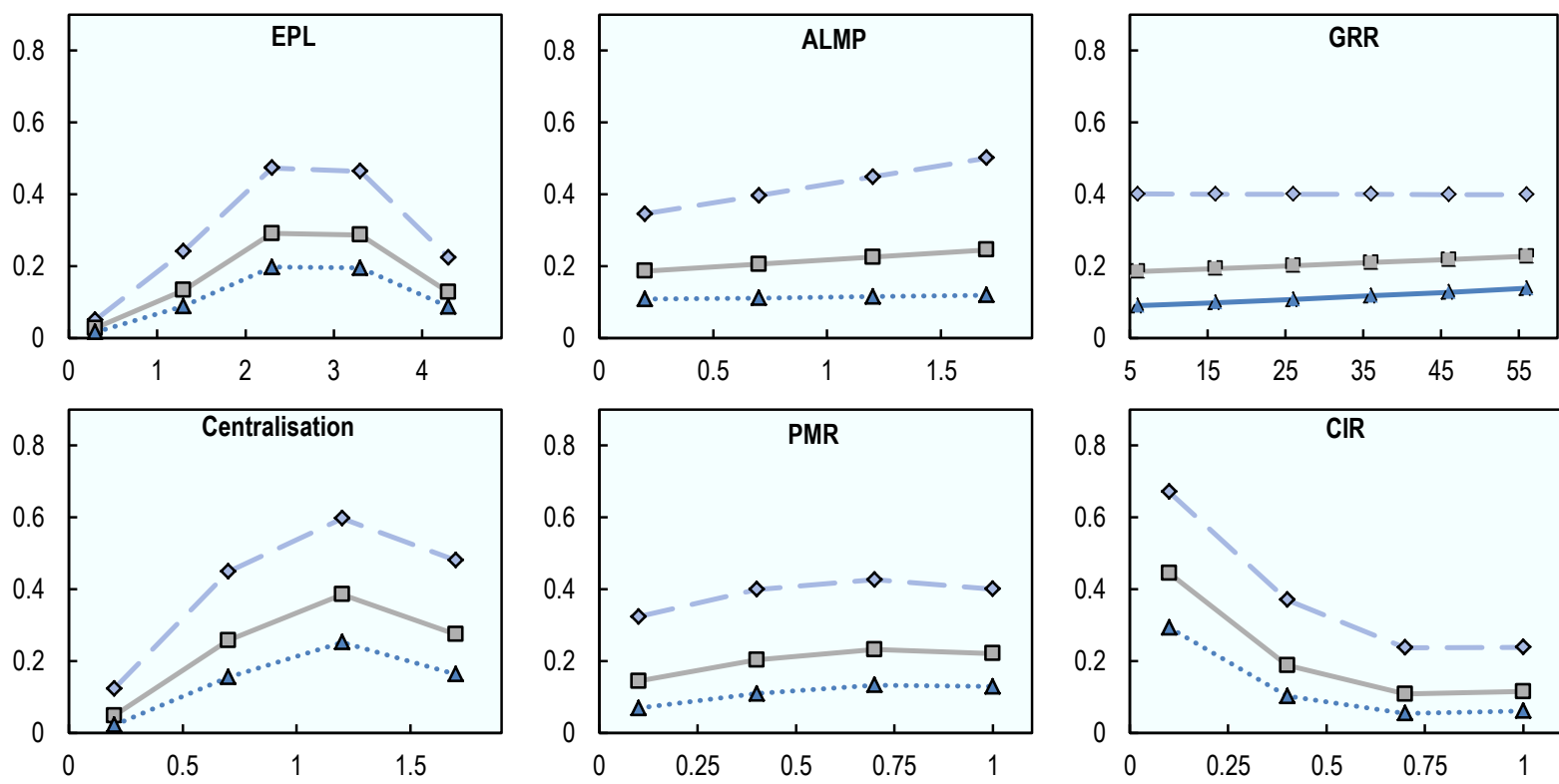

Note: The graphs plot the predicted margins derived from panel regression coefficients. Refer to table C3 in Appendix C for detailed coefficient estimates.

Source: Calculations based on CNEF, ECHP and EU-SILC. 
Figure 15. Impact of structural policies on labour income volatility by level of education - less than high school $\square$ high school $\cdots \Delta$... more than high school

Panel A: Probability of large changes in hourly earnings
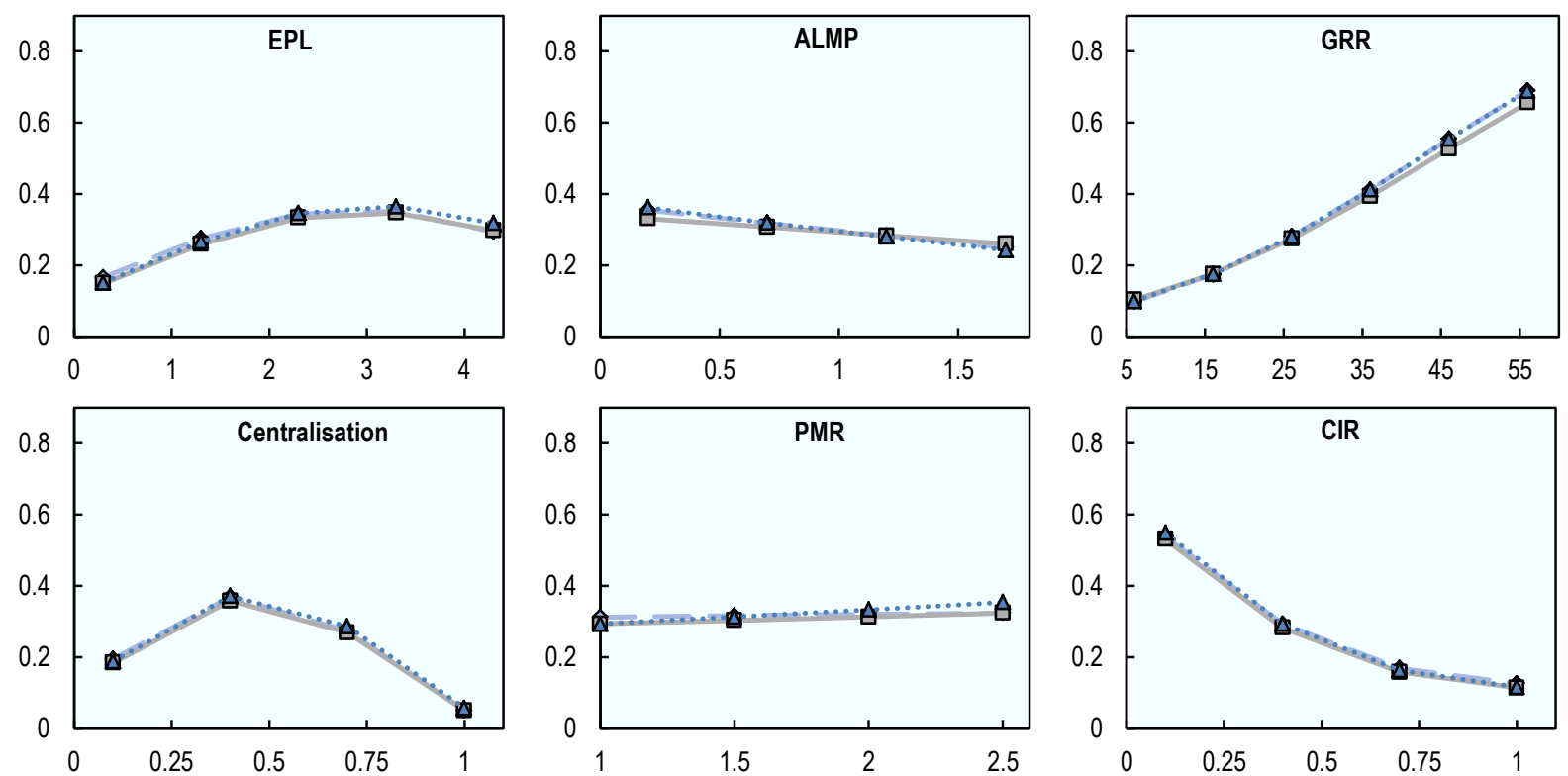

Panel B: Probability of large changes in annual hours worked
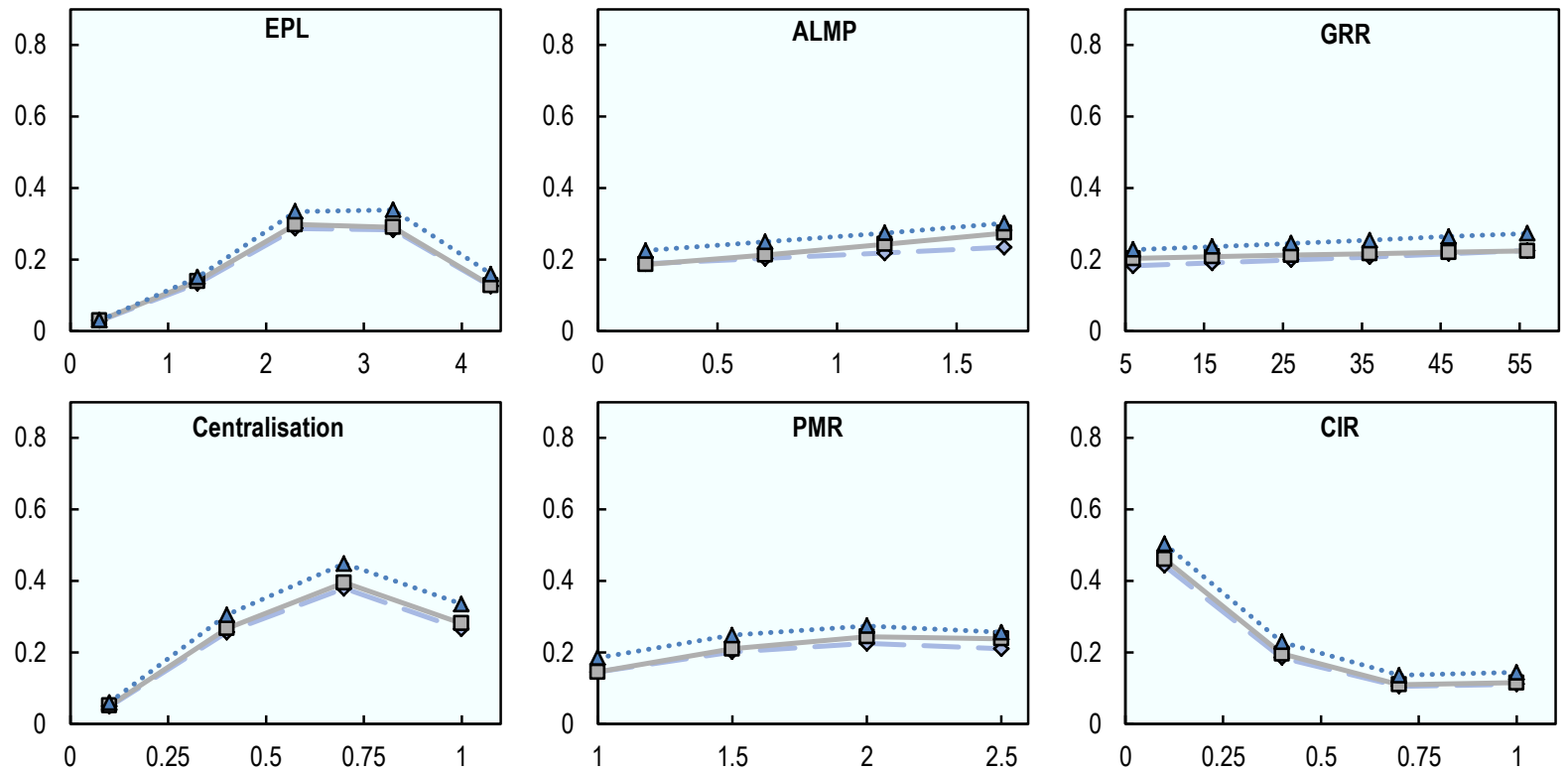

Note: The graphs plot the predicted margins derived from panel regression coefficients. Refer to table C3 in Appendix C for detailed coefficient estimates.

Source: Calculations based on CNEF, ECHP and EU-SILC; OECD. 
Figure 16. Impact of structural policies on labour income volatility by level of income ¿-Bottom quartile $\quad \square$ Second quartile $\quad \cdots \Delta \cdots$ Third quartile

Panel A: Probability of large changes in hourly earnings
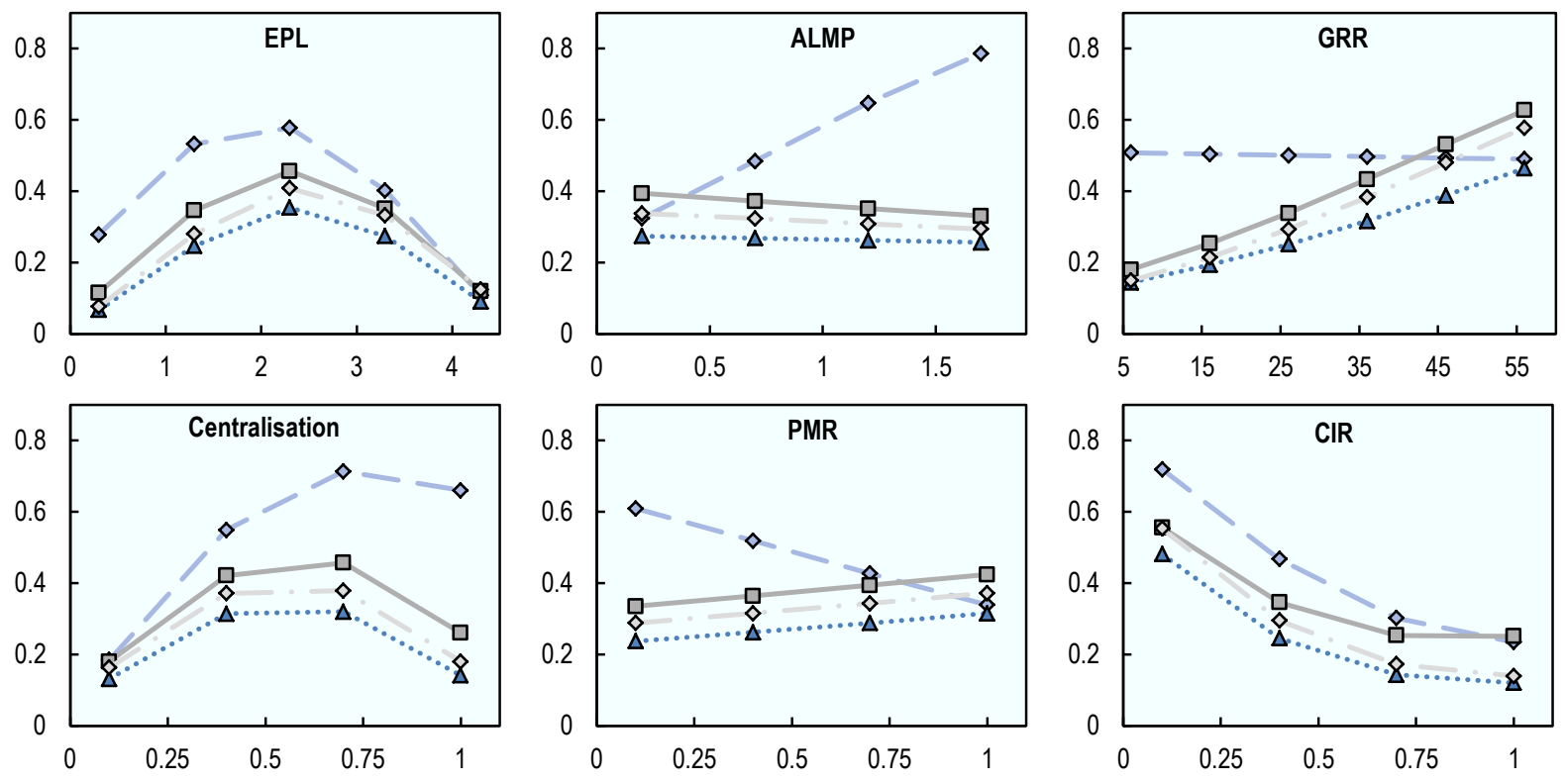

Panel B: Probability of large changes in annual hours worked
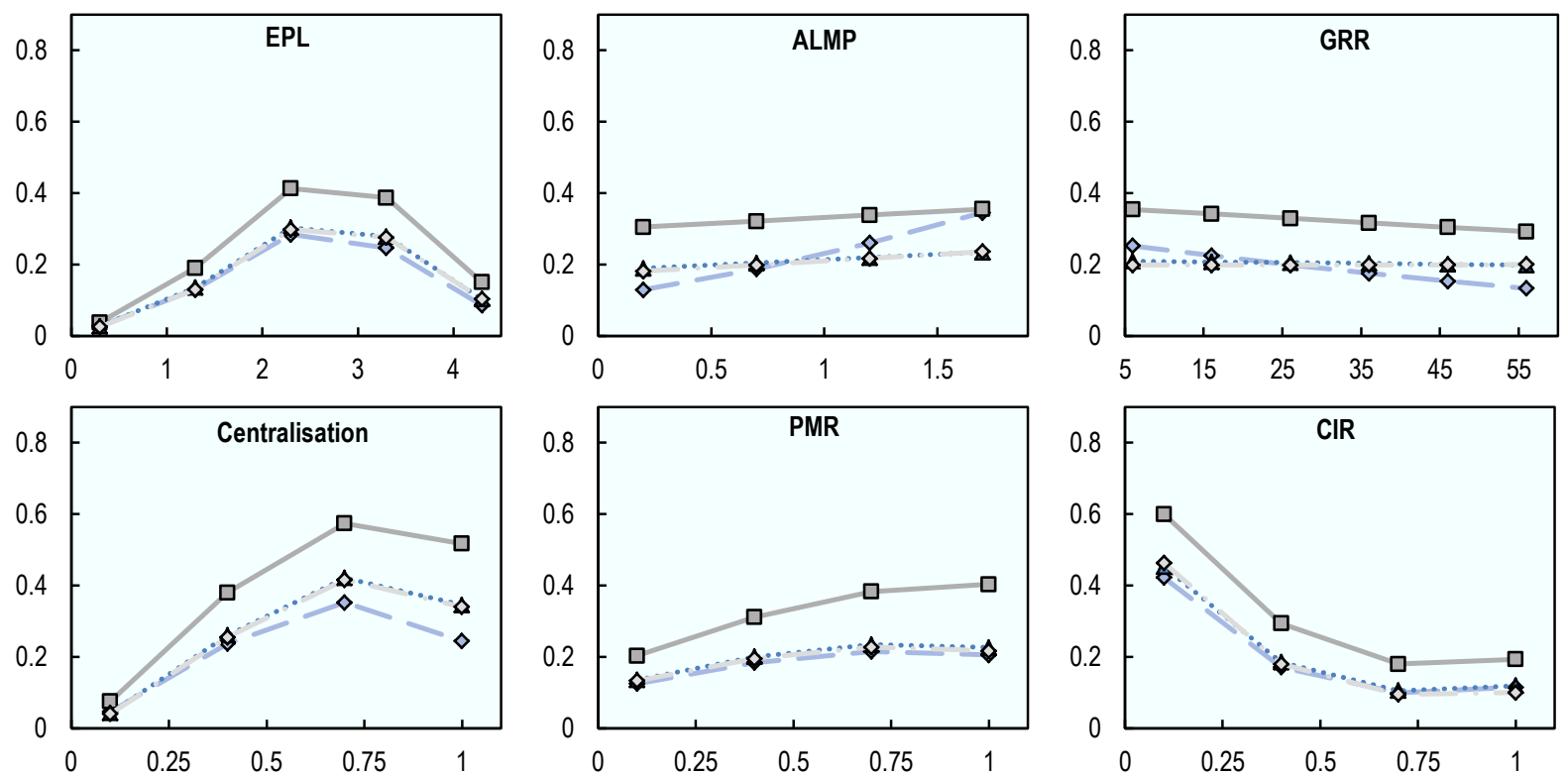

Note: The graphs plot the predicted margins derived from panel regression coefficients. Refer to table C3 in Appendix C for detailed coefficient estimates.

Source: Calculations based on CNEF, ECHP and EU-SILC.

\section{Investigating causality through sector-level analysis}

69. One caveat of the preceding panel-regression analysis is that the observed correlations do not necessarily reflect causal links between the policy indicators and volatility measures. The framework presented in Section 2 helps to alleviate concerns about spurious correlations or reverse causality as it lays out the channels through which the specific policies are expected to affect income volatility. A way to push the identification mechanism one step further is to exploit sector-level data in the CNEF and ECHP 
datasets. ${ }^{10}$ This sub-section aims at estimating the impact of policies on employment and labour income volatility using a difference-in-difference strategy on industry-level data (Box 4).

\section{Box 4. Using industry data to investigate the effect of policies across countries}

The empirical strategy is based on an approach pioneered by Rajan and Zingales (1998). It reflects the idea that the influence of a particular economic policy is greater in industries in which the policy is more likely to affect the firm's behaviour, the so called "policy-binding industries". To identify the "policy-binding" sectors, a so-called benchmark indicator needs to be identified. This benchmark should be defined in the economy where the policy is the least stringent, with the assumption that it proxies for the technological and market driven firm behaviour across industries in the absence of policy-induced costs.

For example, in their seminal paper Rajan and Zingales (1998) use the dependence on external finance in the United States across sectors as a benchmark variable to study the impact of financial development on economic growth across countries. The idea is that sectors that are more dependent on external finance (the policy-binding industries) should be the ones benefitting the most from financial development and thus enjoy higher growth.

This strategy is a difference-in-difference estimation and has the advantage that it controls for policies or institutions that influence the volatility in the same way in all industries. More precisely, all factors and policies that can be assumed to have, on average, the same effect on volatility in policy-binding industries as in other industries can be controlled for by country dummies. The general specification is as follows:

$$
\sigma_{\mathrm{cj}}=\alpha+\varphi \mathrm{B}_{\mathrm{j}} \mathrm{P}_{\mathrm{c}}+\beta \mathrm{X}_{\mathrm{cj}}+\delta_{\mathrm{c}}+\delta_{\mathrm{j}}+\varepsilon_{\mathrm{cj}}
$$

where $P_{c}$ is the policy indicator in country $c, B_{j}$ is the benchmark in industry $j, X_{c j}$ are additional country-sector characteristics and $\delta_{\mathrm{c}}$ and $\delta_{\mathrm{j}}$ represent country and industry fixed effects, respectively, which are included to capture additional confounding factors. The parameter of interest is $\varphi$. The greater this parameter is, the greater the relative effect of the policy under analysis in binding industries will be with respect to non-binding industries. The sign of $\varphi$ also provides an indication of the direction of the average effect of the policy, subject to the identifying assumption that in non-binding industries this effect is either of the same sign and smaller or zero. In line with the strategy in Section 3, quadratic terms of the policies are introduced (as long as these were significant in the previous analysis) to address non-linearities in the relationships.

This equation is estimated for two different policies, but using only one at a time: employment protection legislation (EPL) and product market regulation (PMR). The policy benchmarks identified in the present study are: ${ }^{1}$

- Worker reallocation for EPL: Employment protection is more likely to be binding in industries that have a high propensity of hirings and separations as EPL taxes the labour adjustment margin of firms. Accordingly, similar to Bassanini et al. (2010), worker reallocation in US industries is used as a benchmark to identify the effect of EPL on labour income volatility across industries.

- $\quad$ Firm entry and exit rates for PMR: Klapper, Laeven and Rajan (2006) provide "natural" entry and exit rates for US sectors. The higher the "natural" rate of entry and exit, the higher the costs of complying with bureaucratic requirements and the higher the potential restrictive impact of stringent product market regulation.

1. Dependence on external finance in US industries has also been identified as a benchmark for credit intermediation ratio. However, problems arising when matching databases at the sector level resulted in the loss of many industries and countries and hence not enough data points to have reliable estimates.

70. The results shown in Figure 17 confirm the hump-shaped relationship between the level of employment protection legislation and labour income volatility (measured by the incidence of large changes in hourly earnings and annual hours worked). EPL has a larger impact on labour income volatility

10. This approach has been implemented for a panel of nine countries (AUT, BEL, CAN, DEU, DNK, FRA, GBR, IRL, PRT) based on ECHP and CNEF data for the period 1994-2000 and 13 sectors. The longitudinal data in SILC does not include sector information. 
in binding sectors that is in sectors with higher rates of worker reallocation. On the other hand, labour income volatility in non-binding sectors is much less affected by EPL. The finding that the hump-shaped relationship originates from EPL-binding sectors clearly points to a causal link.

\section{Figure 17. Earnings volatility and EPL in binding and non-binding industries}
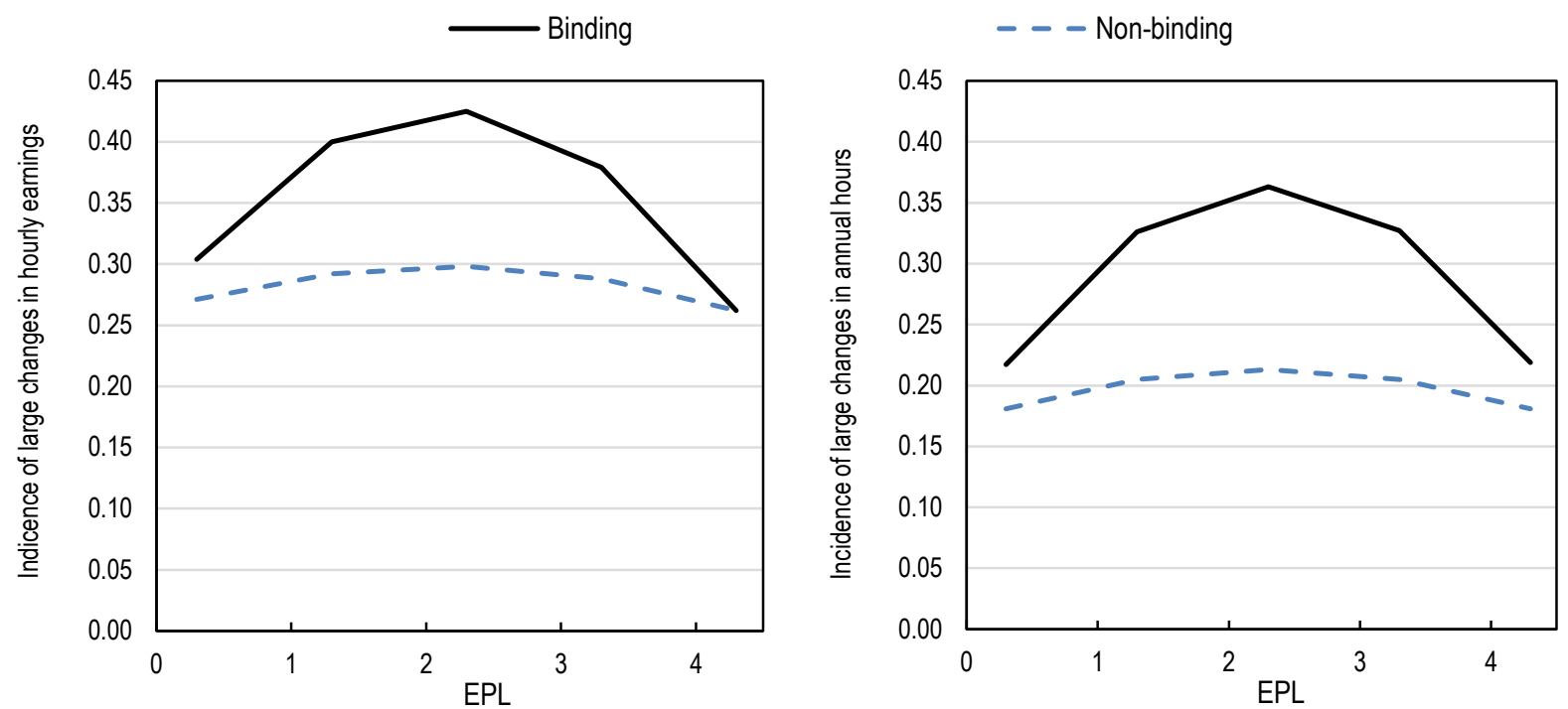

Notes: The graphs plot the incidence of large changes derived from the specification in Box 4. See Table C6 in Appendix C for detailed regression results. The data span from 1994 to 2000. Policy binding industries are defined using the benchmark, which is the worker reallocation rate in US industries.

Source: Based on CNEF and ECHP for sector level volatility measures and Bassanini (2010) "Institutional Determinants of Worker Flows: A Cross-Country/Cross-Industry Approach", OECD Social, Employment and Migration Working Papers, No. 107, for benchmark worker reallocation rates from US industries.

71. Figure 18 also confirms the results from the previous subsection for PMR. Product market regulation has a hump-shaped effect on annual hours worked volatility while there is no effect on hourly earnings. Figure 18 shows that PMR has a larger impact on hours worked volatility in binding sectors, that is, in sectors with a higher natural rate of firm entry, while it is not significant in non-binding sectors.

Figure 18. Earnings volatility and PMR in binding and non-binding industries
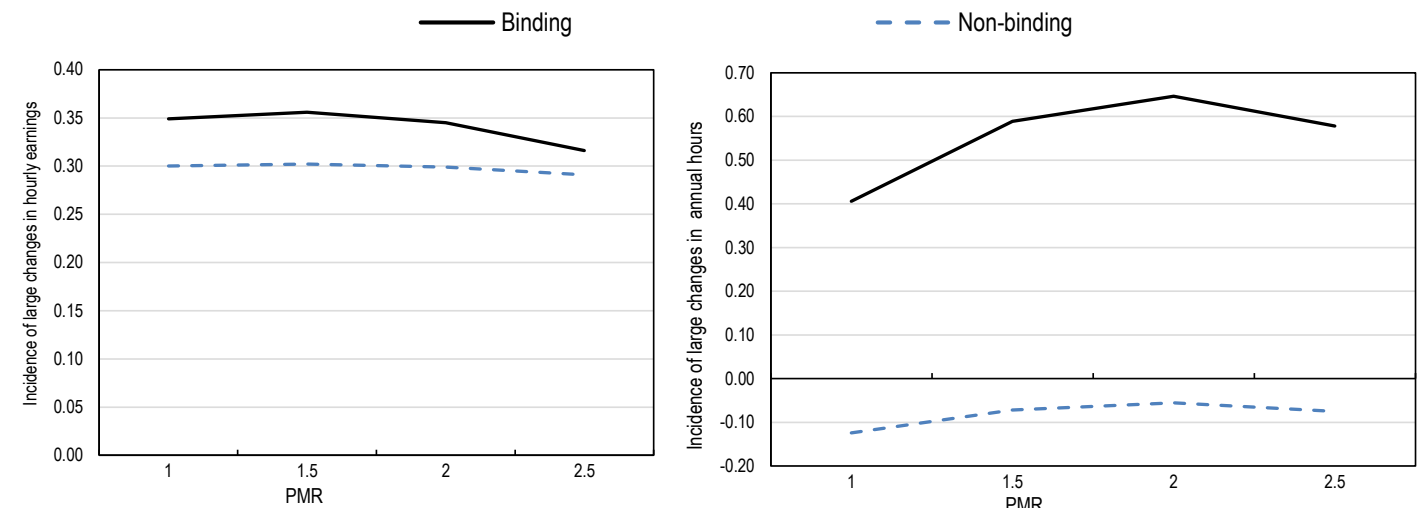

Notes: The graphs plot the incidence of large changes derived from the specification in Box 4. See Table C6 in Appendix C for detailed regression results. The data span from 1994 to 2000. Policy binding industries are defined using the benchmark, which is the firm entry rate in US industries.

Source: Based on CNEF and ECHP for sector level volatility measures and Klapper et al. (2006) "Entry Regulation as a Barrier to Entrepreneurship", Journal of Financial Economics, Vol. 82, No. 3, pp. 591-629 for benchmark firm rates for US industries. 


\subsection{Capital income volatility}

72. Household market earnings comprise income from capital as well as labour. Capital income volatility is very high, much higher than labour and disposable income volatility (Figure 19). Furthermore, countries with high capital income volatility tend to have somewhat higher labour and disposable income volatility. Capital income volatility is measured at the household rather than individual level because capital income often cannot be attributed to a particular household member, in contrast with labour income.

73. However, the high volatility of capital income does not matter very much for overall volatility. The reason is that capital income makes up only $5 \%$ of household market income according to the surveys used to measure microeconomic volatility. However, these surveys are likely to underestimate capital income, in particular because the quality of the data is lower for high-income earners, who also happen to hold a disproportionate share of capital. Indeed, the national accounts, which provide a more accurate measure of aggregate household income, put the share of capital income at $8 \%$. But even an $8 \%$ share would also mean that capital income volatility cannot meaningfully influence overall income volatility. However, the true share is likely to be greater because neither the national accounts nor surveys include capital gains as part of capital income. Capital gains are likely to be both large in size and much more volatile than dividends and interest payments, suggesting that the real contribution of capital to total income volatility might be large, although this hypothesis remains speculative in the absence of data.

74. Capital income volatility can also be related to economic policies (Figure 20). Estimates of household-level capital income volatility are generally lower in countries that tax personal income more progressively. This link could reflect that, when personal income tax is highly progressive, greater income variability leads to a higher tax bill. Households plausibly have greater control over the smoothness of their capital income stream, especially excluding capital gains, and may buy more financial products providing more stable returns in countries with more progressive personal income taxation.

Figure 19. Capital income volatility is higher than labour and disposable income volatility
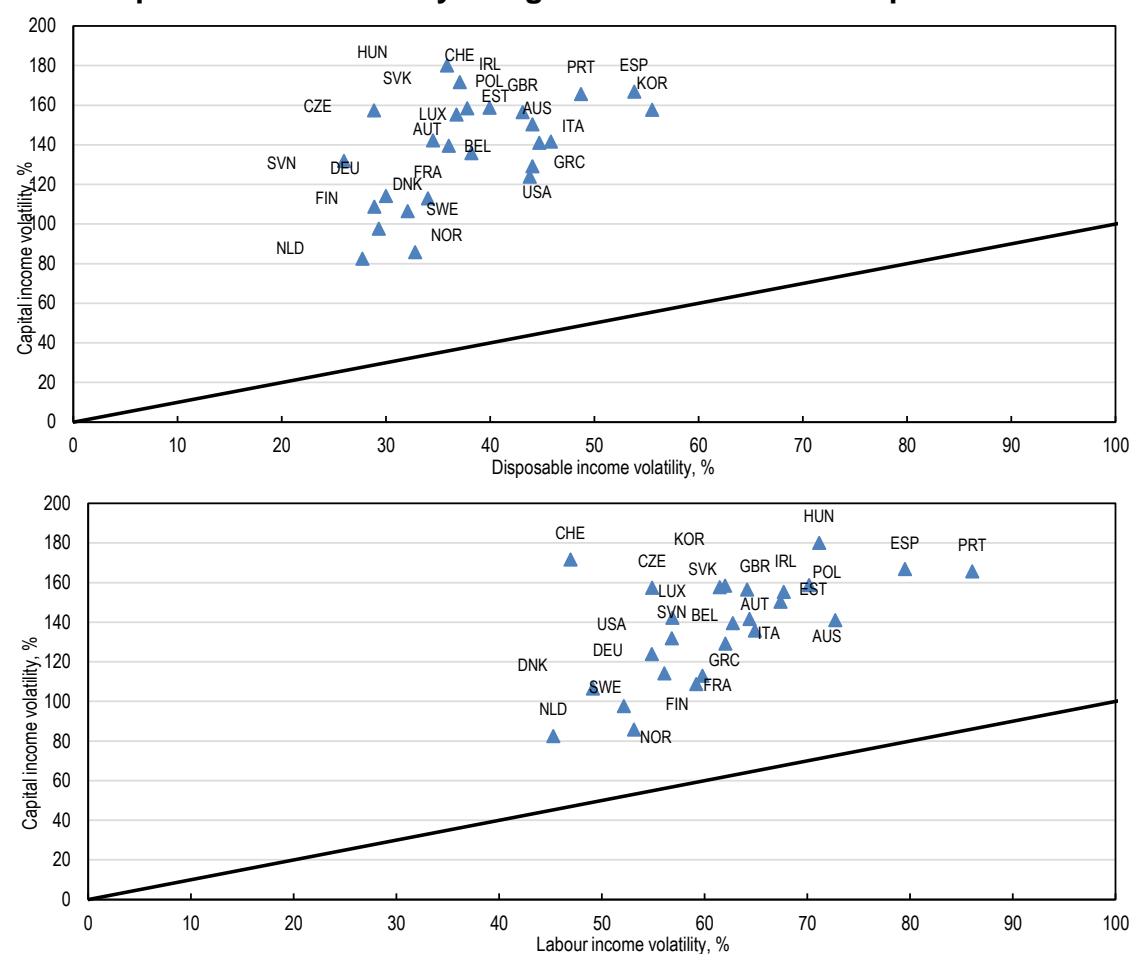

Notes: Volatility is the cross-sectional standard deviation of capital, labour and disposable income growth across households at the country level. Figures averages are for the period 2005-10.

Source: CNEF, SILC and ECHP. 
Figure 20. Capital income is less volatile in countries with more progressive taxation

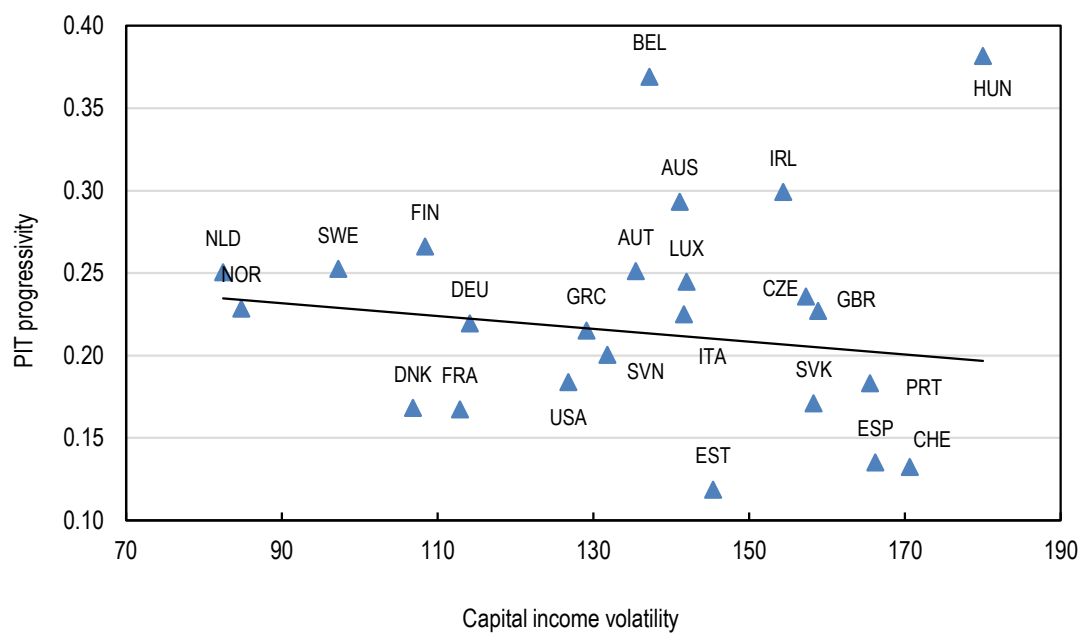

Note: Volatility is the cross-sectional standard deviation of capital income growth across households at the country level. The personal income tax (PIT) progressivity is measured as the percentage increase in net income when gross wage earnings increase by one currency unit, i.e. the elasticity of after-tax income with respect to pre-tax gross wage income. The elasticity is calculated as [1-(1-METR) / (1-AETR)] where the marginal effective tax rate (METR) is the marginal PIT rate plus employee social security contributions less cash benefits and the average effective tax rate (AETR) is the average PIT rate plus employee social security contributions less cash benefits. The more progressive the system is, the higher this elasticity will be. Data points are for averages for the period 2005-2010.

Source: CNEF, SILC and ECHP, OECD Tax Database and OECD calculations.

\subsection{Disposable income volatility}

75. A decomposition of disposable income into its components highlights cross-country heterogeneity in the way changes in individual earnings pass through to household income. Figure 21 shows how an increase or decrease in individual gross labour earnings of $20 \%$ or more affects household disposable income in selected OECD countries. Panel A is for the period 1994-2000 and panel B for the period 2005-10, which includes the economic crisis.

76. In all countries, disposable income is partially shielded from the full impact of large changes in individual earnings. Social transfers and taxes dampen the impact of swings in earnings on household disposable income. Taxes yielded a larger attenuation effect than transfers during the period 1994-2000 in all countries. In contrast, during 2005-10, transfers became more important for attenuating the large decline in individual labour income in Norway, Luxemburg, France and Canada.

77. Transfers play a significant but generally more limited role than taxes. This finding could raise a policy trade-off with inequality (discussed in Section 6.3), since cash transfers are more effective in reducing inequality in most OECD countries than taxes (Hoeller et al., 2014). This contrast reflects that progressive taxation responds strongly to income changes while transfers are primarily determined by income levels (or not connected to income).

78. The income of other household members also plays an important role in smoothing disposable income, especially in Italy, Korea and Slovenia over the period 2005-10. On the other hand, capital income plays little role in attenuating or amplifying shocks to labour earnings. As discussed earlier, even if capital income variations are more pronounced than those of labour and disposable income its weight in disposable income is very small. 
79. The main factors that attenuate the transmission of large declines in labour income into household disposable income (Figure 21, bottom panel) vary across country groups:

- Changes in the labour income of other household's members appear to be the most important smoothing instrument in southern European countries. They offset more than $25 \%$ of the reduction in the income of the household head. Taxes were also an important buffer, as they provided an offset of $15 \%$, while that provided by transfers was only $5 \%$.

- In the Nordic countries, other household members, labour income, taxes and transfers play a similar role in smoothing this reduction contributing each about $10 \%$.

80. Further, the attenuation effect varies considerably across countries. For the Nordic countries and the Netherlands, in $60 \%$ of the cases a large shock to disposable income can be avoided after having experienced a large earnings shock (bars in Figure 22). This translates into an attenuation of the size of the shock passed to disposable income of more than 60\% (triangles in Figure 22).

81. On the other hand, the probability of avoiding a large shock in disposable income after experiencing a large shock to labour earnings reaches only 35\% in most Southern (Spain, Greece and Italy) and Eastern European (Estonia, Slovakia, and Poland) countries as well as in Korea, and most English speaking countries (Australia, Canada, the United Kingdom and the United States).

82. Taxes and transfers reduce disposable income volatility. The size of the impact depends on the size, mix and progressivity of each component of the tax and cash transfer system. A progressive income tax and benefit system reduces volatility because it reduces tax obligations, and increases cash transfers, more than one for one when market income falls.

83. The attenuation impact of the tax system can be considered along three dimensions: i) the size effect, measured by total taxes over GDP; ii) the tax mix since some taxes could have a greater effect on volatility than others, measured by the share of the tax under consideration (personal income, consumption, property, and social contributions) in total tax receipts and iii) personal income tax progressivity.

84. Furthermore, the ability to smooth the impact of swings in income also depends on the different dimensions of the cash transfer system. As before: i) the size effect is measured by the ratio of transfers to GDP, ii) the cash transfer mix is measured by the share the specific cash transfer (unemployment benefits, family benefits and active labour market programmes) in total cash transfers and iii) the progressivity of unemployment benefits and other cash transfers. 
Figure 21. Contributions to changes in household disposable income Panel A: Period 1994-2000

Individuals with at least $20 \%$ increase in labour earnings

$\square$ Taxes $\square \mathrm{K}$ inc $\quad \square$ Transfers $\quad \square$ Indiv labour earnings $\square$ Other $\mathrm{HH}$ members labour earnings $\Delta$ Disposable income
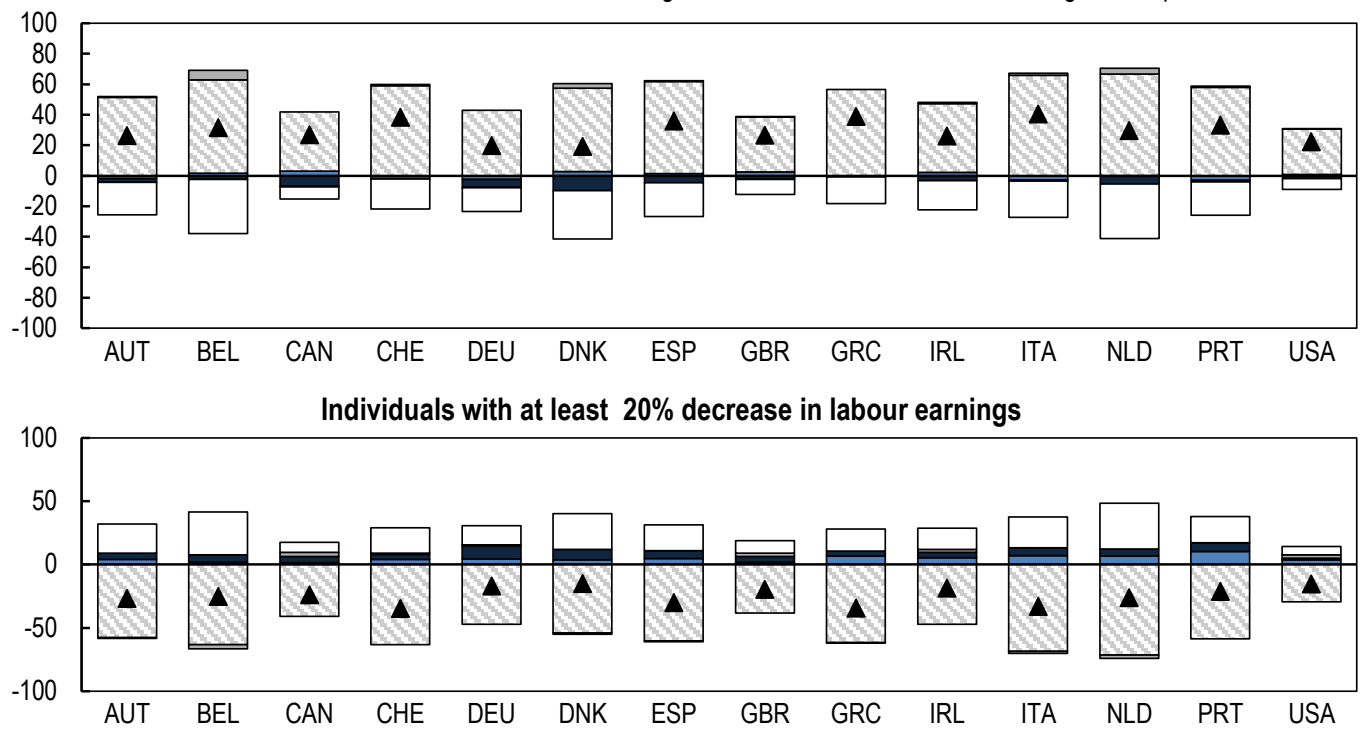

Panel B: Period 2005-2010

Individuals with at least $20 \%$ increase in labour earnings
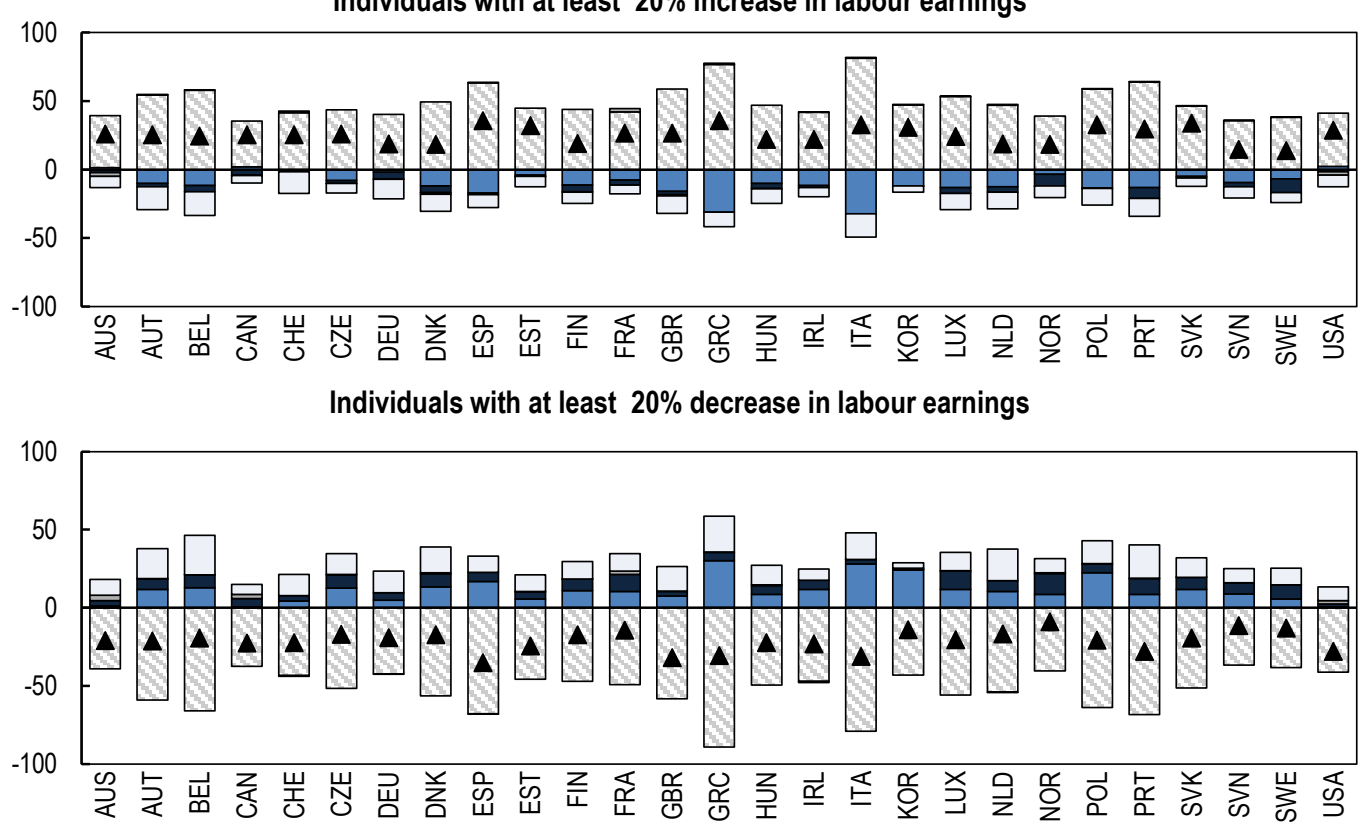

Note: Percentage changes in income components are calculated as the arc percentage change, i.e. the difference in income between two years, divided by the average income of the two years. The period of coverage is 1994-2000 for panel A (with the exception of Austria 1995-2000; Switzerland 1999-200; Finland 1996-2000; and USA 1994-96); for panel B it is 2005-10 (with the exception of Australia, Switzerland, Germany, Ireland 2005-08; Slovak Republic and Sweden 2005-09; France and Greece 2007-09; Italy 2007-10, and Korea 2005-07). The estimates shown are for households headed by individuals aged between 25 and 59 years old, and exclude students, disabled and retired people. Only households with constant household size are considered.

Source: Calculations based on CNEF, ECHP, EU-SILC. 
Figure 22. Attenuation of earnings shocks

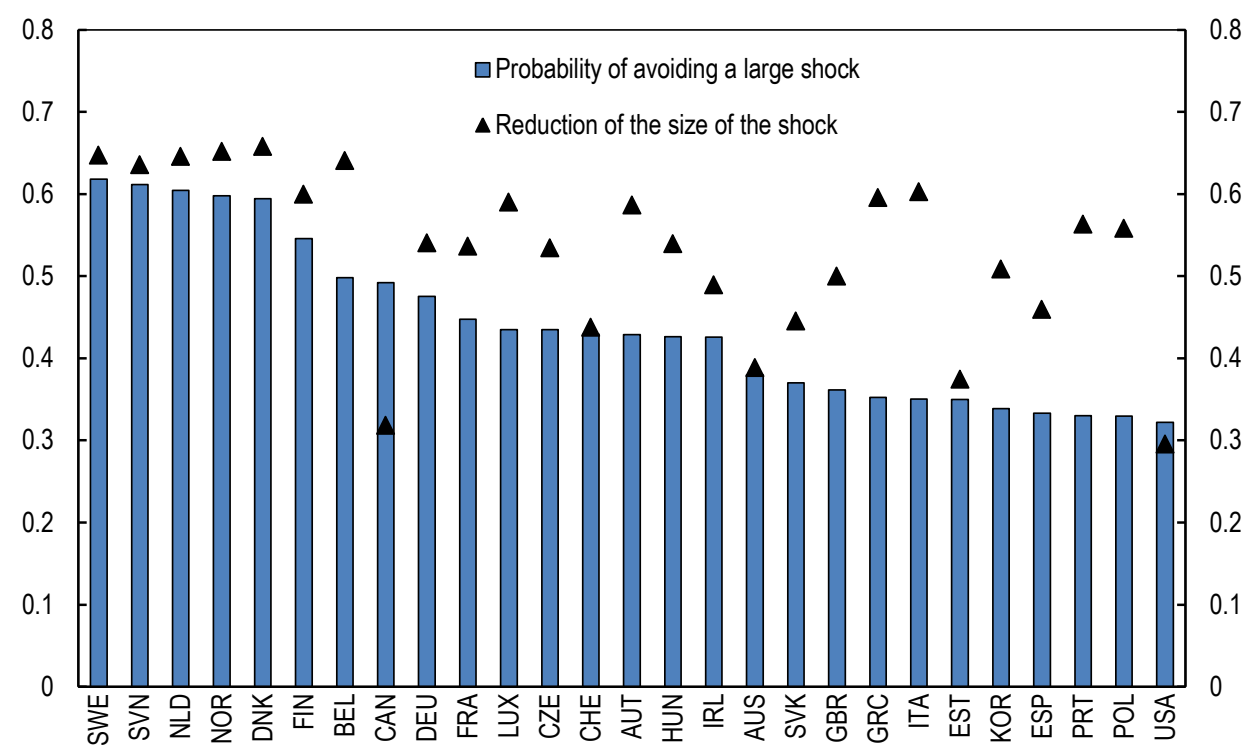

Note: Attenuation is measured as the probability of avoiding a large change in disposable income, which is defined as the proportion of households not experiencing large changes in disposable income conditional on a large change (more than $20 \%$ ) in individual earnings. The measure shows how large changes in individual labour earnings of the household head are attenuated when looking at household disposable income. Numbers refer to averages over the period of 2005-10.

Source: Based on CNEF, ECHP and EU-SILC and OECD calculations.

85. Figure 23 shows standardised policy indicators for the top and bottom quintile of the probability of avoiding large disposable income shocks. ${ }^{11}$ Attenuation is high in the Nordic countries and the Netherlands and low in Korea, Poland, Estonia, Spain, Portugal and the United States. An indicator above zero means the variable is above the OECD average, while below zero means below the average. For example, consumption taxes do not differ between low and high attenuation countries since the indicator has a value of zero, i.e. is at the average. Instead, an indicator with a value of one means that it is one standard deviation above the average.

86. Results indicate that that high attenuation is related to higher cash transfers as a percentage of GDP. With respect of the mix of cash transfers, higher family benefits, unemployment benefits and spending on active labour market policies are associated with a better ability to smooth disposable income shocks from labour earnings shocks. The progressivity of the benefit system is also related to the attenuation capability. Highly progressive cash transfer schemes are better able to weaken the effect of changes in labour earnings on disposable income.

11. Results plotted on Figure 23 remain broadly similar when using a different measure of shock attenuation (i.e. the triangles shown in Figure 22 instead for the bars in the same figure) 
ECO/WKP(2015)19

Figure 23. Tax-and-benefit systems differ between high and low attenuation countries

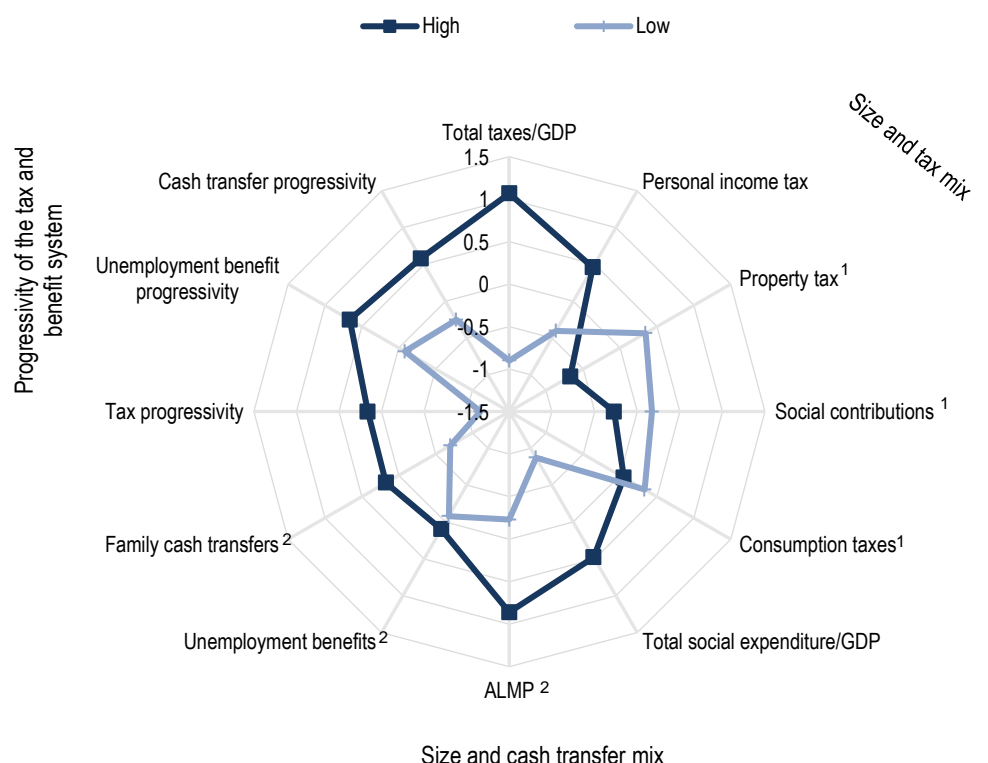

1. As a proportion of total tax revenues.

2. As a proportion of total cash transfers.

Note: Numbers are averages over the period 2005-10. The indicators are standardised to have zero mean and a standard deviation of one across OECD countries for which data are available. A standardised indicator above zero means the variable is above the OECD average. For example, consumption taxes on average do not differ between low- and high-attenuation countries since the indicator has a value of zero. In a polar opposite example, the tax-GDP ratio is one standard deviation above the average in highattenuation countries and almost one standard deviation below in low-attenuation countries. Attenuation of a disposable income shock is defined as the probability of not experiencing large changes in disposable income conditional on a large change (more than $20 \%$ ) in individual labour earnings. High and low refer to the top and bottom 20th percentile of the probability of avoiding large disposable income shocks. For the progressivity of taxes see note below Figure 16. Progressivity of unemployment benefits is defined as the difference in the net replacement rate for low and high earners defined as having earnings equal to 67 and $150 \%$ of the average wage. The larger the difference, the more progressive are unemployment benefits. The progressivity of cash transfers is taken from Hoeller et al. (2014), measured by the Kakwani index. A progressive index means that the cash transfers as a share of individual income is higher at the lower end of the income distribution. Total social expenditure and total taxes are measured as percentages of GDP.

Source: OECD calculations using CNEF, ECHP, EU-SILC and various OECD databases.

87. Higher total taxes are also associated with a stronger attenuation of disposable income shocks. However, the mix of taxes is also important. Countries where the personal income tax is more important are better able to shield disposable income from labour earnings shocks, since they play a crucial role for income and spending decisions of liquidity-constrained households. Instead, a higher share of property taxes and social contributions taxes are associated with lower attenuation. Finally, consumption taxes, which tend to be regressive, do not play an important role. Finally, the role of taxes in the attenuation of disposable income emanates from the progressivity of the income tax. More progressive income tax systems attenuate disposable income shocks more.

\section{Reconciling microeconomic stability, economic growth and inequality}

\subsection{Trade-offs and complementarities between growth and micro-level stability}

88. The results presented above shed light on the possible impact of growth-enhancing reforms generally recommended by the OECD on microeconomic volatility (OECD, 2013b). Some reforms can enhance welfare by improving both growth and stability. Reforms that bring product-market regulation or employment protection from among the tightest to among the most relaxed settings belong to this category. 
89. Other reforms generally recommended to boost growth potential can raise a trade-off with microeconomic volatility. This category includes reforms that aim at boosting long-term growth potential by cutting transfers and reducing progressive income taxes. The above characterisation of high versus low attenuation countries underscored that transfers typically contribute to stabilising disposable income in the face of shocks while consumption taxes, which are not progressive, do not contribute much to stabilisation.

90. Other approaches that may involve trade-offs between long-term growth and microeconomic stability are marginal reforms to product market regulation and employment protection in countries where policy settings in these areas are tight. The non-linear effects identified above indicate that such gradual adjustments from very to moderately tight policy settings are likely to increase microeconomic volatility, although they can also be expected to boost growth. In this regard, countries with tight policy settings can be considered as lying in a reform trap, where marginal reform raises more difficult trade-offs than deeper changes.

91. On the other hand, reforms to reduce unemployment benefit levels could in certain circumstances boost growth and reduce microeconomic instability, although many caveats apply. Estimates reported above indicate that lower unemployment benefits are likely to be accompanied by reduced microeconomic volatility. They can boost growth if they move from a high to a more moderate level. Too deep cuts, however, can harm growth by deteriorating the quality of job matches.

\subsection{Getting closer to a growth-volatility frontier?}

92. Under standard assumptions, households exhibit preferences for high consumption growth and low volatility (Box 5). As the preceding analysis has shown, some growth-enhancing structural reforms, such as relaxing employment protection legislation in overregulated regimes, are also likely to increase the volatility of earnings and hence consumption. Consequently, such reforms may, at least in the short run, confront households with trade-offs between consumption growth and stability with the optimal choice of the policy stance depending on the individual degree of risk aversion.

93. Similar to a risk-return analysis for financial assets, one can illustrate this growth-stability tradeoff by plotting an efficient frontier. The underlying premise is that high instability stemming from social mobility, creative destruction, and productivity-enhancing reallocation should be rewarded by higher per capita growth. Consequently, countries that are not near the efficient frontier are likely to suffer from deficient policy settings that either impede the transmission of volatility into growth or generate harmful excess volatility or do both.

94. The empirical analysis will focus on households. Welfare dynamics can be approximated by a linear combination of average consumption growth and individual consumption growth volatility (Box 5). Consumption growth efficiency would then be measured as the distance to the efficient frontier formed by country-year observations that exhibit optimal trade-offs between consumption growth and volatility (Figure 24). The optimal point on the frontier depends on the individual level of risk aversion. In the absence of comprehensive cross-country household data on consumption, this study approximates the consumption frontier by using disposable income. 
ECO/WKP(2015)19

Figure 24. Growth-volatility frontier

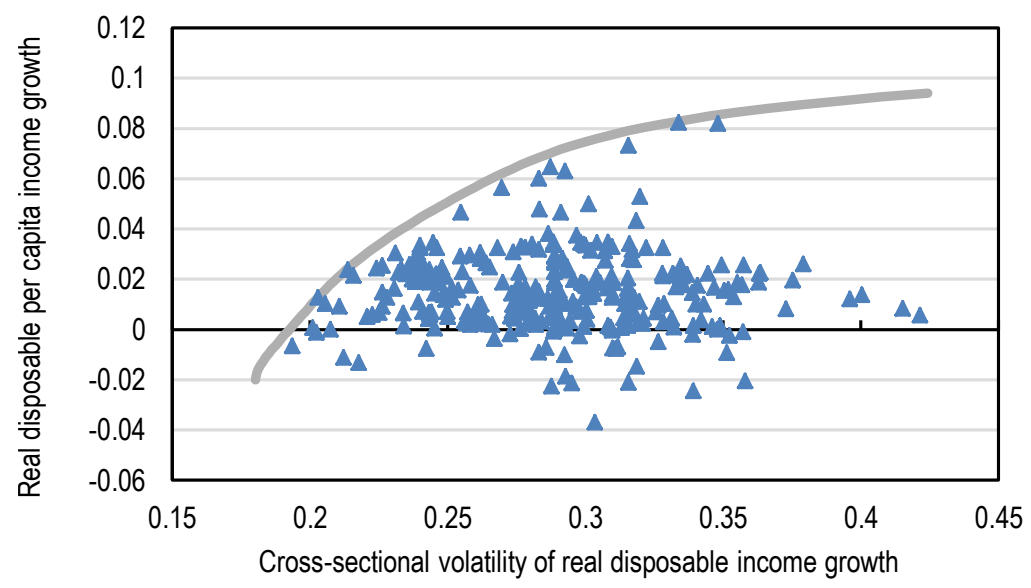

Note: Real per capita disposable income growth is derived from trend disposable income from national accounts deflated by the consumer price index and divided by the number of inhabitants. Households' disposable income growth volatility is measured by the cross-sectional standard deviation of real disposable income growth taken from household surveys. Each triangle corresponds to a country and a year since 1990 .

Source: OECD National Accounts. EU-SILC, ECHP and CNEF household surveys. Authors' calculations.

\section{Box 5. Household welfare and the efficient consumption frontier}

Individual consumers maximize lifetime utility of consumption $C$ subject to the inter-temporal budget constraint depending on wealth $\mathrm{W}$, income $\mathrm{Y}$ and the interest rate $\mathrm{r}$ :

$$
\begin{gathered}
\operatorname{Max} \mathrm{E}_{t} \mathrm{~V}_{t}=\operatorname{Max}_{t}\left\{\sum_{s=0}^{\infty} \beta^{s} U\left(C_{t+s}\right)\right\} \\
\text { s.t. }: W_{t+1}=(1+r) W_{t}+Y_{t}-C_{t}
\end{gathered}
$$

Using the recursive form of the value function $\mathrm{V}$ and the envelope theorem, the first order conditions lead to the well-known Euler equation that describes the optimal consumption paths. For instance, denoting $\beta$ the discount factor, assuming power utility with relative risk aversion $\gamma$, and a constant deterministic risk-free rate $r$, the Euler equation is:

$$
\beta \mathrm{E}_{t}\left\{\left(\frac{C_{t+1}}{C_{t}}\right)^{-\gamma}\right\}(1+r)=1
$$
useful:

Denoting $g_{t}$ the growth rate of consumption between $t$ and $t+1$, the following second order Taylor-expansion is

$$
\left(\frac{C_{t+1}}{C_{t}}\right)^{-\gamma}=\left(1+g_{t}\right)^{-\gamma} \approx 1-\gamma g_{t}+\gamma(\gamma+1) \frac{g_{t}^{2}}{2} .
$$

When $g$ is small, the variance of the growth rate can be approximated by $\sigma^{2}=\mathrm{E}\left(g^{2}\right)-E(g) E(g) \approx \mathrm{E}\left(g^{2}\right)$. The Euler equation for welfare maximization can thus be rewritten as the following quadratic relationship between expected consumption growth $\mu=\mathrm{E}(\mathrm{g})$ and its volatility $\sigma^{2}$ :

$$
\mu \approx c+\frac{1}{2}(\gamma+1) \sigma^{2}
$$

with $\mathrm{c}$ a function of $r, \gamma$ and $\beta$. This relationship can be illustrated by indifference curves (Figure 25). Starting from a given level of consumption, different pairs of expected consumption growth and volatility can yield the same level of expected utility. In order to do so, higher volatility has to be compensated by higher expected consumption growth with the slope of the relationship depending on the level of risk aversion $\gamma$. 
Box 5. Household welfare and the efficient consumption frontier (cont.)

Figure 25. Risk aversion and optimal consumption profiles

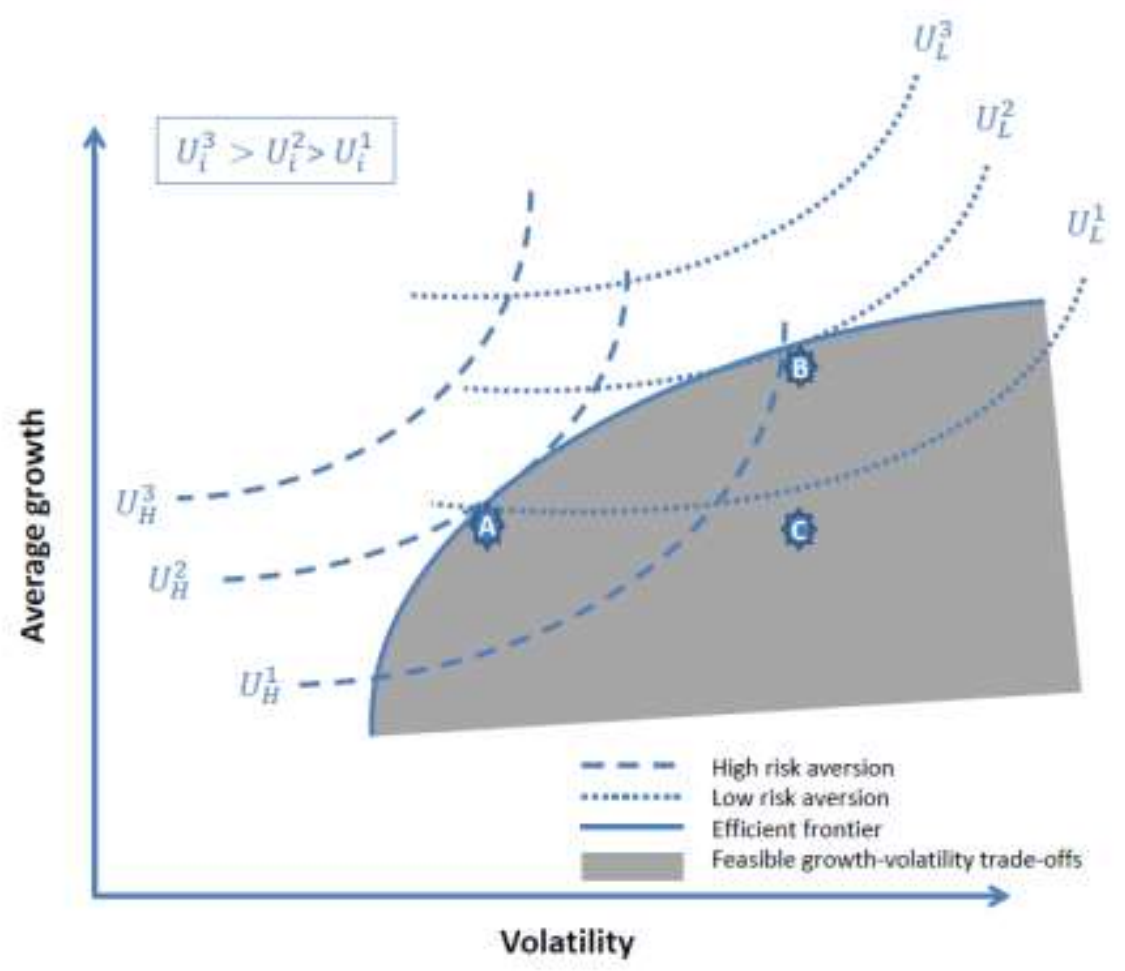

The highest attainable level of consumption utility depends on the set of feasible consumption profiles characterised by average growth and volatility pairs. All consumption profiles on the efficient frontier are optimal in the sense that none of these profiles is simultaneously dominated in terms of both average growth and volatility by any other profile within the feasible set. The greater the level of risk aversion, the greater is the slope of the frontier at the optimal growth-volatility trade-off and hence, the lower are both growth and volatility. Country $A$ is optimally located for highly risk-averse consumers while country B would be located sub-optimally since it leads to a lower level of consumption utility. For consumers with a low level of risk aversion country A would lead to lower utility than in country B. Finally, country $C$ is dominated by both country $A$ and $B$ in terms of the growth-volatility trade-off and this, independent of the level of risk aversion of its households. Indeed, households in country $\mathrm{C}$ would prefer to be in the position of households in country $\mathrm{A}$ who benefit from the same level of growth with lower volatility and similarly, they would prefer to live in country B since for the same level of volatility they would enjoy higher growth. The specific point on the frontier that a society would seek depends on the level of risk aversion.

95. Similar to Section 5, the panel of country-year observations can be used to assess the link between economic policies and the distance to the efficient frontier. The main, albeit tentative, result from this approach is that growth-enhancing reforms appear to reduce the distance to the growth-volatility frontier (Table 3). More flexible employment protection, lower unemployment-benefit replacement rates and more centralisation in wage bargaining are all associated with higher growth for a given amount of microeconomic volatility. This approach finds no statistically significant effect for product market regulation. 
Table 3. Distance to growth-volatility frontier and structural policies

Employment protection
Spending on ALMPs
Gross unemployment benefit
replacement rates
Centralisation of wance to
Credit intermediation bargaining
Product market regulation

Note: All policy indicators are standardised and centred. Estimation uses a sample of 173 observations across 21 countries. Timefixed and country-fixed effects are included. The shapes indicate the estimated relationship between policy estimators (rows) and the distance to the frontier (columns). The drawings show the shape of the estimated link across observed parameter values. Empty cells signify that the estimated coefficients are not significant at $10 \%$ level (see Table C7 in Appendix C for detailed regression coefficients and significance levels). Stars reflect confidence levels for the linear and squared term: ${ }^{* *}$ stands for $99 \%$, ${ }^{* *}$ for $95 \%$ and ${ }^{*}$ for $90 \%$.If significance differs between the linear and squared terms, the lower level is shown. For employment protection and the credit intermediation ratio only the squared term is significant.

Source: OECD calculations using CNEF, ECHP and EU-SILC and OECD statistics.

96. Increasing expenditure on active labour market policies is estimated to improve welfare from low to moderately high levels. In contrast, at very high levels (above 1 standard deviation from the average) further increases appear to reduce welfare.

97. More credit intermediation associated with being further from the frontier. Too much credit therefore seems detrimental to welfare. This tentative result is related to and consistent with recent empirical findings that increases in credit from the high levels observed in OECD countries generally slow down growth (Cournède and Denk, 2015).

98. In other words, countries that implement pro-growth policies generally seem to make better use of their level of volatility, in the sense of having growth that is close to the maximum level observed among countries with similar levels of volatility. This finding does not however mean that pro-growth reforms necessarily always improve welfare. Reaching a conclusion about welfare requires information about the preference that each society places on growth relative to volatility, a question left for further research.

\subsection{Trade-offs and complementarities between equity and micro-level stability}

99. Different pro-growth policy reforms can have different effects on micro-level stability, as the present study documents, and also on income inequality, as documented by other OECD work (Hoeller et al., 2014; Cournède et al., 2014; OECD, 2015). Table 4 summarises the effect of pro-growth reforms on income equality and microeconomic stability. The focus of this table is on the long-run effects, consistent with the emphasis of most empirical studies and the long-term orientation of Going for Growth priorities (OECD, 2015). 
100. Some policy reforms can boost long-run GDP per capita, promote income equality and increase micro-level stability (Table 4). They include:

- Relaxing labour and product market regulations if those reforms result in fully or near fully deregulated settings. As discussed previously, if the reforms do not go deep enough, countries starting from a very restrictive stance could fall in a reform trap and face a trade-off between boosting growth and enhancing equality but reducing micro-level stability. Reducing employment protection (EPL) for regular workers benefits income equality because it reduces labour market duality (assuming that EPL for temporary contracts is unchanged). Increasing product market competition tends to increase income equality because the positive effect of the reform on employment more than offsets its impact in terms of greater wage dispersion.

- $\quad$ Spending more on active labour market policies (ALMP): such an increase tends to boost the employment of less-skilled workers, while having little impact on earnings dispersion, which increases income equality. At the same time, higher ALMPs tend to increase micro-level stability by decreasing worker reallocation (Section 4.1).

Table 4. Equality and stability trade-offs of pro-growth reforms

\begin{tabular}{lcc}
\hline A pro-growth change: & \multicolumn{2}{c}{ Effect of change on: } \\
\hline Easing EPL for regular workers & $\begin{array}{c}\text { Income } \\
\text { equality }\end{array}$ & $\begin{array}{c}\text { Micro-level } \\
\text { stability }\end{array}$ \\
$\begin{array}{l}\text { Increasing product market competition } \\
\begin{array}{l}\text { Lowering unemployment insurance } \\
\text { replacement rate }\end{array}\end{array}$ & $+{ }^{1}$ & - \\
$\begin{array}{l}\text { Boosting ALMP spending } \\
\text { Reducing the total tax-GDP ratio }\end{array}$ & + & + \\
Reducing the size of social transfers & - & - \\
Reducing PIT progressivity & - & - \\
\hline
\end{tabular}

1. Earlier results were mixed, but recent evidence points to an overall reduction in inequality (OECD, 2015).

2. Overall inequality diminishes owing to employment effects. However, cutting benefits going to groups with low employment prospects can increase inequality.

Source: Hoeller et al. (eds.) (2014), Income Inequality in OECD Countries: What Are the Drivers and Policy Options?, World Scientific Publishing.; OECD (2015); Cournède et al. (2014), "Reconciling Fiscal Consolidation with Growth and Equity," OECD EConomic Studies, Vol. 2013. Issue 1.

101. In contrast, growth-enhancing reforms relating to the size of government tend to raise trade-offs with both equality and stability of income. Measures to reduce the tax burden or the size of transfers can boost growth by improving incentives, but they are also likely to result in greater income inequality while the present study indicates negative effects on micro-level stability. The same trade-off holds for reforms to reduce the progressivity of personal income taxation.

102. Growth-enhancing reforms of unemployment insurance schemes appear to fall in-between, as they can be compatible with greater income equality but can also be expected to increase instability. Progrowth reforms in this area generally increase equity by boosting labour force participation to an extent that more than offsets their effect of increasing wage dispersion. Micro-level disposable income stability however decreases by reducing an important buffer of household disposable income. This holds despite the finding that labour earnings volatility tends to decrease (see Section 4.1). 
103. Taxes and transfers are key policy levers to influence distributional outcomes and micro-level stability. While taxes are the most important instrument to achieve stability, transfers play a more limited role. Instead, cash transfers reduce income dispersion more than taxes (Hoeller et al., 2014). This raises a trade-off for a reform of the tax-benefit system, even though there are some complementarities that allow achieving both objectives, such as higher ALMPs and lower consumption taxes.

\section{Concluding remarks}

104. Recent OECD work has investigated the impact of policies on macroeconomic stability, but from a welfare perspective, it is economic stability at the household level that matters. While microeconomic instability can reflect growth-generating processes of creative destruction or more labour market dynamics boosting productivity growth, greater household-level instability translates into risk and for risk-averse individuals more instability reduces welfare for a given rate of growth. This study documents how progrowth reforms influence household-level economic stability.

105. This paper finds evidence suggesting that countries which tightly regulate employment or severely restrict competition can find themselves in "marginal-reform traps" where marginal reforms from very to moderately tight settings boost growth but entail greater economic instability for households. However, reforms that relax restrictions to highly deregulated settings are likely to reduce volatility. Deep reforms along one dimension, such as facilitating worker dismissal, require significant adjustment in other institutions, such active labour-market programmes, to help those that are negatively affected.

106. Household income after taxes and transfers does not vary as much as individual labour earnings when these experience large changes. The main sources of this attenuation vary across countries. Earnings from other family members is the most important smoothing instrument in southern European countries, while taxes and transfers are as important as income from other family members in reducing the impact of large changes in the labour earnings of the household head in the Nordic countries.

107. Finally, an exploratory methodology developed for the study suggests that growth-enhancing reforms generally seem to bring countries closer to the maximum level of growth that has been observed across countries for a given level of instability, the called "growth-volatility frontier". Taken at face value, this tentative finding would indicate that growth-enhancing reforms boost growth while improving its trade-off with micro-level stability even when they result in greater micro-level volatility. This raises a question as to whether pro-growth reforms generally boost economic welfare. Answering this question requires comparing societies' appetite for growth against their distaste for instability, an issue that is left for future research. 
ECO/WKP(2015)19

APPENDIX A. HOUSEHOLD PANELS

\section{A.1 Availability of household surveys}

Figure A1. Coverage of micro-panels by survey and country

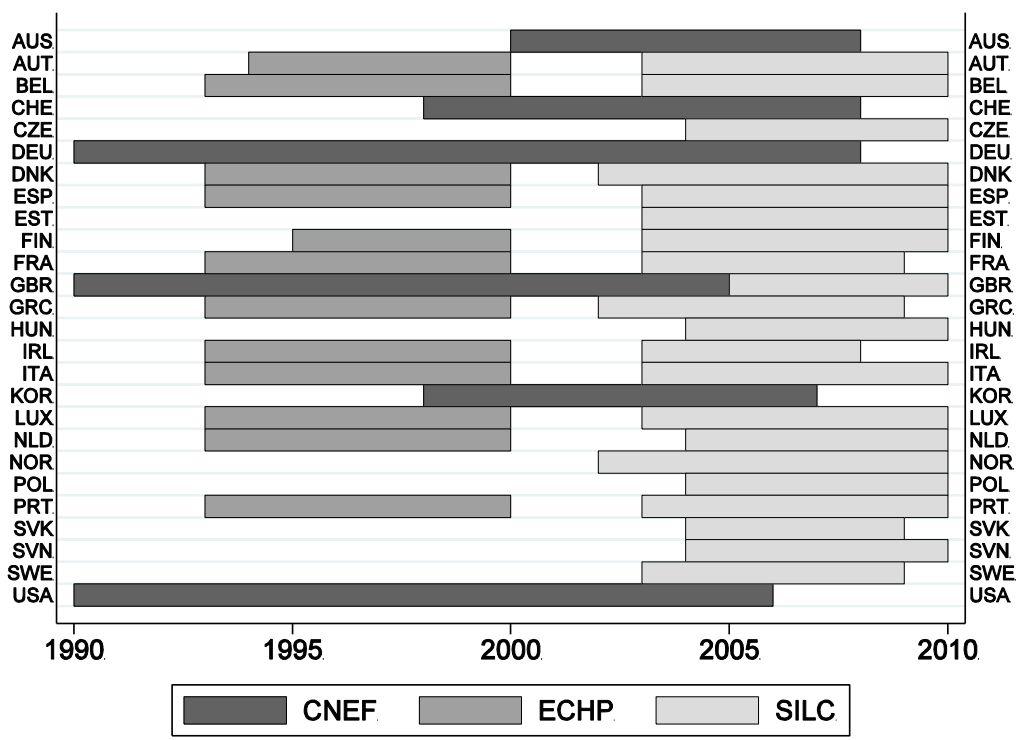

Note: Based on the availability of household disposable income data according to CNEF, ECHP and EU-SILC. Note that since 1996 USA survey is bi-annual. 
Figure A2. Number of observations by survey length per household

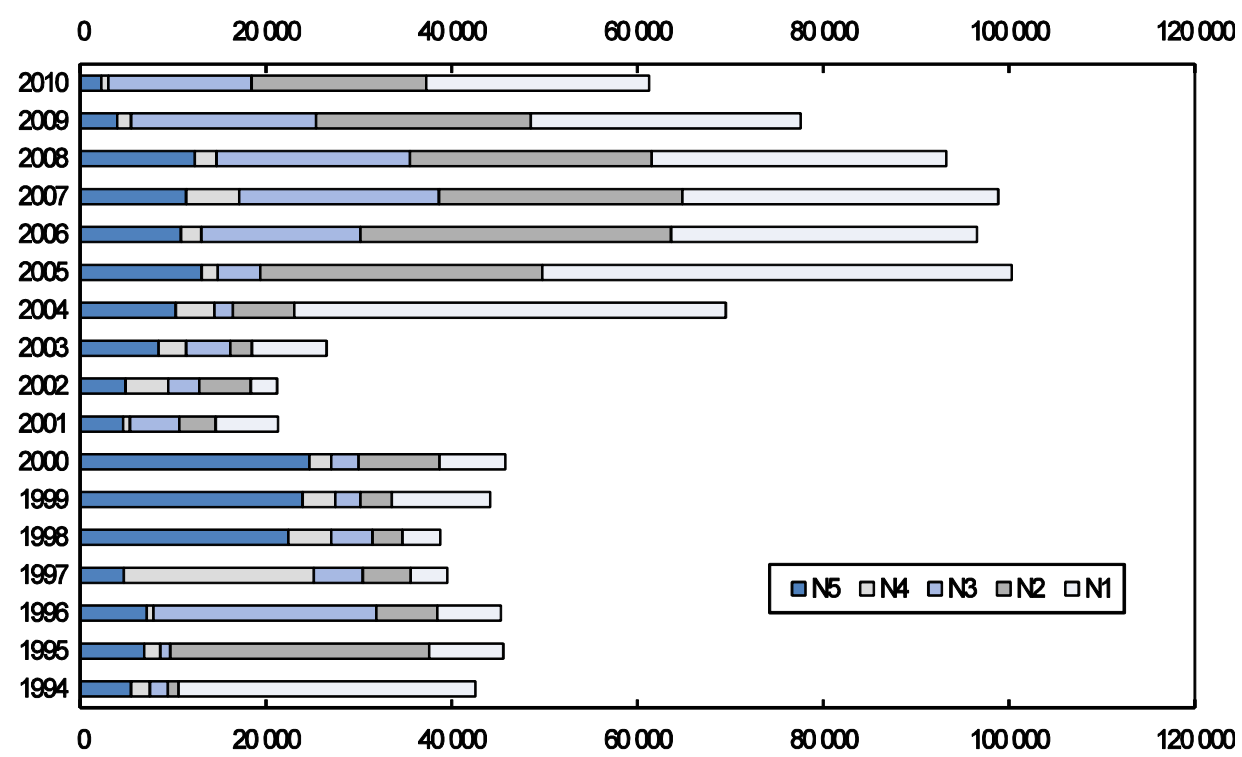

Note: Nx refers to the number of observations with at least $\mathrm{x}$ consecutive growth rates of household disposable income for the specific year.

\section{A.2 Disposable income volatility measurement issues}

108. Household measures (mainly disposable income) relate only to households with a head aged between 25 and 59 years old, excluding students as well as disabled and retired people. Only households with constant household size are considered. US academic studies that do not apply this restriction obtain higher measures of volatility than the present report. For instance, Zeliak et al. (2010) evaluate the volatility of after-tax household income at 50\% against $43 \%$ in the present study (in the United States in 2005). Pooling together the household-level data for all OECD countries, the distribution of household disposable income growth exhibits a cross-sectional standard deviation of 38\% across OECD countries in the period 2005-10 (Figure A3). 
Figure A3. Distribution of household disposable income growth

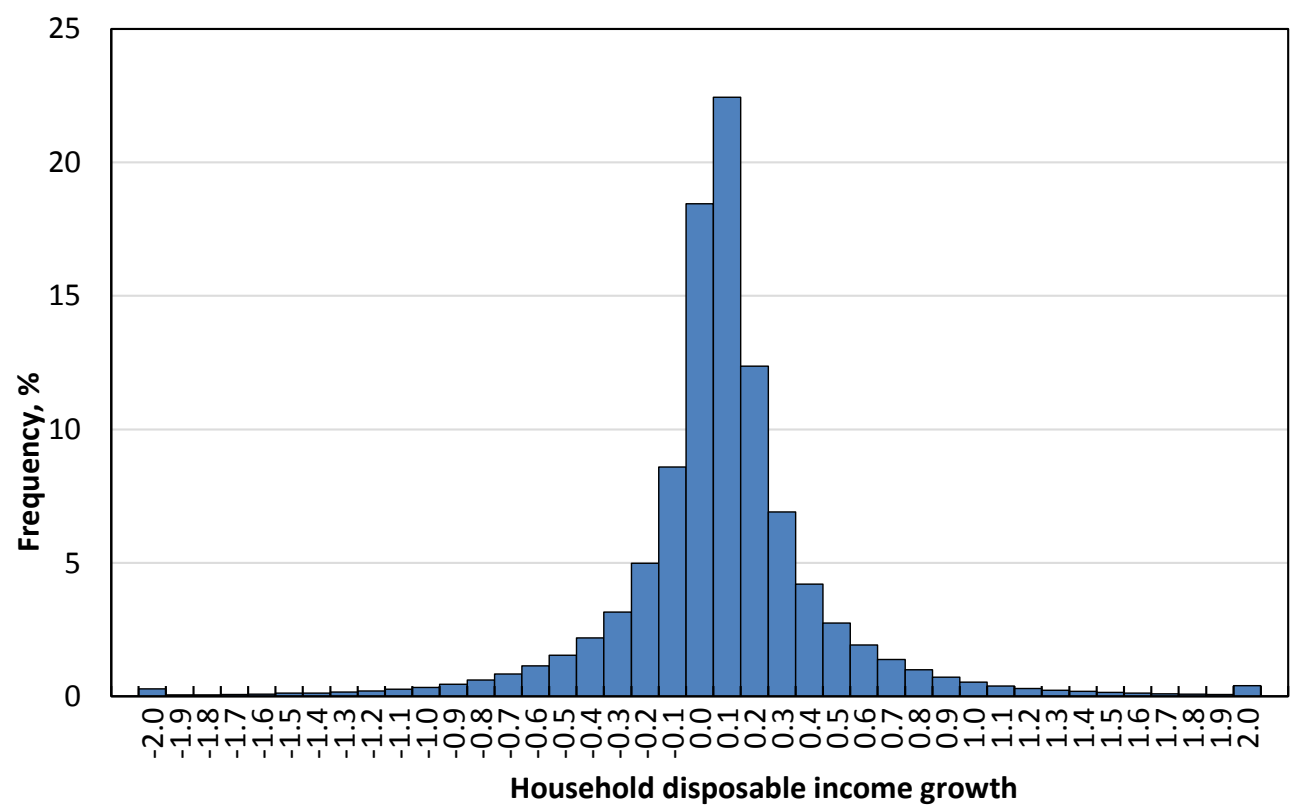

Note: Pooled household-level data for the period 2005-10.

Source: Calculations based on household panels (CNEF and EU-SILC).

109. A measure of household disposable income volatility excluding very large changes, for example, above 1.5 or below -1.5 is highly correlated with the main measure, which retains the very large changes (Figure A4). Excluding very large changes would reduce the average cross-sectional standard deviation to $33 \%$. However, from a welfare perspective, there is little basis for excluding very large changes in household disposable income when estimating its household-level volatility. More than $60 \%$ of the very large changes in household disposable income are due to swings in household head labour earnings, mainly because of employment-unemployment transitions. Hence, these very large changes are not considered as outliers but reflect episodes of income volatility that are particularly relevant for welfare. Consequently, the volatility measures used in the study retain very large changes (with one exception relating to hourly earnings, see below).

Figure A4. Household disposable income volatility excluding very large changes is highly correlated with the measure that keeps these observations

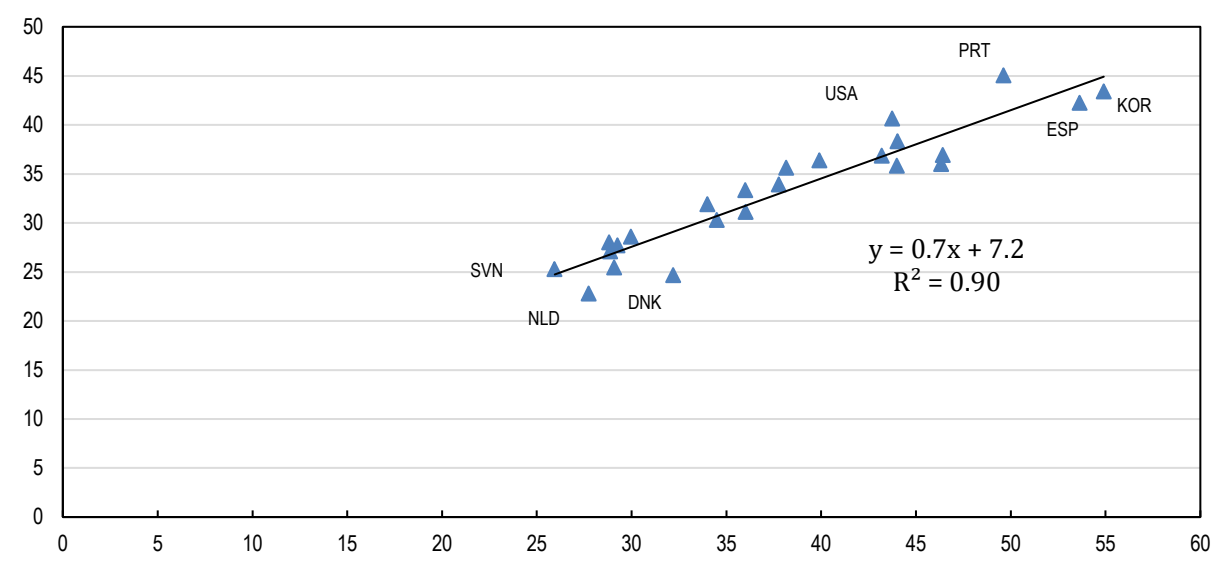

Source: Calculations based on household panels (CNEF and EU-SILC). 


\section{APPENDIX B. POLICY INDICATORS}

Table B1. Policy indicators

\begin{tabular}{|c|c|c|c|c|c|c|}
\hline & $\begin{array}{c}\text { EPL } \\
\text { Employment } \\
\text { Protection } \\
\text { Legislation for } \\
\text { regular workers }\end{array}$ & $\begin{array}{c}\text { PMR } \\
\text { Product } \\
\text { Market } \\
\text { Regulation }\end{array}$ & $\begin{array}{c}\text { GRR } \\
\text { Gross } \\
\text { Replacement } \\
\text { Rates }\end{array}$ & $\begin{array}{c}\text { CENT } \\
\text { Centralisation of } \\
\text { wage bargaining }\end{array}$ & $\begin{array}{c}\text { CIR } \\
\text { Credit } \\
\text { Intermediation } \\
\text { Ratio }\end{array}$ & $\begin{array}{c}\text { ALMP } \\
\text { Spending on } \\
\text { Active } \\
\text { Labour Market } \\
\text { Policies (\% GDP) }\end{array}$ \\
\hline AUS & $1.2(1.4)$ & $1.4(1.7)$ & $28.0(-)$ & $0.4(0.5)$ & $0.5(0.4)$ & $0.2(0.2)$ \\
\hline AUT & $2.4(2.8)$ & $1.4(2.1)$ & $32.0(32.5)$ & $0.9(1.0)$ & $0.4(0.5)$ & $0.6(0.3)$ \\
\hline BEL & $1.8(1.8)$ & $1.6(2.2)$ & $41.0(39.5)$ & $0.5(0.5)$ & $0.3(0.2)$ & $1.1(1.0)$ \\
\hline CAN & $0.9(0.9)$ & $1.5(1.9)$ & $13.5(15.0)$ & $0.3(0.3)$ & $0.4(0.3)$ & $0.2(0.3)$ \\
\hline $\mathrm{CHE}$ & $1.6(1.6)$ & $1.5(2.5)$ & $32.0(35.5)$ & $0.3(0.3)$ & $0.6(-)$ & $0.5(0.6)$ \\
\hline CZE & $3.1(3.3)$ & $1.5(2.6)$ & $6.0(-)$ & $0.2(0.3)$ & $0.2(0.2)$ & $0.1(0.1)$ \\
\hline DEU & $2.9(2.7)$ & $1.3(2.2)$ & $20.5(26.5)$ & $0.5(0.5)$ & $0.5(0.5)$ & $0.5(1.0)$ \\
\hline DNK & $2.1(2.1)$ & $1.3(1.7)$ & $53.0(62.5)$ & $0.4(0.5)$ & $0.6(0.4)$ & $1.2(1.6)$ \\
\hline ESP & $2.4(2.4)$ & $1.6(2.4)$ & $35.0(35.0)$ & $0.4(0.3)$ & $0.4(0.3)$ & $0.7(0.5)$ \\
\hline EST & $2.7(-)$ & $1.4(-)$ & $-(-)$ & $-(-)$ & $0.4(0.2)$ & $0.1(-)$ \\
\hline FIN & $2.2(2.3)$ & $1.3(1.9)$ & $33.0(34.0)$ & $0.4(0.4)$ & $0.3(0.2)$ & $0.7(1.0)$ \\
\hline FRA & $2.5(2.3)$ & $1.5(2.3)$ & $39.0(37.0)$ & $0.2(0.2)$ & $0.3(0.2)$ & $0.7(1.0)$ \\
\hline GBR & $1.2(1.0)$ & $1.2(1.3)$ & $15.5(17.5)$ & $0.1(0.1)$ & $0.7(0.4)$ & $0.0(0.1)$ \\
\hline GRC & $2.8(2.8)$ & $2.2(2.7)$ & $14.0(16.5)$ & $0.3(0.3)$ & $0.4(0.2)$ & $0.2(0.2)$ \\
\hline HUN & $2.0(2.0)$ & $1.4(2.6)$ & $13.5(-)$ & $0.2(0.2)$ & $0.2(0.2)$ & $0.3(0.3)$ \\
\hline $\mathrm{IRL}$ & $1.3(1.4)$ & $1.4(1.9)$ & $40.5(29.0)$ & $0.5(0.5)$ & $1.1(-)$ & $0.6(0.9)$ \\
\hline ITA & $2.8(2.8)$ & $1.5(2.3)$ & $36.0(26.0)$ & $0.3(0.4)$ & $0.3(0.2)$ & $0.4(0.5)$ \\
\hline KOR & $2.4(2.4)$ & $1.9(2.5)$ & $9.0(-)$ & $-(-)$ & $0.4(-)$ & $0.3(-)$ \\
\hline LUX & $2.2(-)$ & $-(-)$ & $27.0(-)$ & $0.3(0.3)$ & $1.5(-)$ & $0.4(0.2)$ \\
\hline NLD & $2.9(2.8)$ & $1.0(1.8)$ & $35.0(52.0)$ & $0.6(0.6)$ & $1.0(0.6)$ & $0.8(1.0)$ \\
\hline NOR & $2.3(2.3)$ & $1.5(1.9)$ & $47.0(40.0)$ & $0.5(0.5)$ & $0.4(0.4)$ & $0.5(0.7)$ \\
\hline POL & $2.2(2.2)$ & $-(-)$ & $10.5(-)$ & $0.3(0.2)$ & $0.2(0.1)$ & $0.5(0.4)$ \\
\hline PRT & $4.4(4.6)$ & $1.7(2.6)$ & $45.0(40.0)$ & $0.3(0.3)$ & $0.3(0.2)$ & $0.5(0.4)$ \\
\hline SVK & $2.2(2.5)$ & $1.6(-)$ & $-(-)$ & $0.5(0.5)$ & $0.2(0.1)$ & $0.2(0.3)$ \\
\hline SVN & $2.7(-)$ & $2.0(-)$ & $-(-)$ & $0.5(0.4)$ & $0.4(-)$ & $0.2(-)$ \\
\hline SWE & $2.6(2.7)$ & $1.6(1.9)$ & $37.5(25.5)$ & $0.5(0.5)$ & $0.3(0.2)$ & $0.8(1.9)$ \\
\hline USA & $0.3(0.3)$ & $1.1(1.5)$ & $19.0(14.0)$ & $0.2(0.2)$ & $0.4(0.3)$ & $0.1(0.1)$ \\
\hline
\end{tabular}

Note: Policy indicators are shown in 2008 (1998 between brackets). EPL is the OECD indicator of strictness of employment protection for regular contracts (ranging from 0 to 6 from weakest to strongest). The present study uses Version 1 of this indicator. PMR stands for the OECD Indicator of Product Market Regulation (ranging from 0 to 6). GRR is the gross replacement rate which compares unemployment benefits with earlier wages; it is taken from the OECD Benefits and Wages database. CENT is an index of centralisation in wage bargaining; it ranges from 0 to 1 and comes from the ICTWSS database. The credit intermediation ratio, CIR, denotes the share of loans (by banks and other financial intermediaries) in the total liabilities of other sectors of the economy, including non-financial corporations, the general government (S13), and households and NPISHs from Annual National Accounts, Table 720 - Financial Balance Sheets. ALMP stands for government spending on active labour market programmes (10-70) as percentage of GDP, smoothed using a Hodrick Prescott filter of 6.25 .

Source: OECD databases and ICTWSS. 


\section{APPENDIX C. PANEL REGRESSION RESULTS}

Table C1. Labour reallocation and policies

\begin{tabular}{|c|c|c|c|c|c|}
\hline & & \multicolumn{4}{|c|}{ Annual hours worked } \\
\hline & $\begin{array}{l}\text { Worker } \\
\text { reallocation }\end{array}$ & $\begin{array}{c}20 \% \\
\text { changes }\end{array}$ & $\begin{array}{l}\text { Large } \\
\text { declines }\end{array}$ & $\begin{array}{l}\text { Cross } \\
\text { sectional }\end{array}$ & $\begin{array}{l}3 \text { year } \\
\text { rolling } \\
\text { window }\end{array}$ \\
\hline \multirow[t]{2}{*}{ Employment protection - EPL } & $5.929^{*}$ & $0.583^{* * *}$ & $0.266^{* * *}$ & $0.697^{* \star *}$ & $0.553^{*}$ \\
\hline & (3.182) & $(0.117)$ & $(0.0665)$ & $(0.140)$ & $(0.305)$ \\
\hline \multirow[t]{2}{*}{$S q-E P L$} & $-1.285^{*}$ & $-0.0965^{\star * *}$ & $-0.0431^{\star * *}$ & $-0.132^{* * *}$ & $-0.131^{* *}$ \\
\hline & $(0.618)$ & $(0.0192)$ & $(0.0110)$ & $(0.0283)$ & $(0.0489)$ \\
\hline \multirow[t]{2}{*}{ Active labour market programmes - ALMP } & $-2.922^{* *}$ & 0.0425 & 0.0213 & -0.0275 & -0.119 \\
\hline & $(1.098)$ & $(0.0467)$ & $(0.0196)$ & $(0.0532)$ & $(0.112)$ \\
\hline \multirow[t]{2}{*}{ Gross replacement rates - GRR } & 0.00531 & $0.00388^{* *}$ & $0.00169^{*}$ & 0.00355 & -0.00765 \\
\hline & $(0.0476)$ & $(0.00171)$ & $(0.000850)$ & $(0.00218)$ & $(0.00652)$ \\
\hline \multirow[t]{2}{*}{ Centralisation of wage bargaining - Cent } & -5.307 & $1.709^{* * *}$ & $1.006^{* * *}$ & $1.899^{* * *}$ & 2.461 \\
\hline & $(8.708)$ & $(0.396)$ & $(0.220)$ & $(0.426)$ & $(1.512)$ \\
\hline \multirow[t]{2}{*}{ Sq Cent } & & $-1.414^{* * *}$ & $-0.922^{* * *}$ & $-1.340^{* * *}$ & -1.241 \\
\hline & & $(0.262)$ & $(0.138)$ & $(0.248)$ & $(1.310)$ \\
\hline \multirow[t]{2}{*}{ Credit intermediation ratio - CIR } & $-30.62^{\star \star \star}$ & $-1.000^{\star * *}$ & $-0.400^{\star \star *}$ & $-0.932^{\star \star *}$ & $-1.599^{* * *}$ \\
\hline & $(4.756)$ & $(0.190)$ & $(0.0984)$ & $(0.159)$ & $(0.285)$ \\
\hline \multirow[t]{2}{*}{$\mathrm{Sq} \mathrm{CIR}$} & $16.73^{* * *}$ & $0.560^{* * *}$ & $0.221^{* * *}$ & $0.526^{* * *}$ & $1.115^{\star * *}$ \\
\hline & $(2.163)$ & $(0.110)$ & $(0.0583)$ & $(0.0877)$ & $(0.259)$ \\
\hline \multirow[t]{2}{*}{ Product Market Regulation - PMR } & -4.574 & $0.458^{* * *}$ & $0.204^{* *}$ & $0.594^{* * *}$ & $1.169^{\star}$ \\
\hline & (7.599) & $(0.131)$ & $(0.0799)$ & $(0.137)$ & $(0.584)$ \\
\hline \multirow[t]{2}{*}{$S q-P M R$} & 2.130 & $-0.108^{\star * *}$ & $-0.0475^{\star \star}$ & $-0.131^{* * *}$ & $-0.285^{*}$ \\
\hline & $(1.877)$ & $(0.0310)$ & $(0.0211)$ & $(0.0326)$ & $(0.152)$ \\
\hline \multirow[t]{2}{*}{ Output gap } & 0.0827 & 0.000768 & -0.00115 & -0.000419 & -0.00115 \\
\hline & $(0.0721)$ & $(0.00148)$ & $(0.00110)$ & $(0.00229)$ & $(0.00743)$ \\
\hline \multirow[t]{2}{*}{ Constant } & $24.00^{\star *}$ & $-1.232^{\star \star \star}$ & $-0.619^{\star * *}$ & $-1.445^{\star \star *}$ & $-1.475^{\star * *}$ \\
\hline & (9.725) & $(0.265)$ & $(0.128)$ & $(0.292)$ & $(0.421)$ \\
\hline Observations & 144 & 154 & 154 & 154 & 40 \\
\hline Number of countries & 18 & 20 & 20 & 20 & 19 \\
\hline Adjusted R-squared & 0.556 & 0.451 & 0.351 & 0.306 & 0.705 \\
\hline
\end{tabular}

Notes: Standard OLS regressions including country and time-fixed effects. Robust standard errors are adjusted by clustering at the country level. ${ }^{* * *} p<0.01,{ }^{* *} p<0.05,{ }^{*} p<0.1$. The data span from 1994 to 2010 . See table C5.

Source: Based on CNEF, ECHP and EU-SILC. 
ECO/WKP(2015)19

Table C2. Hourly earnings volatility and policies

\begin{tabular}{|c|c|c|c|c|}
\hline Hourly earnings & $\begin{array}{c}20 \% \\
\text { changes }\end{array}$ & $\begin{array}{l}\text { Large } \\
\text { declines }\end{array}$ & $\begin{array}{l}\text { Cross } \\
\text { sectional }\end{array}$ & $\begin{array}{l}3 \text { year } \\
\text { rolling } \\
\text { window }\end{array}$ \\
\hline \multirow[t]{2}{*}{ EPL } & $0.384^{\star *}$ & $0.291^{\star * *}$ & $0.162^{*}$ & $0.772^{* * *}$ \\
\hline & $(0.160)$ & $(0.0828)$ & $(0.0779)$ & $(0.232)$ \\
\hline \multirow[t]{2}{*}{ EPL^2 } & $-0.0762^{\star *}$ & $-0.0580^{\star \star *}$ & $-0.0341^{* *}$ & $-0.142^{\star \star \star}$ \\
\hline & $(0.0357)$ & $(0.0183)$ & $(0.0154)$ & $(0.0365)$ \\
\hline \multirow[t]{2}{*}{ ALMP } & -0.00485 & -0.0185 & -0.0496 & -0.0472 \\
\hline & $(0.0514)$ & $(0.0376)$ & $(0.0338)$ & $(0.0519)$ \\
\hline \multirow[t]{2}{*}{ GRR } & $0.00981^{\star *}$ & $0.00538^{\star \star}$ & $0.00584^{\star *}$ & -0.00233 \\
\hline & $(0.00367)$ & $(0.00236)$ & $(0.00216)$ & $(0.00275)$ \\
\hline \multirow[t]{2}{*}{ Cent } & $2.406^{\star \star \star}$ & $1.919^{\star \star *}$ & $1.058^{\star \star *}$ & $3.183^{\star \star *}$ \\
\hline & $(0.589)$ & $(0.586)$ & $(0.203)$ & $(0.963)$ \\
\hline \multirow[t]{2}{*}{ Cent $^{\wedge} 2$} & $-2.335^{\star \star \star}$ & $-1.699^{\star \star *}$ & $-1.012^{\star \star \star}$ & $-2.992^{\star \star \star}$ \\
\hline & $(0.429)$ & $(0.497)$ & $(0.162)$ & (1.027) \\
\hline \multirow[t]{2}{*}{ CIR } & $-0.941^{* * *}$ & -0.285 & $-0.469^{* * *}$ & 0.0545 \\
\hline & $(0.250)$ & $(0.238)$ & $(0.121)$ & $(0.246)$ \\
\hline \multirow[t]{2}{*}{$\mathrm{CIR}^{\wedge} 2$} & $0.504^{* * *}$ & 0.248 & $0.244^{\star \star *}$ & -0.156 \\
\hline & $(0.174)$ & $(0.180)$ & $(0.0601)$ & $(0.201)$ \\
\hline \multirow[t]{2}{*}{ PMR } & $0.105^{\star *}$ & 0.0504 & 0.0398 & -0.0248 \\
\hline & $(0.0463)$ & $(0.0401)$ & $(0.0269)$ & $(0.0552)$ \\
\hline \multirow[t]{2}{*}{ Output gap } & 0.00336 & 0.000536 & 0.000541 & 0.00569 \\
\hline & $(0.00338)$ & $(0.00293)$ & $(0.00147)$ & $(0.00339)$ \\
\hline \multirow[t]{2}{*}{ Constant } & $-0.854^{* *}$ & $-0.804^{\star * *}$ & -0.223 & $-1.135^{\star * *}$ \\
\hline & $(0.318)$ & $(0.277)$ & $(0.168)$ & $(0.327)$ \\
\hline Observations & 154 & 154 & 154 & 40 \\
\hline $\begin{array}{l}\text { Number of } \\
\text { countries }\end{array}$ & 20 & 20 & 20 & 20 \\
\hline Adjusted R2 & 0.260 & 0.176 & 0.279 & 0.610 \\
\hline
\end{tabular}

Note: Standard OLS regressions including country and time-fixed effects. Robust standard errors are adjusted by clustering at the country level. ${ }^{* * *} p<0.01,{ }^{* *} p<0.05,{ }^{*} p<0.1$. The data span from 1994 to 2010. See Table C5.

Source: Based on CNEF, ECHP and EU-SILC. 
Table C3. Annual hours worked, policies and individual characteristics

\begin{tabular}{|c|c|c|c|c|c|c|c|}
\hline & & \multicolumn{3}{|c|}{ Large changes } & \multicolumn{3}{|c|}{ Rolling window } \\
\hline \multicolumn{2}{|l|}{ EPL } & $2.282^{* * *}$ & $2.283^{\star \star \star}$ & $2.609^{* * *}$ & $1.383^{* * *}$ & $1.416^{\star \star \star}$ & $1.425^{\star \star \star}$ \\
\hline \multirow[t]{3}{*}{ EPL^2 } & & $-0.411^{* * *}$ & $-0.415^{\star * \star}$ & $-0.494^{* * *}$ & $-0.258^{\star * *}$ & $-0.266^{\star * *}$ & $-0.264^{* * *}$ \\
\hline & High school & -0.0113 & & & -0.00499 & & \\
\hline & More than high school & $0.0392^{* * *}$ & & & $0.0104^{*}$ & & \\
\hline \multirow{4}{*}{$\begin{array}{l}\text { Interaction } \\
\text { with }\end{array}$} & Age & & $5.56 \mathrm{E}-04$ & & & $3.94 \mathrm{e}-04^{*}$ & \\
\hline & 2nd quartile & & & $0.0735^{\star}$ & & & -0.0317 \\
\hline & 3rd quartile & & & $0.0605^{*}$ & & & -0.0228 \\
\hline & 4th quartile & & & $0.0730^{* *}$ & & & -0.0173 \\
\hline \multirow[t]{3}{*}{ ALMP } & & 0.114 & $0.468^{\star * *}$ & $0.534^{* * *}$ & 0.00886 & $0.0744^{\star *}$ & 0.0447 \\
\hline & High school & $0.0945^{* * *}$ & & & $0.0228^{\star *}$ & & \\
\hline & More than high school & 0.0509 & & & 0.0110 & & \\
\hline \multirow{4}{*}{$\begin{array}{l}\text { Interaction } \\
\text { with }\end{array}$} & Age & & $-0.00723^{\star \star *}$ & & & $-0.00117^{* \star *}$ & \\
\hline & 2nd quartile & & & $-0.438^{* \star *}$ & & 4. $19 e-05^{\star \star *}$ & \\
\hline & 3rd quartile & & & $-0.425^{\star \star \star}$ & & & $-0.0756^{*}$ \\
\hline & 4th quartile & & & $-0.400^{\star * *}$ & & & -0.0528 \\
\hline \multirow[t]{3}{*}{ GRR } & & 0.00337 & -0.00411 & -0.00923 & & & -0.0491 \\
\hline & High school & $-0.00173^{*}$ & & & -0.000881 & $-0.00306^{*}$ & $-0.00386^{*}$ \\
\hline & More than high school & -0.000219 & & & $-0.000808^{* * *}$ & & \\
\hline \multirow{4}{*}{$\begin{array}{c}\text { Interaction } \\
\text { with }\end{array}$} & Age & & $0.00016^{* * *}$ & & -0.000238 & & \\
\hline & 2nd quartile & & & 0.00575 & & & 0.000375 \\
\hline & 3rd quartile & & & $0.00858^{* * *}$ & & & 0.00120 \\
\hline & 4th quartile & & & $0.00958^{\star \star *}$ & & & $0.00191^{*}$ \\
\hline \multicolumn{2}{|l|}{ Cent } & $6.074^{* * *}$ & $6.190^{* * *}$ & $5.855^{\star \star \star}$ & $2.510^{* * *}$ & $2.806^{\star * *}$ & $2.624^{\star \star \star}$ \\
\hline \multicolumn{2}{|l|}{ Cent^2 } & $-4.303^{\star \star \star}$ & $-4.278^{\star \star \star}$ & $-4.160^{* *}$ & $-1.427^{* *}$ & $-1.544^{\star \star \star}$ & $-1.591^{\star * *}$ \\
\hline \multirow{6}{*}{$\begin{array}{c}\text { Interaction } \\
\text { with }\end{array}$} & High school & 0.0247 & & & 0.0104 & & \\
\hline & More than high school & 0.103 & & & 0.00273 & & \\
\hline & Age & & -0.00248 & & & $-0.00342^{* * *}$ & \\
\hline & 2nd quartile & & & $0.638^{* * *}$ & & & 0.0380 \\
\hline & 3rd quartile & & & $0.430^{\star * *}$ & & & -0.0145 \\
\hline & 4th quartile & & & $0.431^{* *}$ & & & -0.00557 \\
\hline \multicolumn{2}{|l|}{ CIR } & $-3.936^{\star * *}$ & $-4.190^{\star \star *}$ & $-4.028^{\star \star *}$ & $-1.222^{\star \star *}$ & $-1.340^{\star * *}$ & $-1.230^{\star * *}$ \\
\hline \multicolumn{2}{|l|}{$\mathrm{CIR}^{\wedge} 2$} & $2.386^{\star * *}$ & $2.389^{* * *}$ & $2.554^{\star * *}$ & $0.858^{* * *}$ & $0.842^{* * *}$ & $0.869^{* * *}$ \\
\hline \multirow{6}{*}{$\begin{array}{l}\text { Interaction } \\
\text { with }\end{array}$} & High School & -0.0308 & & & -0.0141 & & \\
\hline & More than high school & 0.0157 & & & -0.0207 & & \\
\hline & Age & & $0.00590^{* * *}$ & & & $0.00217^{\star \star}$ & \\
\hline & 2nd quartile & & & -0.137 & & & -0.010 \\
\hline & 3rd quartile & & & -0.0577 & & & -0.0277 \\
\hline & 4th quartile & & & -0.207 & & & -0.0701 \\
\hline \multicolumn{2}{|l|}{ PMR } & $1.176^{\star \star}$ & $1.063^{\star *}$ & $1.282^{\star *}$ & $0.296^{*}$ & $0.216^{*}$ & $0.300^{*}$ \\
\hline \multicolumn{2}{|l|}{$\mathrm{PMR}^{\wedge} 2$} & $-0.286^{\star *}$ & $-0.285^{\star *}$ & $-0.301^{* *}$ & -0.0415 & -0.0248 & -0.0555 \\
\hline \multirow{6}{*}{$\begin{array}{l}\text { Interaction } \\
\text { with }\end{array}$} & High School & $0.0647^{*}$ & & & -0.00978 & & \\
\hline & More than high school & -0.00853 & & & -0.0114 & & \\
\hline & Age & & $0.00316^{\star * *}$ & & & 0.000343 & \\
\hline & 2nd quartile & & & 0.181 & & & 0.0653 \\
\hline & 3rd quartile & & & 0.0130 & & & 0.0171 \\
\hline & 4th quartile & & & $-3.19 e-05$ & & & 0.0126 \\
\hline
\end{tabular}


ECO/WKP(2015)19

Table C3. Annual hours worked, policies and individual characteristics (cont.)

\begin{tabular}{|c|c|c|c|c|c|c|}
\hline \multirow[b]{2}{*}{ Output gap } & \multicolumn{3}{|c|}{ Large changes } & \multicolumn{3}{|c|}{ Rolling window } \\
\hline & -0.000133 & 0.000387 & -0.00195 & $-0.00845^{\star \star \star}$ & $-0.00847^{* * *}$ & $-0.0067^{\star \star \star}$ \\
\hline Age & $-0.0303^{* * *}$ & $-0.0378^{* * *}$ & $-0.0303^{\star * *}$ & $-0.0106^{* * *}$ & $-0.0121^{* \star *}$ & $-0.0104^{* * *}$ \\
\hline $\mathrm{Age}^{\wedge} 2$ & $0.0002^{\star * *}$ & $0.0002^{* * *}$ & $0.0002^{* \star *}$ & $0.00001^{\star * *}$ & $0.00001^{\star \star *}$ & $0.00001^{* * *}$ \\
\hline Male & $0.145^{\star \star \star}$ & $0.145^{\star \star \star}$ & $0.147^{\star \star \star}$ & $0.0239^{\star \star *}$ & $0.0238^{\star \star \star}$ & $0.0242^{* \star *}$ \\
\hline High school & -0.0507 & $0.0431^{* \star *}$ & $0.0389^{* * *}$ & $0.0437^{\star *}$ & 0.00544 & 0.00405 \\
\hline More than high school & 0.0163 & $0.163^{\star * *}$ & $0.163^{\star \star \star}$ & 0.0334 & $0.0320^{* \star *}$ & $0.0303^{* * *}$ \\
\hline Full time & 0.00582 & 0.00563 & 0.0110 & $0.0245^{\star}$ & $0.0244^{*}$ & $0.0257^{\star}$ \\
\hline 2nd quartile & $0.445^{\star \star *}$ & $0.445^{\star \star \star}$ & -0.0636 & $0.0687^{* * *}$ & $0.0689^{* * *}$ & 0.0733 \\
\hline 3rd quartile & $0.0642^{\star *}$ & $0.0642^{* *}$ & -0.197 & -0.00425 & -0.00403 & 0.0427 \\
\hline 4th quartile & 0.0456 & 0.0463 & -0.216 & -0.00778 & -0.00753 & 0.0190 \\
\hline If couple & $-0.0324^{* *}$ & $-0.0368^{* * *}$ & $-0.0301^{* *}$ & -0.00544 & -0.00594 & -0.00513 \\
\hline Constant & $-3.994^{\star \star \star}$ & $-3.773^{\star \star \star}$ & $-4.232^{\star \star \star}$ & $-1.635^{\star \star \star}$ & $-1.593^{\star \star \star}$ & $-1.630^{\star * \star}$ \\
\hline Observations & 807,381 & 807,381 & 807,381 & 84,592 & 84,592 & 84,592 \\
\hline
\end{tabular}

Notes: Estimations using the incidence of $20 \%$ changes come from probit regressions, and using the rolling window standard OLS. All regressions include country and time-fixed effects. Robust standard errors are adjusted by clustering at the country-time level. Only the coefficients are shown in the table. ${ }^{* * *} p<0.01,{ }^{* *} p<0.05,{ }^{*} p<0.1$. The data span from 1994 to 2010 . See Table C5.

Source: Based on CNEF, ECHP and SILC. 
Table C4. Volatility of hourly earnings, policies and individual characteristics

\begin{tabular}{|c|c|c|c|c|c|c|c|}
\hline & & \multicolumn{3}{|c|}{ Large changes } & \multicolumn{3}{|c|}{ Rolling window } \\
\hline \multicolumn{2}{|l|}{ EPL } & 0.548 & 0.477 & $1.269^{\star \star \star}$ & $0.905^{\star \star}$ & $0.827^{\star *}$ & $0.974^{* * *}$ \\
\hline \multirow[t]{3}{*}{ EPL^2 } & & -0.0946 & -0.0967 & $-0.317^{* * *}$ & $-0.167^{\star * *}$ & $-0.158^{* * *}$ & $-0.181^{* * *}$ \\
\hline & High school & $0.0220^{*}$ & & & 0.00201 & & \\
\hline & More than high school & $0.0355^{\star *}$ & & & 0.0123 & & \\
\hline \multirow{4}{*}{$\begin{array}{l}\text { Interaction } \\
\text { with }\end{array}$} & Age & & $0.00199^{* \star *}$ & & & $0.000598^{\star * \star}$ & \\
\hline & 2nd quartile & & & $0.194^{* * *}$ & & & 0.00576 \\
\hline & 3rd quartile & & & $0.238^{\star \star \star}$ & & & 0.0269 \\
\hline & 4th quartile & & & $0.273^{* * *}$ & & & 0.0362 \\
\hline \multirow{6}{*}{$\begin{array}{l}\text { ALMP } \\
\text { Interaction } \\
\text { with }\end{array}$} & & $-0.205^{\star}$ & -0.00244 & $0.968^{\star \star \star}$ & -0.0598 & 0.0333 & $-0.230^{\star *}$ \\
\hline & High school & $0.0635^{\star *}$ & & & $0.0439^{* * *}$ & & \\
\hline & More than high school & -0.0300 & & & 0.0280 & & \\
\hline & Age & & $-0.00445^{\star * *}$ & & & $-0.00156^{\star *}$ & \\
\hline & 2nd quartile & & & $-1.085^{\star \star *}$ & & & 0.0994 \\
\hline & 3rd quartile & & & $-1.004^{\star \star *}$ & & & $0.207^{\star}$ \\
\hline \multicolumn{2}{|l|}{ GRR } & $0.0424^{* * *}$ & $0.0429^{\star \star \star}$ & -0.00101 & -0.00186 & -0.00380 & 0.00153 \\
\hline \multirow{6}{*}{$\begin{array}{l}\text { Interaction } \\
\text { with }\end{array}$} & High school & $-0.0033^{* * *}$ & & & -0.00108 & & \\
\hline & More than high school & -0.000425 & & & -0.000255 & & \\
\hline & Age & & $-4.33 e-05$ & & & $4.06 e-05$ & \\
\hline & 2nd quartile & & & $0.0282^{* * *}$ & & & -0.00275 \\
\hline & 3rd quartile & & & $0.0221^{* * *}$ & & & -0.00435 \\
\hline & 4th quartile & & & $0.0280^{* * *}$ & & & -0.00314 \\
\hline \multicolumn{2}{|l|}{ Cent } & $4.246^{* * *}$ & $3.997^{* *}$ & $5.708^{* * *}$ & $3.316^{*}$ & $3.147^{*}$ & $3.920^{* *}$ \\
\hline \multicolumn{2}{|l|}{ Cent^2 } & $-4.722^{\star \star}$ & $-4.694^{\star \star}$ & $-3.688^{*}$ & -3.072 & -2.868 & -3.223 \\
\hline \multirow{5}{*}{$\begin{array}{l}\text { Interaction } \\
\text { with }\end{array}$} & High school & 0.0464 & & & 0.0448 & & \\
\hline & More than high school & 0.104 & & & -0.00491 & & \\
\hline & Age & & $0.00528^{*}$ & & & -0.00111 & \\
\hline & 2nd quartile & & & $-1.333^{\star * *}$ & & & $-0.426^{*}$ \\
\hline & 3rd quartile & & & $-1.596^{\star * *}$ & & & $-0.668^{* * *}$ \\
\hline
\end{tabular}


ECO/WKP(2015)19

Table C4. Volatility of hourly earnings, policies and individual characteristics (cont.)

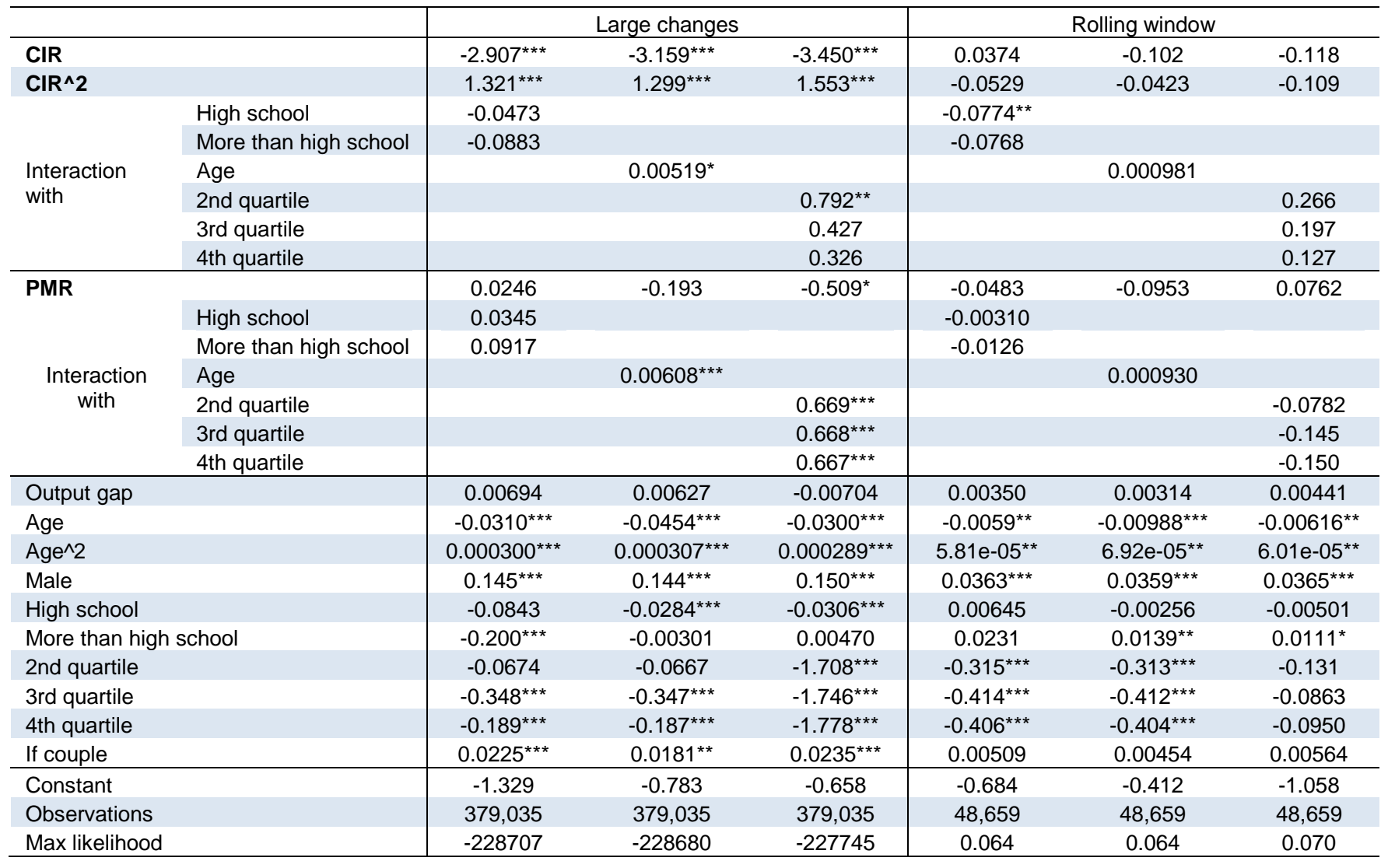

Notes: Estimations using the incidence of $20 \%$ changes come from probit regressions, and using the rolling window standard OLS. All regressions include country and time-fixed effects. Robust standard errors are adjusted by clustering at the country-time level. Only the coefficients are shown in the table. ${ }^{* * *} p<0.01,{ }^{* *} p<0.05,{ }^{*} p<0.1$. The data span from 1994 to 2010 . See Table C5.

Source: Based on CNEF, ECHP and SILC. 
Table C5. Country coverage in the macro and micro level regressions

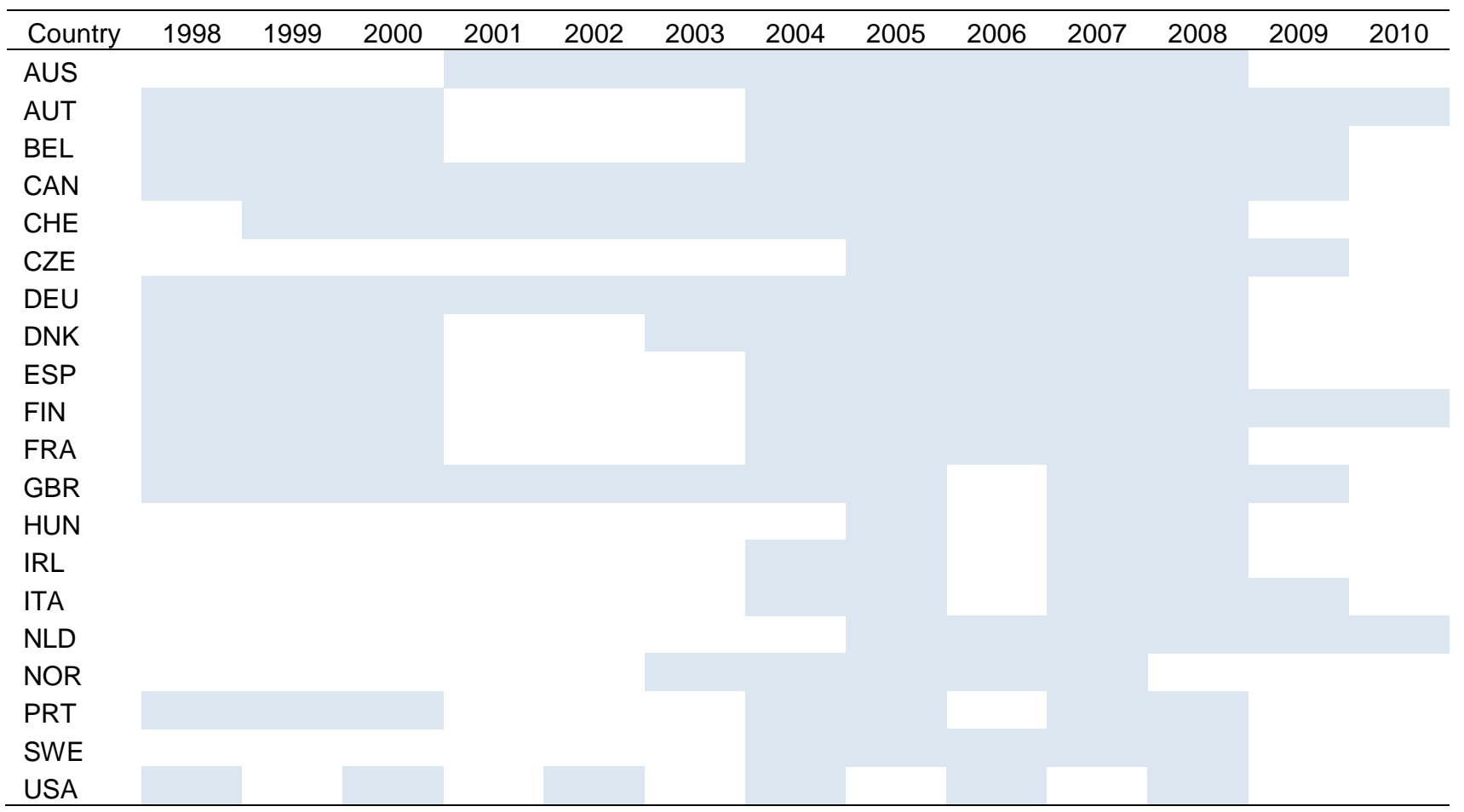

Note: This table shows the effective coverage of country-year in the panel regressions, i.e. after combining survey data (Figure A.1.) and policy indicators. A shaded cell indicates that regressions cover the corresponding country and year. A white cell indicates that the corresponding country and year are not covered for lack of necessary data.

Source: Based on CNEF, ECHP and SILC. 
Table C6. Earnings volatility and economic policies by sectors

\begin{tabular}{|c|c|c|c|c|c|c|c|c|}
\hline \multirow[b]{3}{*}{ VARIABLES } & (1) & (2) & (3) & $(4)$ & (5) & (6) & (7) & (8) \\
\hline & \multicolumn{2}{|c|}{ Annual hours } & \multicolumn{2}{|c|}{ Hourly earnings } & \multicolumn{2}{|c|}{ Annual hours } & \multicolumn{2}{|c|}{ Hourly earnings } \\
\hline & $\begin{array}{c}\text { Incidence } \\
\text { of large } \\
\text { changes }\end{array}$ & $\begin{array}{l}\text { Rolling } \\
\text { window }\end{array}$ & $\begin{array}{c}\text { Incidence } \\
\text { of large } \\
\text { changes }\end{array}$ & $\begin{array}{l}\text { Rolling } \\
\text { window }\end{array}$ & $\begin{array}{c}\text { Incidence } \\
\text { of large } \\
\text { changes }\end{array}$ & $\begin{array}{l}\text { Rolling } \\
\text { window }\end{array}$ & $\begin{array}{c}\text { Incidence } \\
\text { of large } \\
\text { changes }\end{array}$ & $\begin{array}{l}\text { Rolling } \\
\text { window }\end{array}$ \\
\hline USrealloc *EPL & $\begin{array}{c}0.185^{\star \star} \\
(0.0864)\end{array}$ & $\begin{array}{c}0.108 \\
(0.0717)\end{array}$ & $\begin{array}{c}0.169^{*} \\
(0.0905)\end{array}$ & $\begin{array}{c}0.282^{\star \star \star} \\
(0.105)\end{array}$ & & & & \\
\hline USrealloc *EPL^2 & $\begin{array}{c}-0.0402^{* *} \\
(0.0156)\end{array}$ & $\begin{array}{l}-0.0255^{*} \\
(0.0129)\end{array}$ & $\begin{array}{c}-0.0394^{\star *} \\
(0.0163)\end{array}$ & $\begin{array}{c}-0.0470 * * \\
(0.0190)\end{array}$ & & & & \\
\hline USentry *PMR & & & & & $\begin{array}{c}0.101^{*} \\
(0.0540)\end{array}$ & $\begin{array}{c}0.0826^{*} \\
(0.0423)\end{array}$ & $\begin{array}{c}0.0107 \\
(0.0538)\end{array}$ & $\begin{array}{l}-0.133^{* *} \\
(0.0615)\end{array}$ \\
\hline USentry *PMR^2 & & & & & $\begin{array}{l}-0.0256^{*} \\
(0.0144)\end{array}$ & $\begin{array}{l}-0.0220^{*} \\
(0.0113)\end{array}$ & $\begin{array}{r}-0.00369 \\
(0.0143)\end{array}$ & $\begin{array}{l}0.0376^{* *} \\
(0.0164)\end{array}$ \\
\hline Constant & $\begin{array}{l}0.195^{\star * *} \\
(0.0419)\end{array}$ & $\begin{array}{l}0.166^{\star * *} \\
(0.0348)\end{array}$ & $\begin{array}{l}0.250^{\star * *} \\
(0.0439)\end{array}$ & $\begin{array}{l}0.107^{* *} \\
(0.0511)\end{array}$ & $\begin{array}{c}-0.174 \\
(0.183)\end{array}$ & $\begin{array}{c}-0.128 \\
(0.143)\end{array}$ & $\begin{array}{c}0.262 \\
(0.182)\end{array}$ & $\begin{array}{c}0.640^{* * *} \\
(0.208)\end{array}$ \\
\hline Observations & 117 & 117 & 117 & 117 & 135 & 135 & 135 & 135 \\
\hline Number of country & 9 & 9 & 9 & 9 & 9 & 9 & 9 & 9 \\
\hline Adjusted R-squared & 0.655 & 0.553 & 0.650 & 0.609 & 0.612 & 0.547 & 0.614 & 0.588 \\
\hline
\end{tabular}

Notes: ${ }^{* *} \mathrm{p}<0.01,{ }^{* *} \mathrm{p}<0.05,{ }^{*} \mathrm{p}<0.1$. The data span from 1994 to 2000 . USrealloc is defined as the worker reallocation rate in the US industries. USentry is defined as the firm entry rate in the US industries. Country and industry dummies, and dummies for the proportion of male workers and the proportion of workers older than 45 years are included. See Box 4 for details on the identification methodology.

Source: Annual hours worked and hourly earnings derived from household surveys (CNEF and ECHP), worker reallocation rates are from Bassanini et al. (2010), "Institutional Determinants of Worker Flows: A Cross-Country/Cross-Industry Approach", OECD Social, Employment and Migration Working Papers, No. 107, OECD Publishing. Firm entry rates from Klapper et al (2006), "Entry Regulation as a Barrier to Entrepreneurship", Journal of Financial Economics, Vol. 82, No. 3, pp. 591-629. 
Table C7. Distance to growth-volatility frontier and structural policies

\begin{tabular}{lcc}
\hline & $\begin{array}{c}\text { Linear term } \\
\text { coefficient }\end{array}$ & $\begin{array}{c}\text { Squared term } \\
\text { coefficient }\end{array}$ \\
\hline Employment protection & 0.165 & $-0.0195^{\star * *}$ \\
& $(0.138)$ & $(0.00386)$ \\
Spending on ALMP & $-0.0171^{*}$ & $0.00869^{\star *}$ \\
& $(0.00899)$ & $(0.00387)$ \\
Gross replacement rates & $0.0273^{\star *}$ & -0.00299 \\
& $(0.0116)$ & $(0.00435)$ \\
Centralisation of wage bargaining & $0.0342^{\star *}$ & $-0.0112^{\star *}$ \\
& $(0.0143)$ & $(0.00475)$ \\
Credit intermediation ratio & 0.000461 & $0.00526^{*}$ \\
& $(0.0119)$ & $(0.00295)$ \\
Product market regulation & -0.00941 & 0.00117 \\
& $(0.00637)$ & $(0.000968)$ \\
\hline
\end{tabular}

Note: All policy indicators are standardised and centred. Estimation based on a sample of 173 observations across 21 countries. Time-fixed and country-fixed effects are included. Robust standard errors in parentheses ${ }^{* * *} p<0.01,{ }^{* *} p<0.05,{ }^{*} p<0.1$.

Source: OECD calculations using CNEF, ECHP and EU-SILC and OECD statistics. 
ECO/WKP(2015)19

\section{BIBLIOGRAPHY}

Acemoglu, D., V. M. Carvalho, A. Ozdaglar and A. Tahbaz-Salehi (2012), "The Network Origins of Aggregate Fluctuations", Econometrica, Vol. 80, No. 5, pp. 1977-2016.

Aghion, P. and R. Griffith (2008), "Competition and Growth: Reconciling Theory and Evidence", Zeuthen Lectures, MIT Press: Cambridge, US.

Aghion, P. and P. Howitt (1992), "A Model of Growth through Creative Destruction”, Econometrica, Vol. 60, No. 2, pp. 323-351.

Andrews, D. and F. Cingano (2012), "Public Policy and Resource Allocation: Evidence from Firms in OECD Countries", OECD Economics Department Working Papers, No. 996, OECD Publishing.

Bartelsman, E. J., P. A. Gautier and J. De Wind (2013), "Employment Protection, Technology Choice, and Worker Allocation", The Quarterly Journal of Economics, Vol. 128, No. 1, pp. 249-85.

Bassanini, A., A. Garnero, P. Marianna and S.J. Martin (2010), "Institutional Determinants of Worker Flows: A Cross-Country/Cross-Industry Approach", OECD Social, Employment and Migration Working Papers, No. 107, OECD Publishing.

Bassanini, A. and A. Garnero (2013), "Dismissal Protection and Worker Flows in OECD Countries: Evidence from Cross-Country/Cross-Industry Data", Labour Economics, Vol. 21, pp. 25-41.

Bassanini, A. and R. Duval (2006), "Unemployment, Institutions and Reform Complementarities: Reassessing the Aggregate Evidence for OECD Countries", Oxford Review of Economic Policy, 25(1), pp. 40-59.

Brunnermeier, M. and Y. Sannikov (2014), "A Macro-Model with a Financial Sector", American Economic Review, Vol. 104, No. 2, pp. 379-421.

Buch, C. M., J. Döpke and H. Strotmann (2009), "Does Export Openness Increase Firm-level Output Volatility?", The World Economy, Vol. 32, No. 4, pp. 531-551.

Carvalho, V. M. and X. Gabaix (2013), "The Great Diversification and its Undoing”, American Economic Review, Vol. 103, No. 5, pp. 1697-1727.

Comin, D., E. L. Groshen and B. Rabin (2009), "Turbulent Firms, Turbulent Wages?", Journal of Monetary Economics, Vol. 56, No. 1, pp. 109-133.

Comin, D. and S. Mulani (2009), "A Theory of Growth and Volatility at the Aggregate and Firm Level", Journal of Monetary Economics, Vol. 56, No. 8, pp. 1023-1042. 


\section{ECO/WKP(2015)19}

Cournède, B., A. Goujard and A. Pina (2014), "Reconciling Fiscal Consolidation with Growth and Equity," OECD Economic Studies, Vol. 2013. Issue 1, OECD Publishing.

Cournède, B. and O. Denk (2015), "Finance and Economic Growth in OECD and G20 Countries," OECD Economics Department Working Papers, forthcoming.

Creedy, J. and M. Wilhelm (2002), "Income Mobility, Inequality and Social Welfare”, Australian Economic Papers, 41(2), pp. 140-150.

Davis, S. J. and J. A. Kahn (2008), "Interpreting the Great Moderation: Changes in the Volatility of Economic Activity at the Macro and Micro Levels", The Journal of Economic Perspectives, Vol. 22, No. 4, pp. 155-180.

Elsby, M. W., D. Shin and G. Solon (2013), "Wage Adjustment in the Great Recession", NBER Working Paper, No. 19478.

Fehr, E. and L. Goette (2005), "Robustness and Real Consequences of Nominal Wage Rigidity", Journal of Monetary Economics, Vol. 52, No. 4, pp. 779-804.

Garcia-Vega, M., A. Guariglia and M. E. Spaliara (2012), "Volatility, Financial Constraints, and Trade", International Review of Economics and Finance, Vol. 21, No. 1, pp. 57-76.

Garda, P. and V. Ziemann (2014), "Economic Policies and Microeconomic Stability: A Literature Review and Some Empirics", OECD Economics Department Working Papers, No. 1115, OECD Publishing.

Hoeller, P., I. Joumard and I. Koske (eds.) (2014), Income Inequality in OECD Countries: What Are the Drivers and Policy Options?, World Scientific Publishing.

Holden, S. (2004), "The Costs of Price Stability: Downward Nominal Wage Rigidity in Europe", Economica, Vol. 71, No. 282, pp. 183-208.

Kelly, B., H. Lustig and S. Van Nieuwerburgh (2013), "Firm Volatility in Granular Networks", FamaMiller Working Paper; Chicago Booth Research Paper, No. 12-56.

Klapper, L., Laeven, L. and R. Rajan (2006), "Entry Regulation as a Barrier to Entrepreneurship”, Journal of Financial Economics, Vol. 82, No. 3, pp. 591-629.

Korinek, A. and J. Kreamer (2013), "The Redistributive Effects of Financial Deregulation", NBER Working Paper, No. 19572.

Lindbeck, A. and Snower, D. J. (1986), "Wage Setting, Unemployment, and Insider-Outsider Relations", The American Economic Review, Vol. 76, No. 2, pp. 235-239.

Nickell, S. and G. Quintini (2003), "Nominal Wage Rigidity and the Rate of Inflation", The Economic Journal, Vol. 113, No. 490, pp. 762-781.

OECD (2004), "Wage-Setting Institutions and Outcomes," Chapter 3, OECD Employment Outlook, OECD Publishing.

OECD (2010), "Institutional and Policy Determinants of Labour Market Flows", in OECD Employment Outlook 2010: Moving beyond the Jobs Crisis, OECD Publishing. 
OECD (2012), “What Makes Labour Markets Resilient During Recessions?”, in OECD Employment Outlook 2012, OECD Publishing.

OECD (2013a), How's Life? 2013: Measuring Well-being, OECD Publishing.

OECD (2013b), Economic Policy Reforms 2013: Going for Growth, OECD Publishing.

OECD (2015), Economic Policy Reforms 2015: Going for Growth, OECD Publishing.

Ohanian, L. E. and A. Raffo (2011), "Aggregate Hours Worked in OECD Countries: New Measurement and Implications for Business Cycles", NBER Working Paper, No. 17420.

Petrongolo, B. and C. Pissarides (2008), "The Ins and Outs of European Unemployment", American Economic Review Papers and Proceedings, Vol. 98, No. 2, pp. 256-262.

Poschke, M. (2009), "Employment Protection, Firm Selection, and Growth.", Journal of Monetary Economics, Vol. 56, No. 8, pp. 1074-1085.

Rajan, R. G. and L. Zingales (1998), "Financial Dependence and Growth", American Economic Review, 88(3), pp. 559-586.

Sutherland, D., P. Hoeller, R. Merola and V. Ziemann, (2012), "Debt and Macroeconomic Stability", OECD Economics Department Working Papers, No. 1003, OECD Publishing.

Sutherland, D. and P. Hoeller (2013), "Growth-promoting Policies and Macroeconomic Stability", OECD Economics Department Working Papers, No. 1091, OECD Publishing.

Vannoorenberghe, G. (2012), "Firm-Level Volatility and Exports", Journal of International Economics, Vol. 86, No. 1, pp. 57-67.

von Wachter, T., and S. Davis (2011), "Recessions and the Costs of Job Loss", Brookings Papers on Economic Activity.

Zeliak, J. P., B. Hardy and C. Bollinger (2010), "Earnings and Income Volatility in America: Evidence from Matched CPS," University of Kentucky Center for Policy Research Discussion Paper Series, No. 2010-05.

Ziemann, V. (2013), "Do Structural Policies Affect Macroeconomic Stability?", OECD Economics Department Working Papers, No. 1075, OECD Publishing. 


\section{WORKING PAPERS}

The full series of Economics Department Working Papers can be consulted at www.oecd.org/eco/workingpapers

1200. The 2013 update of the OECD's database on product market regulation - policy insights for $O E C D$ and non-OECD countries

(April 2015) by Isabell Koske, Isabelle Wanner, Rosamaria Bitetti and Omar Barbiero

1199. Improving taxes and transfers in Australia

(April 2015) by Philip Hemmings and Annamaria Tuske

1198. Federal-state relations in Australia

(April 2015) by Vassiliki Koutsogeorgopoulou and Annamaria Tuske

1197. Sharing the fruits of growth in Mexico

(April 2015) by Eduardo Olaberriá and Valéry Dugain

1196. What makes Mexican's happy?

(April 2015) by Valéry Dugain and Eduardo Olaberriá

1195. Improving the labour market integration of immigrants in Belgium

(March 2015) by Álvaro Pina, Vincent Corluy and Gerlinde Verbist

1194. Raising the potential of the domestically oriented sector in Germany

(March 2015) by André Eid and Andrés Hutfilter

1193. Improving transport infrastructure in Russia

(March 2015) by Alexander Kolik, Artur Radziwill and Natalia Turdyeva

1192. Improving the business climate in Russia

(March 2015) by Arthur Radziwill and Yana Vaziakova

1191. Determinants of female entrepreneurship in India

(March 2015) by Arnaud Daymard

1190. The changing role of the exchange rate for macroeconomic adjustment

(March 2015) by Patrice Ollivaud, Elena Rusticelli and Cyrille Schwellnus

1189. Boosting productivity in Russia: skills, education and innovation

(March 2015) by Lilas Demmou and Andreas Wörgötter

1188. Boosting growth and reducing informality in Mexico

(March 2015) by Sean Dougherty

1187. The conduct of monetary policy in the future: instrument use

(March 2015) by Kei-Ichiro Inaba, Rory O'Farrell, Łukasz Rawdanowicz and Ane Kathrine Christensen

1186. A constant market share analysis of Spanish goods

(February 2015) by Alberto Gonzalez Pandiella 
1185. Raising the economic participation of women in India - a new growth engine?

(February 2015) by Piritta Sorsa

1184. Improving health outcomes and health care in India

(January 2015) by Isabelle Joumard and Ankit Kumar

1183. Challenges and opportunities of India's manufacturing sector

(January 2015) by Isabelle Joumard, Urban Sila and Hermes Morgavi

1182. The heterogeneity of product market regulations

(December 2014) by Jean-Marc Fournier

1181. Implicit regulatory barriers in the EU single market: new empirical evidence from gravity models

(December 2014) by Jean-Marc Fournier, Aurore Domps, Yaëlle Gorin, Xavier Guillet and Délia Morchoisne

1180. Can pro-growth policies lift all boats? An analysis based on household disposable income (December 2014) by Orsetta Causa, Alain de Serres and Nicolas Ruiz

1179. Empirical evidence on the effects of environmental policy stringency on productivity growth (December 2014) by Silvia Albrizio, Tomasz Koźluk and Vera Zipperer

1178. The Indicators of the Economic Burdens of Environmental Policy Design - Results from the OECD Questionnaire

(December 2014) by Tomasz Koźluk

1177. Measuring Environmental Policy Stringency in OECD Countries-A Composite Index Approach (December 2014) by Enrico Botta and Tomasz Koźluk

1176. Do Environmental Policies Matter for Productivity Growth? Insights from new Cross-Country Measures of Environmental Policies

(December 2014) by Silvia Albrizio, Enrico Botta, Tomasz Koźluk and Vera Zipperer

1175. Making economic growth more socially inclusive

(December 2014) by Andrés Fuentes Hutfilter and Andreas Kappeler

1174. New tax and expenditure elasticity estimates for EU budget surveillance

(December 2014) by Robert W.R. Price, Thai-Thanh Dang and Yvan Guillemette

1173. Moving towards a more dynamic business sector in Spain

(November 2014) by Alberto Gonzalez Pandiella

1172. Better harnessing talent and knowledge to boost sustainable medium-growth in Spain

(November 2014) by David Haugh and Ben Westmore

1171. The internet economy - regulatory challenges and practices

(November 2014) by Isabell Koske, Rosamaria Bitetti, Isabelle Wanner and Ewan Sutherland

1170. A revival of the private rental sector of the housing market? Lessons from Germany, Finland, the Czech Republic and the Netherlands

(October 2014) by Rik de Boer and Rosamaria Bitetti 